Universidade de São Paulo

Escola Superior de Agricultura "Luiz de Queiroz"

Análise de seqüências expressas em raízes de cana-de-açúcar colonizadas por Glomus clarum

\title{
Daniele Takahashi
}

Tese apresentada para obtenção do título de Doutor em Agronomia. Área de concentração: Microbiologia Agrícola

Piracicaba

2005 
Daniele Takahashi

Engenheiro Agrônomo

Análise de seqüências expressas em raízes de cana-de-açúcar colonizadas por Glomus clarum

Orientador:

Prof. Dr. MARCIO RODRIGUES LAMBAIS

Tese apresentada para obtenção do título de Doutor em

Agronomia. Área de concentração: Microbiologia Agrícola

\section{Piracicaba}

2005 
Dados Internacionais de Catalogação na Publicação (CIP) DIVISÃO DE BIBLIOTECA E DOCUMENTAÇÃO - ESALQ/USP

\section{Takahashi, Daniele}

Análise de seqüência expressas em raízes de cana-de-açúcar colonizadas por Glomus clarum Daniele Takahashi. - - Piracicaba, 2005.

117 p. : il.

Tese (Doutorado) - - Escola Superior de Agricultura Luiz de Queiroz, 2005. Bibliografia.

1. Cana-de-açúcar 2. Fungo micorrizico 3. Raiz 4. Seqüênciamento genético I. Título

CDD 633.61 


\section{DEDICATÓRIA}

Dedico este trabalho à minha família. Ao Denis e ao nosso futuro.

“...então (os problemas) finalmente atacam. Sua Alegria, Prudência e Coragem, além de sua firme Fé no Sutra de Lótus farão com que você sobreviva ileso.

Nitiren Daishonin, monge budista 


\section{AGRADECIMENTOS}

Ao Prof. Dr. Marcio Rodrigues Lambais pela oportunidade de realização deste projeto, pela segura orientação e pela confiança depositada.

À CAPES pela bolsa concedida e à FAPESP pelo financiamento do projeto.

À Coordenação do PPG Microbiologia Agrícola e à ESALQ pela oportunidade da realização do doutorado.

Aos colegas do Laboratório de Microbiologia Molecular: Carolina, Gisele, Hélio, Juliano, Lucas, Marcio, Pablo, Rafael, Robinson, Simão e Soraya pela amizade e momentos inesquecíveis.

Aos técnicos do Laboratório de Microbiologia de Solos: Denise e Fernando pelo apoio na condução dos experimentos.

À Profa. Dra. Helaine Carrer, pela permissão do uso das instalações do CEBTEC para o seqüenciamento das amostras. E, especialmente, à toda equipe: Valesca, Adriano, Henrique, Danila e à técnica Fátima pelo apoio e amizade.

Ao Prof. Dr. Luiz L. Coutinho, pela permissão do uso das instalações do Laboratório de Biotecnologia Animal para os trabalhos com radioatividade e para o seqüenciamento das amostras. E, especialmente, à sua equipe: a técnica Nirlei e as alunas Lilian, Clarissa, Carla e Érica pela valiosa colaboração durante a condução dos experimentos.

Aos colegas Ricardo e Mateus pela implementação dos procedimentos para a análise de bioinformática.

À Jerusa por sua contribuição nas extrações de plasmídeos.

À BSGI (Brasil-Soka Gakkai Internacional) pelos valiosos ensinamentos budistas que me foram ensinados.

À minha família. Meu pai e meu irmão Henry que me apóiam apesar da grande distância que nos separa. E à minha mãe e ao meu irmão Felipe que aprenderam a conviver com as loucuras da vida acadêmica.

Ao Denis pela companhia nestes tempos tão difíceis. 


\section{SUMÁRIO}

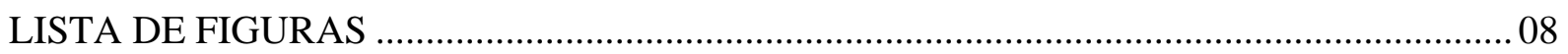

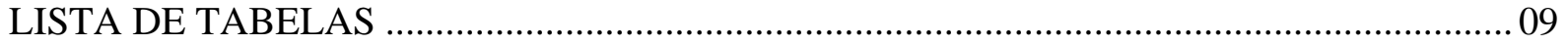

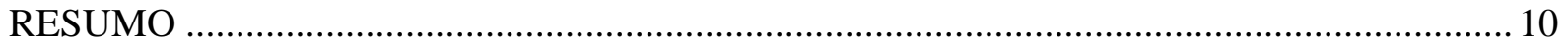

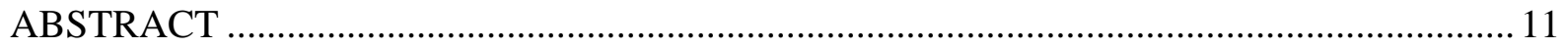

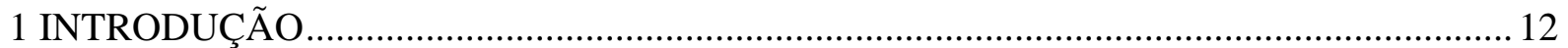

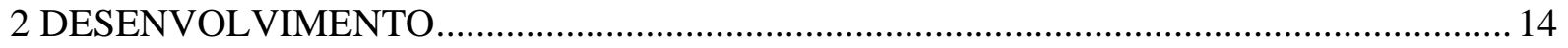

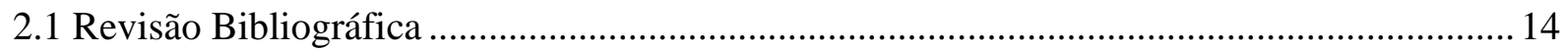

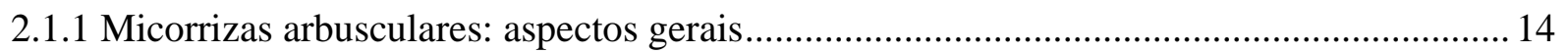

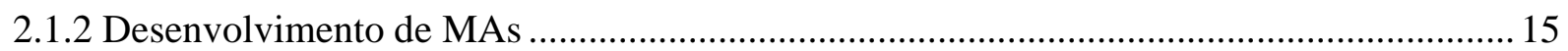

2.1.3 Expressão diferencial de genes em MAs e as ferramentas de estudo.................................. 17

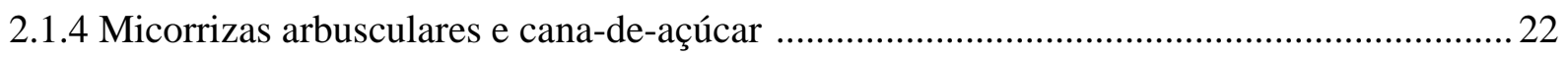

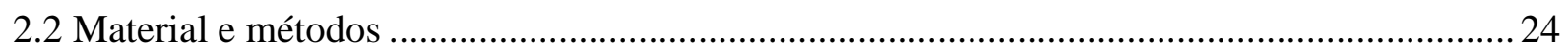

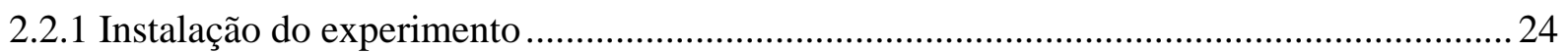

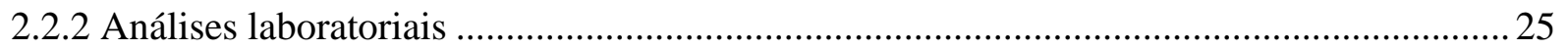

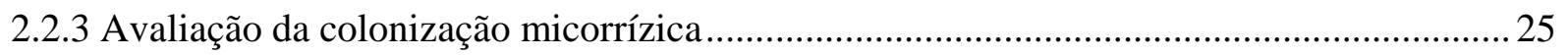

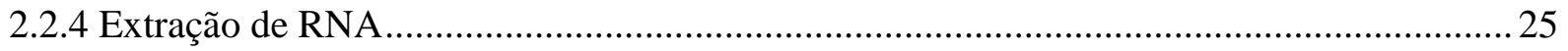

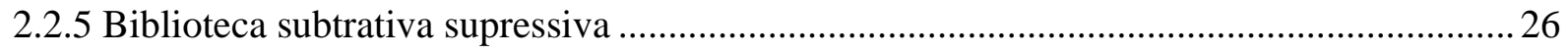

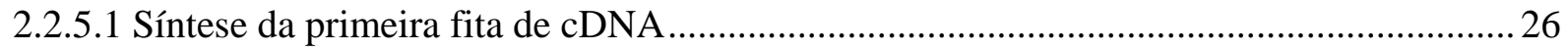

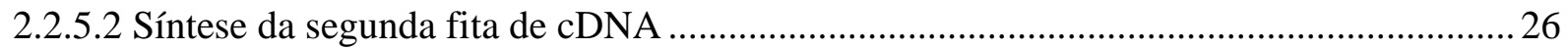

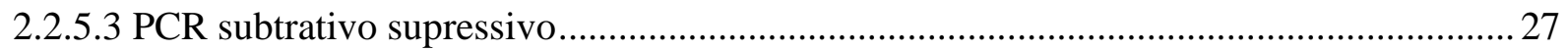

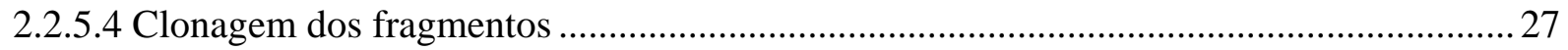

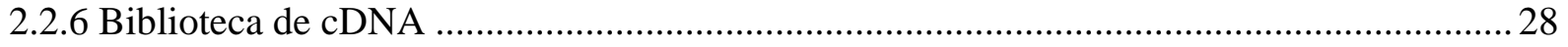

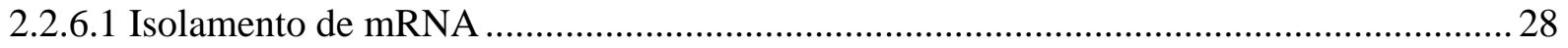

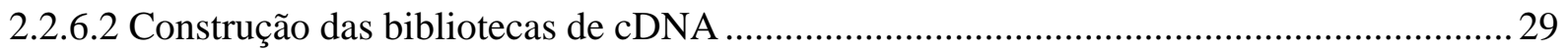

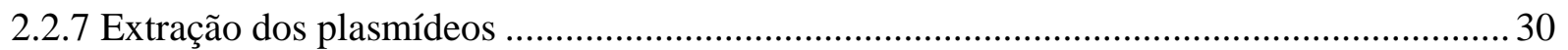

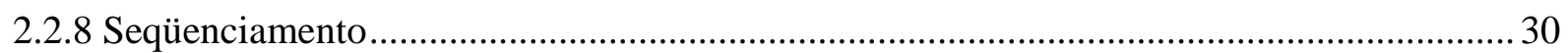

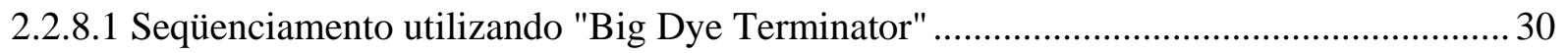

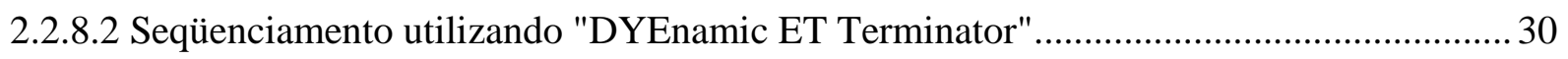

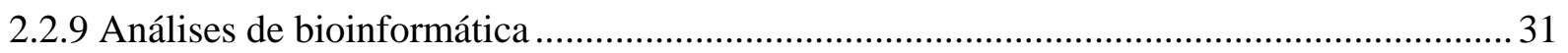


2.2.10 Análise de expressão in silico. 31

2.2.11 Análise de expressão em macroarranjos de cDNA ........................................................... 32

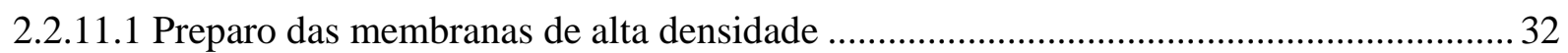

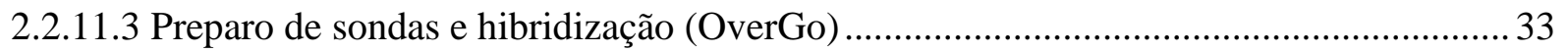

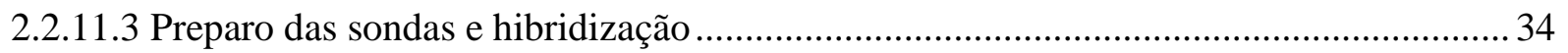

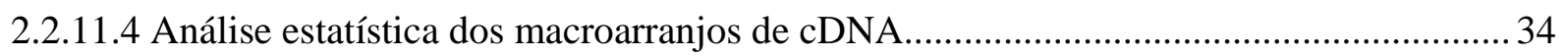

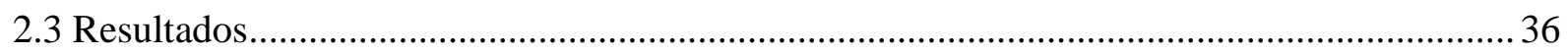

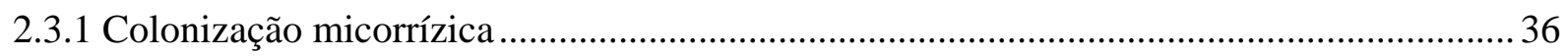

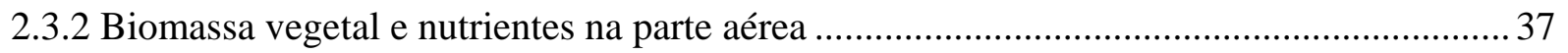

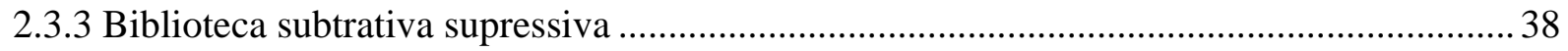

2.3.3.1 Construção de biblioteca subtrativa supressiva ................................................................ 38

2.3.3.2 Descrição da biblioteca subtrativa supressiva .................................................................... 38

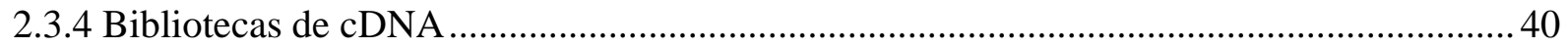

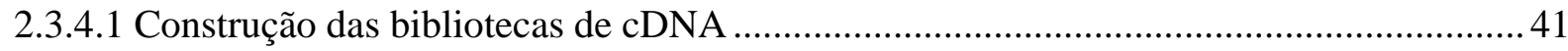

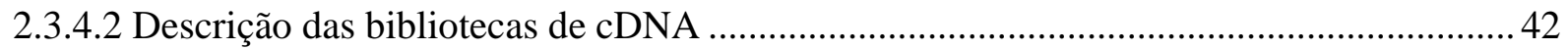

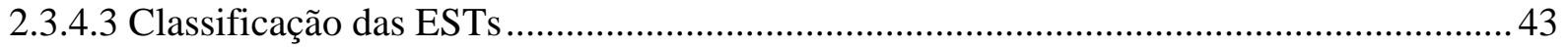

2.3.5 Analise de expressão gênica em Northern blot eletrônico .................................................. 46

2.3.6 Análise de expressão gênica em macroarranjos de cDNA ….............................................. 49

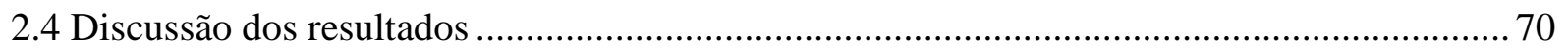

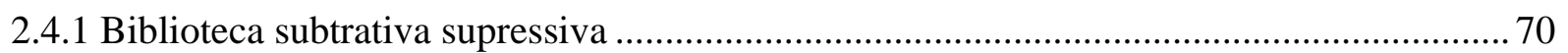

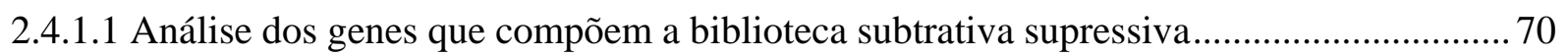

2.4.1.2 Análise de expressão diferencial em macroarranjos dos genes provenientes da

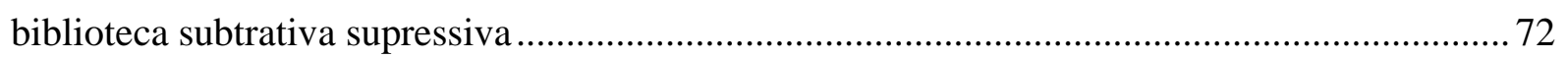

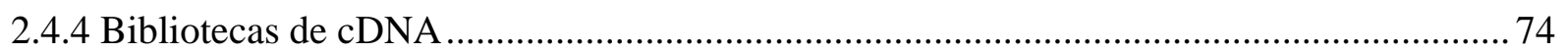

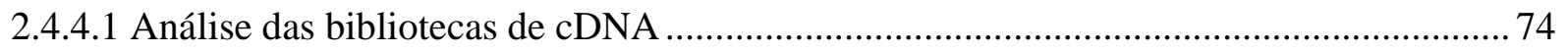

2.4.4.2.Análise da expressão gênica em Northern blot eletrônico ............................................... 75

2.4.5 Análise de expressão diferencial em macroarranjos........................................................... 76

2.4.5.1 Genes que codificam reguladores de transcrição ............................................................. 76

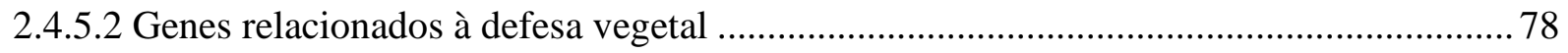

2.4.5.3 Genes relacionados à formação de parede celular e membranas....................................... 79

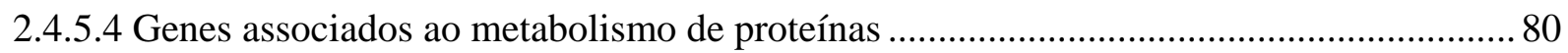


2.4.5.5 Genes codificando componentes das vias de transdução de sinais .82

2.4.5.6 Genes indicadores do processo de colonização intrarradicular. 84

2.4.6 Possíveis mecanismos de regulação gênica durante o desenvolvimento de MAs. 84

3 CONCLUSÕES . .87

REFERÊNCIAS 88 


\section{LISTA DE FIGURAS}

Figura 1 - Porcentagem de colonização micorrizica em raízes de cana-de-açúcar inoculadas com Glomus clarum (Gc) e cultivadas com 20 (PB) ou 200 (PA) mg P kg-1 de substrato. As plantas foram colhidas 8 ou 12 semanas após o transplantio (SAT) ... 35

Figura 2 - Eletroforese dos cDNAs de raízes de cana-de-açúcar de diferentes tratamentos em gel de agarose $1,0 \%$

Figura 3 - Etapas para a construção de bibliotecas de cDNA

Figura 4 - Freqüência relativa de clusters com diferentes números de ESTs.

Figura 5 - Categorização das seqüências identificadas nas bibliotecas de cDNAs. Distribuição das porcentagens de freqüência nas 20 categorias propostas neste estudo.

Figura 6 - Perfil de expressão in silico de ESTs isoladas de raízes de cana-de-açúcar inoculadas com Glomus clarum e cultivadas com 20 (PB) ou 200 (PA) mg P kg-1 de substrato.

Figura 7 - Relação entre a variação das razões e intensidades de expressão entre raízes colonizadas por Glomus clarum e controles não-inoculados, cultivados em baixo $\mathrm{P}(\mathrm{PBG} / \mathrm{PBNi})$.

Figura 8 - Relação entre a variação das razões e intensidades de expressão entre raízes colonizadas por Glomus clarum e controles não-inoculados, cultivados em alto P (PAGc/PANi)

Figura 9 - Relação entre a variação das razões e intensidades de expressão entre raízes nãoinoculadas, cultivadas em condições de alto ou baixo P (PANi/PBNi).

Figura 10 - Relação entre a variação das razões e intensidades de expressão entre raízes colonizadas, cultivadas em alto P ou baixo P (PAGc/PBGc).

Figura 11 - Relação entre a variação das razões e intensidades de expressão entre raízes nãoinoculadas, cultivadas em alto $\mathrm{P}$ e raízes colonizadas cultivadas em baixo $\mathrm{P}$ (PANi/PBGc)

Figura 12 - Freqüência de genes de diferentes categorias com expressão diferencial significativa $(\mathrm{p}<0,05)$ determinada por hibridização com macroarranjos de cDNAs, e dos genes utilizados para a confecção de macroarranjos de cDNAs ......... 


\section{LISTA DE TABELAS}

Tabela 1 - Biomassa aérea e concentração de nutrientes na parte aérea de plantas de canade-açúcar, não-inoculadas (Ni) ou inoculadas com o fungo G. clarum (Gc)e cultivadas durante 8 semanas em vasos contendo $20 \mathrm{mg} \mathrm{P} \mathrm{kg}^{-1}$ (PB) ou $200 \mathrm{mg}$

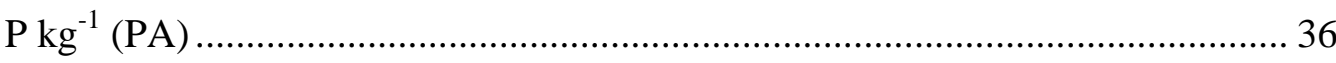

Tabela 2 - Biomassa aérea e concentração de nutrientes na parte aérea de plantas de canade-açúcar, não-inoculadas (Ni) ou inoculadas com o fungo G. clarum (Gc)e cultivadas durante 12 semanas em vasos contendo $20 \mathrm{mg} \mathrm{P} \mathrm{kg}^{-1}$ (PB) ou 200 $\mathrm{mg} \mathrm{P} \mathrm{kg}^{-1}$ (PA)

Tabela 3 - Quantidade e qualidade do RNA total utilizado para a construção das bibliotecas de cDNA

Tabela 4 - Características das bibliotecas de cDNA sintetizadas. 43

Tabela 5 - Genes com expressão diferencial em raízes colonizadas por Glomus clarum e cultivadas em $20 \mathrm{mg} \mathrm{P} \mathrm{kg}^{-1}$ comparadas com raízes não-inoculadas e cultivadas em 20 mg $P \mathrm{~kg}^{-1}$

Tabela 6 - Genes com expressão diferencial em raízes colonizadas por Glomus clarum e cultivadas em $200 \mathrm{mg} \mathrm{P} \mathrm{kg}^{-1}$ comparadas com raízes não-inoculadas cultivadas em 200 mg $\mathrm{P} \mathrm{kg}{ }^{-1}$ 56

Tabela 7 - Genes com expressão diferencial em raízes não-inoculadas e cultivadas em 200 mg P kg${ }^{-1}$ comparadas com raízes não-inoculadas e cultivadas em 20 mg P kg-1 59

Tabela 8 - Genes com expressão diferencial em raízes colonizadas por Glomus clarum e cultivadas em $200 \mathrm{mg} \mathrm{P} \mathrm{kg}{ }^{-1}$ comparadas com raízes colonizadas por Glomus clarum e cultivadas em $20 \mathrm{mg} \mathrm{P} \mathrm{kg}^{-1}$....

Tabela 9 - Genes com expressão diferencial em raízes não-inoculadas e cultivadas em 200 mg $\mathrm{P} \mathrm{kg}^{-1}$ comparadas com raízes colonizadas por Glomus clarum e cultivadas em 20 mg $P k g^{-1}$ 


\section{RESUMO}

\section{Análise de seqüências expressas em raízes de cana-de-açúcar colonizadas por Glomus}

\section{clarum}

A formação de micorrizas arbusculares é um processo regulado geneticamente e envolve alterações da expressão gênica da planta e do fungo. Poucos genes essenciais para o desenvolvimento da simbiose foram identificados até o presente. Para identificar genes possivelmente envolvidos no controle da colonização fúngica intrarradicular, o perfil de seqüências expressas em raízes de cana-de-açúcar colonizadas por Glomus clarum, em condições de baixo e alto fósforo (P), foi avaliado através do seqüenciamento em larga escala de ESTs e hibridização em macroarranjos de cDNAs. Plântulas micropropagadas de cana-de-açúcar foram plantadas em vasos contendo substrato composto por areia:vermiculita (3:1, vol/vol) e adubado com 20 ou $200 \mathrm{mg} \mathrm{P} \mathrm{kg}^{-1}$ de substrato e inoculadas com Glomus clarum. A biomassa seca da parte aérea e a taxa de colonização micorrízica das raízes foram avaliadas no momento da colheita que foi feita oito ou doze semanas após o plantio. O RNA poliA foi extraído das raízes e utilizado para a síntese de cDNAs. Neste trabalho, quatro bibliotecas de cDNA e uma biblioteca subtrativa supressiva foram preparadas a partir de cDNAs de raízes de cana-de-açúcar colonizadas por G. clarum. Esta abordagem resultou na identificação de 1,925 ESTs as quais foram agrupadas em 1615 genes supostamente regulados pela micorrização. Estes clones foram analisados por Northern blots eletrônico, e aqueles que foram diferencialmente expressos foram submetidos a hibridização em macroarranjos de cDNAs. Um total de 386 genes foram arranjados em membranas de náilon e sua expressão avaliada por sondas sintetizadas a partir de cDNA extraído de raízes em diferentes condições. Dentre os genes com expressão diferencial significativa estatística em raízes colonizadas por G. clarum, em condições de baixo e alto P, foram detectados genes codificando proteínas putativamente envolvidas na percepção de moléculas sinais (receptor tipo quinase de proteína), transporte de íons (canais de íons), transdução de sinais (quinases de proteína e calmodulina), regulação da transcrição (fatores de transcrição), alterações de parede celular e citoesqueleto (extensina, arabinogalactanas, tubulinas), respostas de defesa e estresse (síntese de fitoalexinas e metalotioneínas), síntese de fitohormônios (nitrilase). Os dados sugerem que a transdução de sinais em MAs se dá através da fosforilação de proteínas e que a indução de respostas anti-oxidantes pode ser importante para o desenvolvimento da simbiose. Da mesma forma, os dados sugerem que a atividade de aspartatoproteases podem ser essenciais para o controle do crescimento fúngico intrarradicular. A caracterização desses genes e seus padrões de expressão em MAs poderá elucidar os mecanismos genéticos envolvidos no controle da simbiose.

Palavras-chave: Micorrizas arbusculares; Saccharum spp.; Seqüenciamento 


\section{ABSTRACT \\ Expressed sequences analisys from sugarcane roots colonized with Glomus clarum}

The formation of arbuscular mycorrhizae (AM) is a genetically regulated process and involves alteration in both plant and fungus gene expression. Few genes essential for the development of the symbioses have been identified so far. In order to identify genes possible involved in the intraradical fungal colonization control, the profiles of expressed sequences in sugarcane roots colonized roots with Glomus clarum at low or high phosphate (P) conditions were evaluated using large scale EST sequencing and cDNA macroarray hybridization. Sugarcane micropropagated seedlings were planted in pots containing sand:vermiculite (3:1, vol:vol), and fertilized with 20 or $200 \mathrm{mg} \mathrm{P} \mathrm{kg}^{-1}$ substrate. Seedlings were inoculated with $G$. clarum and cultivated under greenhouse conditions for 8 or 12 weeks. After harvesting shoot dry weight and root colonization rates were evaluated. PolyA RNA was extracted from the root tissues and used for cDNA synthesis. In this work, one suppressive subtractive library and four cDNA libraries were synthesized using cDNA from sugarcane roots not-colonized or colonized by G. clarum, at low and high P conditions. This approach resulted in the identification of 1,925 ESTs which were clustered in 1,615 genes. The expression of these genes was evaluated using electronic Northern blots. A total of 386 genes with putative differential expression were spotted into nylon membranes in macroarrays and their expression profiles in roots under different conditions were evaluated using macroarray hybridization. Among the genes with statistically significant differential expression, in roots colonized by $G$. clarum grown at low or high $\mathrm{P}$ conditions, it was detected genes encoding proteins putatively involved in the perception of signal molecules (receptor-like protein kinase), ion transporte (channel-like protein precursor), signal transduction (protein kinases and calmodulin), transcriptional regulation (transcription factor), cell wall and cytoskeleton alterations (extensin, arabinogalactans, and tubulins), defense and stress responses (phythoalexins synthesis and metalothioneins), and phytohormone biosynthesis (nitrilases). Our data suggest that the signal transduction in AM occurs through protein phosphorylation, and that the induction of anti-oxidant responses may be important for the development of the symbioses. Additionally, the data suggest that aspartic-proteases might be essential for the control of intraradical fungal growth. Further characterization of these genes and their expression patterns in AM would contribute to elucidate the genetic mechanisms controlling the symbioses.

Keywords: Arbuscular mycorrhiza; Saccharum spp.; Sequency 


\section{INTRODUÇÃO}

A cana-de-açúcar é uma cultura de grande importância econômica para o agronegócio brasileiro. Os principais produtos derivados da cana-de-açúcar são: o etanol, utilizado como combustível em veículos automotores em substituição aos derivados de petróleo, e o açúcar, utilizado na alimentação humana. O Brasil é o maior produtor mundial de etanol de cana-deaçúcar e responsável por $60 \%$ da produção mundial de açúcar.

As variedades modernas de cana-de-açúcar foram obtidas através de cruzamentos entre espécies dentro do gênero Saccharum, sendo que o qual é caracterizado pela alta poliploidia e freqüente aneuploidia. Essa variação de ploidia torna os programas de melhoramento genético clássicos baseados em cruzamentos extremamente complexos.

Para desvendar o complexo genoma da cana-de-açúcar, o consórcio ONSA (Organization for Nucleotide Sequencing and Analysis) financiado pela FAPESP iniciou em Setembro de 1998 o projeto SUCEST (Sugarcane Expressed Sequence Tag), gerando um banco de dados contendo 238.000 ESTs (Expressed Sequence Tags) provenientes de 26 bibliotecas de cDNAs, sintetizadas a partir de diversos órgãos e tecidos da cana-de-açúcar em diferentes estádios de desenvolvimento (Arruda, 2001).

A existência de um banco de dados sobre o genoma da cana-de-açúcar pode auxiliar nos estudos de fisiologia vegetal relacionados com as interações simbióticas entre plantas e microrganismos. Dentre as interações simbióticas formadas pela cana-de-açúcar, as micorrizas arbusculares (MAs) possuem importância destacada pois podem aumentar a absorção de P de solos distróficos.

O desenvolvimento de MAs é um processo complexo, controlado pelas interações do genoma da planta e do fungo, e influenciado pelas condições edafoclimáticas. Diversas alterações fisiológicas são observadas nos simbiontes durante o desenvolvimento de uma MA funcional. No entanto, o estudo dos mecanismos responsáveis pela regulação do desenvolvimento de MAs é dificultado pelo fato dos fungos micorrízicos arbusculares (FMAs) serem biotróficos obrigatórios, e o cultivo in vitro das MAs não ser possível.

Recentemente, técnicas de seqüenciamento em larga escala do transcritoma de células ou tecidos vegetais têm sido desenvolvidas para a identificação de genes importantes para a diferenciação celular, respostas a estresse e controle de interações planta microrganismos. 
Diversos trabalhos têm mostrado a ocorrência de genes com expressão diferencial em MAs, mas os mecanismos que controlam essa simbiose ainda permanecem obscuros.

O objetivo deste trabalho foi identificar genes com expressão diferencial em MAs, sob duas concentrações de $\mathrm{P}$ no substrato de cultivo, através da análise dos transcritomas de raízes de cana-de-açúcar colonizadas por Glomus clarum utilizando seqüenciamentos de ESTs e hibridização em macroarranjos de cDNAs. 


\section{DESENVOLVIMENTO}

\subsection{Revisão bibliográfica}

\subsubsection{Micorrizas arbusculares: aspectos gerais}

A capacidade das raízes de plantas estabelecerem relações simbióticas mutualísticas com certos fungos do solo é um fenômeno generalizado na natureza. Essas relações são conhecidas como micorrizas (Silveira, 1992). Mais de 6.000 espécies de fungos do solo são capazes de formar micorrizas com 240.000 espécies de plantas (Bonfante-Fasolo \& Perotto, 1992).

Com base nas características morfológicas e anatômicas, os diferentes tipos de micorrizas podem ser divididos em três grandes grupos: ectomicorrizas, endomicorrizas e ectendomicorrizas. As endomicorrizas são as mais abundantes e compreendem as ericóides, as orquidóides e as arbusculares (Silveira, 1992).

As micorrizas arbusculares (MAs) formadas entre as raízes da maioria das plantas vasculares e fungos da ordem Glomales (Zigomicetos) são as associações simbióticas mutualísticas mais abundantes na natureza (Blilou et al., 2000; Harrison, 1999). Trabalhos recentes sobre a filogenia de fungos micorrízicos arbusculares (FMAs) lançou bases para uma nova classificação sistemática destes fungos, inserindo-os em um novo grupo monofilético denominado Glomeromycota (Schüßler et al., 2001).

Os FMAs são simbiontes obrigatórios de mais de $80 \%$ das plantas vasculares, na maioria dos ecossistemas (Ginzberg et al., 1998). A presença generalizada das MAs nos mais diferentes ambientes é, provavelmente, resultado da ausência de especificidade e de co-evolução dos simbiontes (Cardoso \& Lambais, 1992). Nas MAs, as raízes das plantas são invadidas pelas hifas dos FMAs, os quais colonizam intercelularmente o tecido cortical e diferenciam-se intracelularmente em estruturas típicas chamadas arbúsculos (Bonfante-Fasolo, 1984).

As raízes colonizadas por FMAs não podem ser distinguidas das não-colonizadas pela simples observação macroscópica, já que alterações morfológicas visíveis nas raízes não podem ser detectadas (Silveira, 1992). Apesar de não ocorrerem alterações morfológicas, a formação das MAs é acompanhada por consideráveis mudanças no metabolismo em ambos os simbiontes (Ginzberg et al., 1998). A penetração do fungo e seu estabelecimento nas raízes do hospedeiro envolvem uma seqüência complexa de eventos, os quais resultam na diferenciação das hifas intercelulares terminais em arbúsculos (Bonfante-Fasolo \& Perotto, 1992). Os arbúsculos são 
envoltos por uma membrana plasmática vegetal diferenciada, e têm papel fundamental na transferência bi-direcional de nutrientes entre os simbiontes (Bonfante-Fasolo \& Perotto, 1991).

As MAs têm papel ecológico relevante pois aumentam a absorção de diversos nutrientes, principalmente aqueles com baixa mobilidade na solução do solo, como P, Zn e Cu (Ezeta \& Santos, 1980; Silveira, 1992). Outras vantagens das MAs são: maior tolerância a metais pesados (Nogueira, 1996; Siqueira et al., 1999), doenças (Bodker et al., 1998) e estresse hídrico. A formação de MAs pode resultar também em aumentos da biomassa vegetal (Khaliq \& Sanders, 1997; Khaliq et al., 1997).

\subsubsection{Desenvolvimento de MAs}

O processo de pré-infecção tem início com a germinação dos esporos no solo. A germinação de esporos de FMAs e o crescimento inicial do tubo germinativo podem ocorrer na ausência de raízes, mas exsudatos radiculares e compostos voláteis como o $\mathrm{CO}_{2}$ podem estimular estes processos (Bécard et al., 1992).

Compostos fenólicos específicos presentes nos exsudados radiculares em concentrações reduzidas podem tanto estimular quanto inibir o crescimento de algumas espécies de FMAs (Douds et al., 1996). Partindo-se do princípio que os flavonóides são ativos em concentrações muito baixas, assume-se que eles não possuem efeito nutricional, e, assim, poderiam atuar como sinais moleculares na rizosfera para controlar o crescimento de FMAs (Harrison, 1999). Embora, compostos derivados de flavonóides possam influenciar os estádios iniciais do ciclo de vida do fungo, experimentos com mutantes de milho deficientes na produção de flavonóides indicaram que eles não são essenciais para o estabelecimento da MA (Bécard et al., 1995).

O desenvolvimento da simbiose é iniciado quando a hifa fúngica, originária de um propágulo, entra em contato com a raiz da planta hospedeira e diferencia-se em apressório. Embora os exsudados radiculares sejam capazes de estimular o crescimento da hifa e sua ramificação, eles não são capazes de estimular a formação do apressório (Giovannetti et al., 1993). Recentemente foi demonstrado que Gigaspora margarita pode formar apressório in vitro sobre a parede de células da epiderme isoladas de raízes de cenoura (planta hospedeira), mas não sobre paredes isoladas de células da epiderme de raízes de beterraba açucareira (planta nãohospedeira) (Nagahashi \& Douds, 1997). O fungo também reconheceu o tipo de célula, não formando apressório sobre a parede de células corticais ou vasculares. Estes experimentos 
sugerem que o sinal para a formação do apressório encontra-se na parede de células da epiderme, hipótese anteriormente apresentada por Tester et al. (1987).

A formação do apressório é seguida pelo desenvolvimento da hifa de penetração. Quando apressórios de diferenciam sobre fragmentos de parede celular de células da epiderme, estes não são capazes de formar hifa de penetração (Nagahashi \& Douds, 1997), pois a presença da célula hospedeira, e não apenas do fragmento da parede, é essencial para o sucesso da penetração do fungo micorrízico. Uma grande quantidade de mutantes vegetais nos quais os FMAs formam apressórios, mas não formam hifa de penetração indicam que essa etapa da associação é controlada pela planta. Mutações bloqueando este estádio de diferenciação dos fungos têm sido descritos em Pisum sativum e Vicia faba (Duc et al., 1989), Medicago sativa (Bradbury et al., 1991) e Phaseolus vulgaris (Shirtliffe \& Vessey, 1996).

A penetração pode ocorrer por diferentes vias. Em algumas espécies vegetais a hifa penetra forçando a sua passagem entre duas células epidérmicas; em outros casos, a hifa penetra pela parede do pêlo radicular ou da célula epidérmica e cresce através do apoplasto (Bonfante-Fasolo, 1984). Os mecanismos exatos envolvidos na penetração são desconhecidos. Contudo, por analogia a interações com vários patógenos biotróficos, tem sido sugerido que a produção localizada e específica de enzimas que degradam a parede celular pode facilitar a entrada da hifa sem induzir respostas de defesa vegetal (Bonfante-Fasolo \& Perotto, 1995). Os FMAs produzem, em quantidades relativamente reduzidas, exo- e endoglucanases, xiloglucanases e enzimas pectolíticas, incluindo poligalacturonase (Garcia-Garrido et al., 1992a; Garcia-Garrido et al., 1992b; Garcia-Garrido, 1996).

O tecido cortical pode ser colonizado tanto inter- quanto intracelularmente. Na região mais interna do córtex, hifas intracelulares diferenciam-se em estruturas ramificadas conhecidas como arbúsculos. Muito embora os arbúsculos se diferenciem dentro da célula, eles localizam-se de fato no apoplasto, já que são envolvidos pela membrana plasmática vegetal (membrana periarbuscular). A parede celular dos arbúsculos é menos espessa e menos organizada do que em hifas intercelulares, o que favorece um contato estreito entre os simbiontes. Nesse estádio, os simbiontes são separados apenas por suas membranas e uma matriz apoplástica derivada da planta (Bonfante-Fasolo \& Perotto, 1990; Bonfante-Fasolo \& Perotto, 1992; Smith \& GianinazziPearson, 1988). O período de vida de um arbúsculo é de 5 a 10 dias, sendo que após este período ele colapsa e se decompõe, deixando a célula funcional e capaz de ser infectada novamente 
(Alexander et al., 1988; Alexander et al., 1989). Algumas espécies de FMAs também formam estruturas chamadas vesículas, as quais teriam como função o armazenamento de lipídios (Smith \& Gianinazzi-Pearson, 1988).

Durante a formação das MAs, as hifas fúngicas extrarradiculares desenvolvem-se extensivamente no solo. Este micélio externo tem papel importante nas MAs já que contribui para o aumento da aquisição de nutrientes minerais do solo, a subseqüente translocação para as plantas, a colonização de outras raízes e, em muitos casos, produção de esporos. Além destas funções para a simbiose, o micélio externo contribui para a agregação das partículas do solo e aumento da estabilidade dos agregados, provavelmente através de glicoproteínas produzidas pela hifa (Wright et al., 1996; Wright \& Upadhyaya, 1996).

A infectividade dos FMAs e a eficiência do estabelecimento da simbiose são afetados por diversos fatores. Dentre os fatores químicos do solo, a concentração de fosfato P é o que mais influi nas MAs, afetando, principalmente, o estabelecimento da simbiose. Em última análise, altos níveis de P na planta inibem o estabelecimento das MAs (Silveira, 1992).

\subsubsection{Expressão diferencial de genes em MAs e as metodologias de estudo}

A formação de uma MA funcional é um processo altamente regulado, o qual é acompanhado por modificações moleculares em ambos os parceiros. Estudos para identificar genes que são regulados diferencialmente em resposta ao desenvolvimento de MAs foram iniciados recentemente. Muitas das investigações se concentraram na análise da expressão de genes conhecidos por terem sua expressão modulada em outras interações entre plantas e microrganismos, como genes de defesa vegetal. Até o momento poucos genes vegetais induzidos especificamente em MAs foram identificados (van Buuren et al., 1999; Martin-Laurent et al., 1997; Murphy et al., 1997; Roussel et al., 1997; van Rhijn et al., 1997) e suas funções na simbiose são ainda desconhecidas.

O conhecimento da biologia molecular e regulação do desenvolvimento desta simbiose é limitado. Normalmente a absorção de P é aumentada nas plantas micorrizadas, e a concentração de P na parte aérea é, aparentemente, o fator que regula a simbiose (Harley \& Smith, 1983; Smith \& Gianinazzi-Pearson, 1988). Para a planta hospedeira, o custo da maior absorção de P por MAs está associado à transferência de carboidratos para o fungo. Acredita-se que a simbiose possua mecanismos "auto-regulatórios", onde o nível de infecção pode ser restringido à medida que a 
disponibilidade de P é aumentada, de maneira que o benefício líquido da simbiose seja mantido. Ao mesmo tempo, em condições onde a disponibilidade de P é extremamente baixa, a interação também é bloqueada, uma vez que a associação com os FMAs não apresentaria qualquer vantagem para as plantas, e a interação poderia representar um dispêndio adicional de fotossintetizados (Bucking \& Heyser, 2003). Transportadores de P expressos em hifas externas de Glomus versiforme, e transportadores de açúcares induzidos em raízes de Medicago truncatula colonizadas por G. versiforme já foram identificados e caracterizados (Harrison \& van Buuren, 1995; Harrison, 1996; Liu et al., 1998). Em raízes de milho colonizadas por Glomus clarum ou Gigaspora margarita foi observada a indução de pirofosfatases e ATPases presentes nas membranas microssomais. A ativação de ATPases durante a simbiose micorrízica está de acordo com a idéia de transporte bidirecional de metabólitos na interface simbiótica. Segundo Ramos et al. (2005), a intensa troca de metabólitos entre os simbiontes ativa as ATPases, gerando um déficit energético na célula que causaria a ativação das pirofosfatases.

Embora os mecanismos envolvidos na regulação da colonização intrarradicular e da eficiência simbiótica pelo P não sejam conhecidos, existem evidências mostrando que essa regulação depende do status nutricional da parte aérea (Koide \& Li, 1990; Bolan, 1991). Lambais \& Mehdy (1995) sugerem um modelo para explicar o mecanismo do controle da simbiose envolvendo o P, fitormônios e o sistema de defesa vegetal. Alterações no balanço hormonal causadas pela infecção fúngica, assim como baixos níveis de $\mathrm{P}$ na planta, poderiam resultar na supressão do sistema de defesa vegetal, possibilitando o estabelecimento da simbiose. De maneira inversa, altos níveis de $\mathrm{P}$ poderiam induzir a expressão de certas proteínas de defesa específicas, inibindo o crescimento fúngico intrarradicular. Tem sido observado que o mecanismo de regulação das MAs pelo $\mathrm{P}$ pode envolver também a expressão diferencial de catalases (Lambais et al., 2003).

Como ocorre em várias interações planta-microrganismo, sinais moleculares poderiam ser reconhecidos na membrana plasmática e transmitidos através de mensageiros secundários até sítios de transcrição gênica, regulando o processo de síntese e/ou a estabilidade de transcritos (mRNAs) interação-específicos, e/ou interação-modulados. Em MAs, essa regulação diferencial de genes vegetais e fúngicos específicos, ainda não identificados, seria responsável pelo controle do desenvolvimento e funcionamento da simbiose (Lambais, 1996). O estudo dos processos de sinalização e transdução de sinais em MAs são bastante complexos, pois as diferentes etapas dos 
processos de infecção, colonização e troca de nutrientes são, provavelmente, reguladas por uma permanente sinalização entre os simbiontes (“cross-talking”).

Devido ao possível efeito de proteínas de defesa vegetal no controle do crescimento intrarradicular de FMAs, estudos sobre a regulação dessas proteínas têm predominado nos últimos anos, com ênfase na via biossintética de fitoalexinas isoflavonóides, proteínas envolvidas no reforço da parede celular vegetal, e proteínas hidrolíticas capazes de degradar a parede celular de fungos (Lambais, 1996). Ruiz-Lozano et al. (1999) observaram a indução de sete genes relacionados à defesa vegetal (pI 206, pI 49, pI 176, PR 10, quitinase básica A1, ácido transcinâmico 4-hidrolase e chalcona isomerase) em raízes de ervilha $\mathrm{Myc}^{-} \mathrm{Nod}^{-}$e de ervilha selvagem , inoculadas com G. mosseae e Rhizobium leguminosarum. O acúmulo de transcritos foi mais elevado em mutantes $\mathrm{Myc}^{-}$do que no tipo selvagem, para cinco dos seis genes estudados, durante os primeiros estádios da interação das raízes com $G$. mosseae e $R$. leguminosarum, e a indução da expressão do gene pI 206 está intimamente relacionada com a diferenciação do apressório. A indução precoce de genes de defesa vegetal, tanto em reposta a FMAs quanto rizóbios, reforça a hipótese da existência de mecanismos regulatórios comuns em ambas as simbioses.

Comparações da expressão gênica em MAs têm sido feitas também com base em respostas de defesa observadas em interações planta-patógeno. A via biossintética de fitoalexinas isoflavonóides envolve uma série de enzimas que podem ser reguladas na transcrição por estímulos bióticos e abióticos (Dixon \& Harrison, 1990). Em interações planta-patógeno incompatíveis, normalmente ocorre um acúmulo localizado de fitoalexinas no sítio de infecção e em suas imediações, com conseqüente morte das células do hospedeiro e do patógeno, caracterizando uma resposta de hipersensibilidade $(\mathrm{RH})$. Sintomas semelhantes à RH não são observados durante o desenvolvimento de MAs, exceto em algumas plantas não-hospedeiras (Allen et al., 1989; Parra-Garcia et al., 1992).

Em MAs, a síntese de fitoalexinas parece ser induzida transitoriamente nos estádios iniciais do desenvolvimento da simbiose (Dixon \& Harrison, 1990). Em raízes de alfafa colonizadas por Glomus intraradices, foi observada uma indução transitória, seguida por supressão, da atividade de fenilalanina amônia liase (FAL) e chalcona isomerase (CHI), e acúmulo de seus respectivos mRNAs (Volpin et al., 1994, 1995). O nível de mRNA de FAL e de chalcona sintase (CHS) foi induzido em raízes de alfafa colonizadas por $G$. versiforme nos estádios iniciais de 
desenvolvimento de MA, enquanto que o acúmulo de mRNA de isoflavona redutase foi suprimido, quando comparado com raízes não-micorrizadas (Harrison \& Dixon, 1993).

Quitinases vegetais, enzimas líticas que catalisam a hidrólise de quitina, são conhecidas por apresentarem atividade constitutiva em muitos tecidos vegetais, mas sua expressão também é induzida durante a infecção de plantas por microrganismos patogênicos (Boller, 1987; Collinge et al., 1993) ou estimulada por elicitação abiótica (Boller, 1988). As quitinases são consideradas como componentes importantes do sistema de defesa vegetal. Em experimentos in vitro, quitinases podem hidrolisar parcialmente a parede celular fúngica (Boller et al., 1983) e inibir o crescimento de certos fungos fitopatogênicos (Schlumbaum et al., 1986).

Normalmente, quitinases apresentam indução transitória em raízes micorrizadas, seguida de supressão (Spanu, et al., 1989; Lambais \& Mehdy, 1993; Volpin et al., 1994). Isoformas ácidas de quitinases podem apresentar indução localizada em células contendo arbúsculos e/ou em sua vizinhança, em condições de alto P (Lambais \& Mehdy, 1998). A regulação diferencial de quitinases pode ser afetada tanto pelo genótipo da planta quanto do fungo. Em feijão, a atividade específica de quitinases é suprimida em raízes colonizadas por um isolado mais infectivo, quando comparado com um isolado menos infectivo (Lambais \& Mehdy, 1996). FMAs contêm quitina em suas paredes celulares (Smith \& Gianinazzi-Pearson, 1988) e podem, portanto, ser hidrolisadas pelas quitinases produzidas nas raízes das plantas hospedeiras, especialmente nos estádios iniciais do processo de infecção. Todavia, algumas quitinases de plantas parecem não entrar em contato direto com as hifas externas de FMAs (Spanu et al., 1989). A expressão constitutiva de quitinases básicas em plantas transgênicas de Nicotiana sylvestris também não afeta a colonização das raízes por G. mosseae (Vierheilig et al., 1993).

Receptores transmembrânicos com um domínio de quinase de proteínas, conhecidos como RPKs (“receptor protein kinases”), têm papel importante na percepção e transdução de sinais em animais (Fantil et al., 1993) e possivelmente em plantas (Walker, 1994; Braun \& Walker, 1996). Foi identificada uma nova classe de RLK (“receptor-like protein kinase”), denominada PvRK 2014, a qual é expressa em raízes, provavelmente em resposta a injúrias. A expressão desse gene foi suprimida em raízes colonizadas por G. mosseae e Rhizobium tropici (Lange et al. 1999).

Várias abordagens metodológicas têm sido utilizadas para identificar genes com expressão diferencial em MAs, dentre elas o “display” diferencial de cDNAs (DDRT-PCR) (Ditt \& 
Lambais, 1997; David et al., 1998; Lange et al., 1999; Harrier et al., 1998) e a seleção diferencial (“differential screening”), combinado com hibridação subtrativa (van Buuren et al., 1999).

Os estudos utilizando estas abordagens metodológicas para o entendimento de simbioses foram feitos inicialmente com interações rizóbio-leguminosas, e posteriormente com MAs. Em 1997, foi construída uma biblioteca utilizando mRNA de Lotus japonicum com o objetivo de investigar os fenômenos envolvidos na organogênese do nódulo. Foram obtidos 110 clones com expressão diferencial em nódulos. Esses clones apresentaram alta similaridade com fosfatase 2C específica do nódulo, transportadores de peptídios e uma forma de citocromo P450 específica do nódulo, entre outros genes. Análises de Northern blots utilizando 16 ESTs diferencialmente expressas confirmaram o seu perfil de expressão específico no nódulo (Szczyglowski et al., 1997).

Pode-se prever que estudos caracterizando perfis de expressão de muitos genes, tais como seqüenciamento de ESTs ou hibridização de cDNAs em macro e microarranjos poderão revelar um grande número de genes essenciais para o desenvolvimento de simbioses (MAs ou rizóbioleguminosas), e que ainda não foram identificados por análise de mutantes ou hibridização diferencial (Manthey et al., 2004).

Nos últimos anos, diversos projetos de seqüenciamento de plantas modelo foram conduzidos. Os avanços dos projetos genoma de leguminosas como Medicago truncatula e Lotus japonicum (Handberg \& Stougaard, 1992) têm permitido a identificação de vários genes com expressão diferencial em simbioses. De uma biblioteca de ESTs específica de nódulos de $M$. truncatula, 389 clones foram seqüenciados, sendo que 34,2\% das seqüências não apresentaram similaridade significativa a seqüências já depositadas em bancos de dados. Entre os clones que apresentaram similaridade significativa com seqüências já depositadas foram encontradas 26 nodulinas. Os clones obtidos foram utilizados para a análise de expressão por hibridização em “Northern blots”, e 33 clones representando genes codificando nodulinas já conhecidas apresentaram acúmulo induzido de transcritos nos nódulos. Com esta abordagem foi possível identificar genes relacionados à nodulação e genes específicos do nódulo (Gyorgyey et al., 2000).

Dados obtidos nos projetos de seqüenciamento de ESTs foram utilizados em análises in silico ("Northerns blots" eletrônicos) para a identificação de genes com perfil de expressão diferencial. Fedorova et al. (2002) utilizaram o "TIGR Medicago truncatula Gene Index (MtGI)” para encontrar genes específicos do nódulo e Journet et al. (2002) fizeram a análise in silico da 
base de dados "Medicago EST Navigation System (MENS)” para identificar genes com expressão diferencial putativa em nódulos, micorrizas arbusculares ou ambas as simbioses.

Apesar das diferenças óbvias entre as associações micorrízicas e a associação rizóbioleguminosa, em ambas as associações vários dos genes ativados são comuns, sugerindo que estas associações simbióticas compartilham algumas vias de transdução de sinais (Manthey et al., 2004).

Além de "Northerns blots” eletrônicos, as bases de dados de ESTs podem ser usadas para gerar arranjos de DNA para análises da expressão gênica em larga escala. Transcritomas de $L$. japonicum (Colebatch et al., 2002; Endo, 2002), Glycine max (Maguire et al., 2002), M. truncatula (Liu et al., 2003) e Lupinus albus (Uhde-Stone et al., 2003) já foram analisados com base em hibridização com arranjos de DNA. Os mais relevantes para o estudo das simbioses foram os experimentos de Colebatch et al (2002) e Liu et al. (2003), nos quais mais de 50 genes induzidos pela nodulação e mais de 60 genes induzidos por MAs, respectivamente, foram identificados.

A construção de bibliotecas de ESTs também já foi utilizada em estudos de ectomicorrizas formadas entre Eucaliptus globulus e Pisolithus tinctorius (Voiblet et al., 2001). Foram seqüenciados e analisados 850 clones de cDNA e selecionados 486 para a hibridização com cDNA proveniente da micorriza, de raízes não-colonizadas e das hifas do fungo. Cerca de $17 \%$ dos clones selecionados apresentaram alteração no acúmulo de seus mRNAs devido a colonização micorrízica.

A análise de genes modulados apenas na interação micorrízica arbuscular foi feita através da técnica de hibridização subtrativa, a partir de raízes de M. truncatula colonizadas por Glomus intraradices. Este estudo resultou na identificação de vários genes regulados especificamente pela colonização micorrízica, dentre eles, genes codificando transportadores de fosfato, precursores de lectina, transportadores de nitrato e uma glutationa S-transferase induzida por 2,4D. Nas análises de RT-PCR (Real Time - PCR; PCR em tempo real), todos estes genes apresentaram indução em raízes micorrizadas, quando comparados com raízes não micorrizadas ou folhas, comprovando que são genes específicos da associação micorrízica (Wulf et al., 2003).

\subsubsection{Micorrizas arbusculares e cana-de-açúcar}


Atualmente, são poucos os estudos desenvolvidos sobre micorrizas arbusculares e cana-deaçúcar. Este baixo interesse sobre a micorrização em cana-de-açúcar ocorre principalmente em virtude da baixa dependência micotrófica desta espécie vegetal (Siqueira \& Franco, 1988). Por ser uma gramínea de ciclo longo, os efeitos da inoculação com FMAs não podem ser avaliados em experimentos de curta duração em casa-de-vegetação, onde os fatores climáticos são controlados.

Em condições de casa-de-vegetação, foi conduzido um experimento para observar a associação de raízes de cana-de-açúcar com comunidades de FMAs provenientes de dois tipos diferentes de solos. A comunidade de FMAs presente no solo proveniente de mata apresentou maior número de esporos e maior colonização radicular do que a comunidade presente em solos obtidos de canaviais comerciais.Além disso o maior número de esporos e maior taxa de colonização resultou em aumentos significativos em diversos parâmetros biométricos: peso da matéria fresca, altura e número de entrenós (Takahashi, et al., 1998).

Alguns estudos de campo foram conduzidos para avaliar a diversidade e a ocorrência de FMAs em diversas culturas, inclusive cana-de-açúcar. Siqueira et al. (1989) estudaram vários agrossistemas em Minas Gerais e observaram que o solo sob cultivo de cana-de-açúcar foi o que apresentou maior diversidade de espécies fúngicas. Andreola (1982) realizou um levantamento de FMAs em canaviais plantados em Araras (SP) e identificou sete espécies de FMAs. O autor observou que a ocorrência de esporos no solo dos gêneros Acaulospora e Gigaspora foi de 4\% a 30\%, e do gênero Glomus variou de 70\% a 96\%. O nível de fertilidade do solo não influenciou o número de esporos no solo nem a porcentagem de colonização das raízes. Resultados semelhantes foram encontrados anteriormente por Dainese \& Cardoso (1981), em que também houve predomínio do gênero Glomus em mais de 70\% das amostras.

Outro estudo de diversidade de FMAs, realizado por Reis et al. (1999) em canaviais localizados nos Estados do Rio de Janeiro e Pernambuco, mostrou que a adoção da queima do palhiço nos canaviais por ocasião da colheita diminui o número de esporos no solo e a diversidade dos FMAs. As espécies predominantes nos canaviais amostrados foram: Acaulospora sp., Scutelospora heterogama, Glomus etunicatum, Glomus occultum e Gigaspora margarita.

Experimentos conduzidos nas Filipinas, mostraram a associação natural que ocorre entre Saccharum spontaneum e FMAs (Oba at al., 2004). Em regiões de deposição de cinzas provenientes da erupção vulcânica do Monte Pinatubo, S. spontaneum é uma das poucas espécies 
pioneiras na recolonização destas áreas. A colonização das raízes de $S$. spontaneum por FMAs foi baixa e na rizosfera foram encontrados 8 morfotipos de esporos de FMAs, sugerindo que apesar da baixa taxa de colonização, $S$. spontaneum é importante para a manutenção da diversidade de espécies de FMAs.

\subsection{Material e métodos}

\subsubsection{Instalação do experimento}

Plântulas micropropagadas de cana-de-açúcar (Saccharum spp.) da variedade SP80-3280 (a mesma utilizada no projeto SUCEST) provenientes do CTC (Centro de Tecnologia Canavieira Piracicaba - SP) foram plantadas em bandeja de isopor contendo substrato esterilizado composto por areia lavada + vermiculita $(2: 1, \mathrm{v} / \mathrm{v})$. A bandeja foi coberta com plástico transparente para a aclimatação das plântulas por um período de duas semanas.

Após o período de aclimatação, as plântulas foram transplantadas para vasos contendo $1 \mathrm{~kg}$ do mesmo substrato e adubadas com: 240 mg de N (dividido em três aplicações a cada 20 dias), 300 mg de K, 120 mg de Ca, 60 mg de Mg, 1 mL de solução de Fe-EDTA de Hoagland e 1 mL de solução de micronutrientes de Hoagland por vaso (Sarruge, 1975). A adubação fosfatada foi feita com 20 ou $200 \mathrm{mg} \mathrm{P} \mathrm{kg}^{-1}$ substrato, representando baixo e alto teor de $\mathrm{P}$, respectivamente.

A inoculação com o fungo micorrízico Glomus clarum (Nicol. \& Schenck) foi realizada no momento do transplantio. O inóculo (aproximadamente $30 \mathrm{~mL}$ ) constou de uma mistura de solo, esporos fúngicos e fragmentos de hifas e raízes de Brachiaria colonizadas, obtidas de vasos de multiplicação. As plantas controles receberam mistura de solo e raízes de Brachiaria nãocolonizadas.

A colheita do experimento foi feita em duas épocas: quatro e oito semanas após o transplantio. As plantas foram retiradas dos vasos e tiveram a parte aérea e as raízes separadas. A parte aérea foi colocada em estufa a $70^{\circ} \mathrm{C}$ até atingir massa constante, para a determinação da massa da matéria seca da parte aérea. As raízes foram lavadas com água destilada em abundância para a retirada do substrato aderido. Foram coletadas amostras do terço médio do sistema radicular e armazenadas em etanol 70\%, o restante do sistema radicular foi congelado em nitrogênio líquido e armazenado a $-80^{\circ} \mathrm{C}$.

O delineamento experimental utilizado foi inteiramente casualizado, em esquema fatorial 2x2x2 com 10 repetições, sendo dois os níveis de adubação fosfatada (20 e $200 \mathrm{mg} \mathrm{kg}^{-1}$ ), dois 
tratamentos de inoculação (inoculado com G. clarum e não-inoculados) e duas épocas de colheita (oito e doze semanas após o transplantio), perfazendo um total de 80 unidades experimentais.

O experimento foi conduzido em condições de casa-de-vegetação no Departamento de Solos e Nutrição de Plantas da ESALQ/USP.

\subsubsection{Análises laboratoriais}

\subsubsection{Avaliação da colonização micorrízica}

As amostras de raízes armazenadas em etanol 70\% foram lavadas com água destilada e descoradas com a adição de $\mathrm{KOH} 10 \%$ por $60 \mathrm{~min}$ a $90^{\circ} \mathrm{C}$. Em seguida, as raízes foram imersas em solução corante (ácido acético 5\%, tinta de caneta Parker 5\%) por 3 min a $90^{\circ} \mathrm{C}$, lavadas em ácido acético 5\% para parar a reação e retirar o excesso de tinta e armazenadas em lactoglicerol (Vierheilig et al., 1998). A avaliação da colonização intrarradicular foi feita em microscópio estereoscópico, determinando-se a presença de estruturas fúngicas (hifas, arbúsculos e vesículas) no tecido cortical, em placas reticuladas, segundo o método descrito por Giovanetti \& Mosse (1980).

\subsubsection{Extração de RNA}

As raízes foram maceradas em almofariz contendo nitrogênio líquido, e o RNA total foi extraído, utilizando-se 10 volumes de uma solução monofásica (38\% de fenol, 0,8 M de tiocianato de guanidina, 0,4 M de Tiocianato de amônio, 0,1 M de acetato de sódio pH 5,5 e 5\% de Glicerol), conforme o protocolo desenvolvido por K. Sathasivan (2002, não publicado). As raízes foram homogeneizadas com agitação vigorosa por 1 min e incubadas a $30^{\circ} \mathrm{C}$ por $10 \mathrm{~min}$. Em seguida, as amostras foram centrifugadas a $12000 \mathrm{~g}$ por $10 \mathrm{~min}$ a $4^{\circ} \mathrm{C}$. O sobrenadante foi transferido para tubo limpo onde foi adicionado $1 / 5$ de volume de clorofórmio, as amostras foram, então, agitadas vigorosamente por 30 segundos e incubadas a temperatura ambiente por 4 $\min$. As amostras foram novamente centrifugadas a $12000 \mathrm{~g}$ por $10 \mathrm{~min}$ a $4^{\circ} \mathrm{C}$. A fase aquosa foi transferida para tubo novo e foi adicionado 1/3 de volume de SSC (0,8 M de citrato de sódio e 1,5M de Cloreto de Sódio) e 2/3 de volume de álcool isopropílico. As amostras foram incubadas por $12 \mathrm{~h} \mathrm{a}-20^{\circ} \mathrm{C}$ e centrifugadas a $14000 \mathrm{~g}$ por $15 \mathrm{~min}$ a $4^{\circ} \mathrm{C}$. O sobrenadante foi descartado e o pélete lavado com etanol $75 \%$. O RNA peletizado foi seco por $10 \mathrm{~min}$ a $37^{\circ} \mathrm{C}$ e solubilizado em $\mathrm{H}_{2} \mathrm{O}$ tratada com DEPC (dietilpirocarbonato). 
As amostras de RNA total foram tratadas com 10 U de DNase I livre de RNase (Boehringer Mannhein) em $20 \mathrm{mM}$ Tris- $\mathrm{HCl}$ (pH 8,4), $50 \mathrm{mM} \mathrm{KCl}$ e $20 \mathrm{mM} \mathrm{MgCl}_{2}$ e incubadas por $2 \mathrm{~h}$ a $37^{\circ} \mathrm{C}$. O RNA foi então extraído uma vez com fenol saturado em água, uma vez com fenol:clorofórmio:álcool isoamílico (25:24:1, vol:vol:vol). O sobrenadante foi precipitado com $300 \mathrm{mM}$ acetato de sódio ( $\mathrm{pH}$ 5,5) e 2,5 volumes de etanol. O pélete foi lavado com etanol 75\%, seco por 10 min a $37^{\circ} \mathrm{C}$ e dissolvido em $\mathrm{H}_{2} \mathrm{O}$ tratada com DEPC.

A concentração de RNA total foi determinada por espectrofotometria a 260nm $\left(1\right.$ OD $_{260}=$

$40 \mu \mathrm{g}$ de RNA mL ${ }^{-1}$ ). A qualidade do RNA foi determinada através das razões $A_{260} / A_{280}$ e $A_{260} / A_{230}$. A integridade do RNA foi verificada através de eletroforese em gel de agaroseformaldeído 1,2\%, utilizando-se brometo de etídeo $\left(0,5 \mu \mathrm{g} \mathrm{mL}^{-1}\right)$ para visualização das bandas (Sambrook et al. 1989). A aquisição da imagem dos géis foi feita utilizando-se um densitômetro a laser “FluorImager SI” (Amersham Biosciences).

\subsubsection{Biblioteca subtrativa supressiva}

\subsubsection{Síntese da primeira fita de cDNA}

A síntese da primeira fita de cDNA foi feita com o kit "SUPERSCRIPT ${ }^{\mathrm{TM}}$ Preamplification system for first strand cDNA synthesis” (Invitrogen), conforme instruções do fabricante. Partiuse de $2 \mu \mathrm{g}$ de RNA total de cada tratamento, 50 ng de iniciadores Oligo-dT $\mathrm{T}_{(12-18)}$ e água tratada com DEPC para volume final de $12 \mu \mathrm{L}$. A solução foi aquecida a $70^{\circ} \mathrm{C}$ por 10 min e resfriada em gelo por 1 min. Foi adicionado tampão PCR 1x (20 mM de Tris-HCl pH 8,4 e 50 mM de KCl), 2,5 $\mathrm{mM} \mathrm{MgCl}_{2}, 500 \mu \mathrm{M}$ dNTPs e $10 \mathrm{mM}$ DTT. As amostras foram incubadas por 5 min a $42^{\circ} \mathrm{C}$ e, em seguida foi adicionado 200U de transcritase reversa Superscript II. Incubou-se por 50 min a $42^{\circ} \mathrm{C}$ e em seguida as enzimas foram inativadas a $70^{\circ} \mathrm{C}$ por 15 min. Foram adicionadas $2 \mathrm{U}$ de RNaseH às reações, e incubou-se por 20 min a $37^{\circ} \mathrm{C}$, para a degradação das fitas de RNA dos híbridos de cDNA:RNA formados. As soluções de cDNA foram armazenadas a $-80^{\circ} \mathrm{C}$.

\subsubsection{Síntese da segunda fita de cDNA e amplificação}

O cDNA obtido foi utilizado nas amplicações por PCR realizadas nas seguintes condições: solução tampão PCR 1X (20 mM de Tris-HCl pH 8,4 e 50 mM de $\mathrm{KCl}$ ), 4 mM $\mathrm{MgCl}_{2}, 3$ mM dNTPs $0,1 \mu \mathrm{M}$ de iniciadores aleatórios e $1 \mathrm{U}$ de Taq-DNA polimerase. A amplificação foi 
realizada em um ciclo a $94^{\circ} \mathrm{C}$ por $3 \mathrm{~min}, 35$ ciclos de 1 min a $94^{\circ} \mathrm{C}, 1 \min$ a $50^{\circ} \mathrm{C}$ e $1 \min$ a $72^{\circ} \mathrm{C}$ e uma extensão final por $10 \mathrm{~min}$ a $72^{\circ} \mathrm{C}$.

Os produtos da reação acima foram separados através de eletroforese em gel de agarose 1,2\% - TBE 0,5X. O DNA foi visualizado por coloração com SYBR-Green I (Molecular Probes) após varredura em densitômetro a laser “FluorImager SI” (Amersham Bioscience).

\subsubsection{PCR subtrativo supressivo}

A biblioteca subtrativa foi construída utilizando o kit "PCR select cDNA subtractive synthesis kit” (Clontech). Os cDNAs de fita dupla obtidos no item anterior foram digeridos com a enzima de restrição RsaI. O cDNA “tester” (tratamento baixo P inoculado com Glomus clarum) foi dividido em duas porções e cada uma delas foi ligada a diferentes adaptadores (1 e 2R). Os dois adaptadores possuem complementaridade com seqüências idênticas que permitem o pareamento com o iniciador da PCR.

Foram feitas duas hibridizações. Na primeira hibridização, foi adicionado um excesso de cDNA “driver” (tratamento baixo P, não-inoculado) a cada amostra de cDNA tester. As amostras foram desnaturadas por aquecimento e posteriormente renaturadas. Na segunda hibridização, as duas amostras hibridizadas foram misturadas sem desnaturação. Neste momento, apenas cDNAs de fita simples do "tester” poderiam reassociar-se e formar um novo tipo de híbrido. Estes novos híbridos são moléculas "tester" dupla fita com diferentes extremidades, que correspondem às seqüências dos adaptadores 1 e 2R. O cDNA “driver” desnaturado foi hibridizado com os transcritos da amostra "tester”, enriquecendo a fração de seqüências diferencialmente expressas.

A mistura entre cDNAs “tester" e "driver" foram amplificadas por PCR utilizando iniciadores específicos que pareiam com os adaptadores 1 e 2R presentes apenas na amostra “tester”. Posteriormente, foi feita nova amplificação por PCR usando iniciadores internos para reduzir quaisquer produtos de PCR não-específicos e enriquecer em seqüências expressas diferencialmente. Os produtos da amplificação foram separados através de eletroforese em gel de agarose 1,2\% - TBE 0,5X. O DNA foi visualizado por coloração com SYBR-Green I (Molecular Probes) após varredura em densitômetro a laser “FluorImager SI” (Amersham Bioscience).

\subsubsection{Clonagem dos fragmentos}


Os fragmentos obtidos na etapa anterior foram clonados no vetor pGEM-T Easy Vector (Promega), de acordo com as instruções do fabricante. A reação de ligação dos produtos de PCR ao plasmídeo pGEM-T-Easy foi feita utilizando-se tampão de ligação rápida 1X (30 mM Tris$\mathrm{HCl} \mathrm{pH} \mathrm{7,8,} 10 \mathrm{mM} \mathrm{MgCl}_{2}, 10 \mathrm{mM}$ DTT, $1 \mathrm{mM}$ ATP, 5\% polietileno glicol) e $3 \mathrm{U}$ de DNA ligase T4. Esse material foi incubado a $4^{\circ} \mathrm{C}$ durante $12 \mathrm{~h}$. Em seguida, células competentes de $E$. coli $\mathrm{DH} 5 \alpha$ foram transformadas por choque térmico utilizando a reação de ligação obtida. Após plaqueamento em meio LB-ágar contendo ampicilina $\left(50 \mu \mathrm{g} \mathrm{mL}^{-1}\right)$ e X-Gal (5-bromo-4-cloro-3indolil- $\beta$-D-galactosideo; $20 \mu \mathrm{g} \mathrm{mL} \mathrm{m}^{-1}$ ) foram selecionadas colônias brancas, contendo o plasmídeo recombinante. As bactérias contendo plasmídeos de interesse foram cultivadas em meio LB líquido com ampicilina (50 $\mu \mathrm{g} \mathrm{mL}^{-1}$ de meio).

Os plasmídeos foram extraídos de acordo com o método descrito no item 2.2.7 e o DNA foi seqüenciado conforme descrito no item 2.2.8.

\subsubsection{Biblioteca de cDNA}

\subsubsection{Isolamento de mRNA}

O mRNA foi isolado utilizando o kit Oligotex (Quiagen), de acordo com a recomendação do fabricante. O RNA total armazenado em 1/10 volume de 3 M acetato de sódio (pH 5,5) e 2,5 volumes de etanol 100\% foi precipitado e recuperado por centrifugação a $14000 \mathrm{~g}$ por $30 \mathrm{~min}$ a $4^{\circ} \mathrm{C}$. O pélete obtido foi lavado com etanol $70 \%$ e seco por $10 \mathrm{~min}$ a $37^{\circ} \mathrm{C}$. O pélete foi dissolvido em $250 \mu \mathrm{L}$ de água-DEPC. Foi utilizada uma alíquota de $1 \mu \mathrm{L}$ de RNA total para a quantificação em espectrofotômetro a $260 \mathrm{~nm}$. De acordo com a quantidade de RNA total obtida, foi adicionado água-DEPC, tampão OBB e suspensão da resina Oligotex. Esta solução foi incubada por $3 \mathrm{~min}$ a $70^{\circ} \mathrm{C}$ para quebrar as estruturas secundárias do RNA e incubada novamente por 10 min a temperatura ambiente $\left(20\right.$ a $\left.30^{\circ} \mathrm{C}\right)$. O complexo formado pelo mRNA ligado à resina Oligotex foi peletizado por centrifugação a $14000 \times \mathrm{g}$ por 2 min e o sobrenadante foi descartado. O complexo Oligotex:mRNA foi suspendido em tampão OW2 e purificado em filtros (Millipore). O eluato recolhido foi descartado, e o procedimento de lavagem repetido novamente. Para a eluição do mRNA, foi adicionado $100 \mu \mathrm{L}$ de tampão OEB aquecido a $70^{\circ} \mathrm{C}$. Ao eluato obtido foi adicionado 1/20 volume de glicogênio (50 $\mu \mathrm{g} \mathrm{mL}^{-1}$ ), 1/10 volume de 7,5 M acetato de amônio e 2,5 volume de etanol 100\%. O mRNA poliA(+) foi precipitado a $-80^{\circ} \mathrm{C}$ durante $12 \mathrm{~h}$. 
A concentração de mRNA poliA(+) foi determinada por espectrofotometria a $260 \mathrm{~nm}(1$ $\mathrm{OD}_{260}=40 \mu \mathrm{g}$ de RNA mL $\left.{ }^{-1}\right)$. A qualidade do mRNA poliA(+) foi determinada através das razões $A_{260} / A_{280}$ e $A_{260} / A_{230}$. A integridade do mRNA poliA(+) foi verificada através de eletroforese em gel de agarose-formaldeído 1,2\%, utilizando-se brometo de etídeo $\left(0,5 \mu \mathrm{g} \mathrm{mL}^{-1}\right)$ para visualização das bandas (Sambrook et al. 1989). A aquisição da imagem dos géis foi feita utilizando-se um densitômetro a laser "FluorImager SI” (Amersham Biosciences).

\subsubsection{Construção das Bibliotecas de cDNA}

As bibliotecas de cDNA foram construídas utilizando o kit "SuperScript cDNA Synthesis and Plasmid Cloning” (Invitrogen), de acordo com as instruções do fabricante. Quatro microgramas de mRNA poli(A)+ foram utilizados para a transcrição reversa com um iniciador poli-dT contendo o sítio de restrição NotI. A eficiência da síntese de cDNA foi monitorada com o uso de dCTP marcado com ${ }^{32} \mathrm{P}$. A segunda fita de cDNA foi então sintetizada pela troca do RNA nos híbridos pelo DNA utilizando uma combinação de RNase H, DNA Polymerase I e DNA LigaseT4. Após a síntese da segunda fita e a ligação de adaptadores SalI, o cDNA foi digerido com NotI , gerando cDNAs flanqueados por sítios SalI nas extremidades 5' e sítios NotI nas extremidades 3'. O excesso de adaptadores foi removido, e os cDNAs foram fracionados por cromatografia em coluna de Sepharose, utilizando TEN (10 mM Tris- $\mathrm{HCl}, \mathrm{pH}$ 7,5, 0,1 mM EDTA e $25 \mathrm{mM} \mathrm{NaCl}$ ) como tampão de eluição. Vinte e cinco frações de aproximadamente 30 $\mu \mathrm{L}$ foram coletadas e alíquotas destas frações foram separadas por eletroforese em gel de agarose 1,5\%. O gel foi autoradiografado para determinar o tamanho e qualidade de cDNAs nas diferentes frações. Frações com cDNAs acima de 500 pb foram misturadas e os cDNAs ligados ao vetor pSPORT1 (Invitrogen), previamente digerido com SalI e NotI. Os plasmídeos recombinantes foram transformados em células competentes de E. coli DH10B por eletroporação, utilizando um campo elétrico de $\sim 16,6 \mathrm{kV} / \mathrm{cm}$ e pulso com duração de $\sim 4 \mathrm{~ms}$. As células transformadas foram plaqueadas em meio ágar-LB contendo $100 \mathrm{mg} \mathrm{L}^{-1}$ de ampicilina. As colônias individuais foram transferidas para placas com 96 poços contendo meio líquido Circle Grow (CG) (BIO101), suplementado com $100 \mathrm{mg} \mathrm{L}^{-1}$ de ampicilina e 8\% de glicerol. As placas contendo os clones foram armazenadas a $-80^{\circ} \mathrm{C}$.

Os plasmídeos foram extraídos de acordo com o método descrito no item 2.2.7 e o DNA foi seqüenciado conforme descrito no item 2.2.8. 


\subsubsection{Extração dos plasmídeos}

Após o cultivo das bactérias em meio LB líquido a $38^{\circ} \mathrm{C}$ sob agitação por $22 \mathrm{~h}$, o meio foi centrifugado a $4000 \mathrm{~g}$ por $5 \mathrm{~min}$ a $4^{\circ} \mathrm{C}$. O pélete foi lavado com solução contendo $25 \mathrm{mM}$ Tris$\mathrm{HCl}$ pH 8,0, 10 mM EDTA pH 8,0 e 50 mM glicose. Em seguida, foi adicionada a solução contendo $1 \%$ SDS, 0,2N NaOH e incubada no gelo por 10 min. Foi adicionada a solução contendo $3 \mathrm{M}$ acetato de potássio e 10\% ácido acético glacial, misturada por inversão, incubada em gelo por $10 \mathrm{~min}$ e centrifugada a $4000 \mathrm{~g}$ por $20 \mathrm{~min}$ a $4^{\circ} \mathrm{C}$. O sobrenadante foi transferido para nova placa, sendo adicionado $15 \mu \mathrm{g}$ de RNaseA, e incubou-se a $37^{\circ} \mathrm{C}$ por $20 \mathrm{~min}$. O DNA foi precipitado com isopropanol gelado e incubado em gelo por $5 \mathrm{~min}$. O precipitado foi centrifugado a $4000 \mathrm{~g}$ por $40 \mathrm{~min}$ a $4^{\circ} \mathrm{C}$ e o pélete foi lavado com etanol $70 \%$ gelado. O pélete foi então seco e dissolvido em água deionizada esterilizada. A concentração de DNA foi determinada através de espectrofotometria a $260 \mathrm{~nm}$ e sua integridade foi analisada por eletroforese em gel de agarose 1,2\% -TBE 0,5X. O DNA foi visualizado por coloração com SYBR-Green I (Molecular Probes) após varredura em densitômetro a laser “FluorImager SI” (Amersham Bioscience).

\subsubsection{Seqüenciamento}

\subsubsection{Seqüenciamento utilizando "Big Dye Terminator"}

Para o seqüenciamento foi utilizada uma alíquota de 200 - 500 ng de DNA plasmidial. Ao DNA plasmidial foi adicionado 10 pmol do iniciador M13F ou M13R, 2,0 $\mu \mathrm{L}$ de "Big Dye Terminator Cycle Sequencing Ready Reaction” (Perkin Elmer Applied Biossystems), 2,0 $\mu \mathrm{L}$ de tampão de seqüenciamento 5X e água deionizada para um volume final de $10 \mu \mathrm{L}$. A amplificação foi realizada nas seguintes condições: um ciclo a $94^{\circ} \mathrm{C}$ por $3 \mathrm{~min}$, 35 ciclos de $1 \mathrm{~min}$ a $94^{\circ} \mathrm{C}, 1$ min a $50^{\circ} \mathrm{C}$ e 1 min a $72^{\circ} \mathrm{C}$ e uma extensão final por 10 min a $72^{\circ} \mathrm{C}$. Os produtos de PCR foram precipitados com isopropanol 75\% e incubados no escuro por $20 \mathrm{~min}$ a temperatura ambiente. Foram centrifugados a $4000 \mathrm{~g}$ por $45 \mathrm{~min}$ a $4^{\circ} \mathrm{C}$ e os péletes foram lavados em etanol $70 \%$. Os péletes foram secos no escuro, dissolvidos em formamida e desnaturados a $96^{\circ} \mathrm{C}$ por $5 \mathrm{~min}$.

\subsubsection{Seqüenciamento utilizando "DYEnamic ET Terminator"}

Para o seqüenciamento foi utilizada uma alíquota de 200-500 ng de DNA plasmidial. Ao DNA plasmidial foi adicionado 10 pmol do iniciador T7, $2 \mu \mathrm{L}$ de "DYEmanic ET Terminator" (Amersham Biosciences), $2 \mu \mathrm{L}$ de tampão Save Money (200 mM Tris-HCl pH 9,0 e 5 mM 
$\mathrm{MgCl}_{2} \cdot 6 \mathrm{H}_{2} \mathrm{O}$ ) e água deionizada para um volume final de $10 \mu \mathrm{L}$. A amplificação foi realizada nas seguintes condições: 25 ciclos de 20 segundos a $95^{\circ} \mathrm{C}, 15$ segundos a $50^{\circ} \mathrm{C}$ e 1 min a $60^{\circ} \mathrm{C}$. Os produtos de PCR foram precipitados com 1/10 de volume de uma solução de acetato de sódio 1,5 M e EDTA $250 \mathrm{mM}$ e 6 volumes de etanol 95\%. Foram centrifugados $4000 \mathrm{~g}$ por $45 \mathrm{~min}$ e os péletes foram lavados em etanol 70\%. Os péletes foram secos no escuro por no mínimo 2 horas e ressolubilizados em formamida.

\subsubsection{Análises de bioinformática}

Os cromatogramas gerados no seqüenciamento dos clones de cDNA foram inicialmente analisados pelo programa Phred/Phrap (Ewing et al., 1998), para remoção de vetor contaminante e bases de baixa qualidade. Foram aceitas apenas as sequências que apresentaram pelo menos 300 bases com qualidade $>20$. Este valor de qualidade representa 1 erro em cada 100 bases lidas. As sequências com qualidade acima do mínimo estipulado foram agrupadas utilizando-se o programa Cap3 (Huang \& Madan, 1999). Para formar os clusters, as sequências deveriam apresentar no mínimo 30 bases de similaridade e $90 \%$ de identidade (-o 30 e -p 90). As sequências consenso dos “clusters" e as sequências "singletons” (seqüências que não formaram cluster foram comparadas com seqüências depositadas nos bancos de dados do NCBI e SUCEST.

Adicionalmente foi calculado o Índice de Sucesso (eq. 1) e o Índice de Novidade (eq. 2) de cada biblioteca e do projeto.

$$
\begin{gathered}
\text { IS }=\frac{\text { total de sequências com qualidade }}{\text { total sequenciado }} \cdot 100 \\
\text { IN }=\frac{\text { número de clusters }+ \text { número de singletons }}{\text { total de sequências com qualidade }} \cdot 100
\end{gathered}
$$

\subsubsection{Análise de expressão in silico}

Os perfis de expressão dos “clusters” foram analisados por agrupamento hierárquico (Eisen et al., 1998). Para cada “cluster” foi determinada a freqüência de reads e este número foi normalizado para o número total de reads válidos em cada biblioteca. O agrupamento hierárquico dos “clusters" e das bibliotecas foi feito utilizando-se uma matriz de correlação descentralizada e o método de ligação de médias (“average-linkage method”), através dos programas Cluster and Tree View (Eisen et al., 1998). A matriz de dados foi reordenada de acordo com as similaridades 
entre os perfis de expressão dos genes, e mostradas como arranjos coloridos que utilizam uma escala de cores representando o número relativo de reads de uma biblioteca específica para cada "cluster".

\subsubsection{Análise de expressão em macroarranjos de DNA}

\subsubsection{Preparação das membranas de alta densidade}

Foram selecionadas 384 ESTs dentre as seqüenciadas nas 4 bibliotecas de cDNA e uma biblioteca subtrativa com expressão diferencial putativa, com base em análises de Northern eletrônicos. Estes clones foram arranjados em microplacas (96 poços) em duplicatas, totalizando oito placas. Uma placa adicional foi arranjada com três genes controle: actina (SCESMY3008F10), fator de elongação $1 \alpha$ (SCESMY4002D07) e $\beta$-tubulina (SCESMY1003C03). Os insertos selecionados foram amplificados por PCR em solução contendo: tampão para reação PCR 1X (20 mM Tris-HCl pH 8,4 e 50 mM KCl); 0,2 mM de cada dNTP; 1 mM de $\mathrm{MgCl}_{2}$; 0,5 U de Taq DNA Polimerase (Fermentas); 10 ng de DNA; 5 pmol dos iniciadores universais M13F e M13R e água deionizada, esterilizada, para o volume final de 40 $\mu \mathrm{L}$. A reação foi feita nas seguintes condições: $95^{\circ} \mathrm{C}$ por 2 min e 30 ciclos de $95^{\circ} \mathrm{C}$ por 10 segundos, $50^{\circ} \mathrm{C}$ por 15 segundos, $60^{\circ} \mathrm{C}$ por 60 segundos. Os produtos amplificados foram quantificados por eletroforese em gel de agarose 1,0\% - TBE 0,5X, comparados com o padrão de massa "DNA low mass ladder" (Invitrogen) e purificados por precipitação com 1/10 de volume de 3 M de acetato de sódio (pH 5,5), 2 volumes de etanol 100\%, e centrifugados a $4000 \mathrm{~g}$ por 45 min a $4^{\circ} \mathrm{C}$. O pélete obtido foi lavado com $200 \mu \mathrm{L}$ de etanol $75 \%$ e seco durante 1 hora a temperatura ambiente. Os péletes foram solubilizados em água deionizada esterilizada para a concentração final de 50 ng DNA $\mu \mathrm{L}^{-1}$ e armazenado a $-20^{\circ} \mathrm{C}$ até o momento da impressão das membranas. Para a impressão das membranas, foram adicionados aos produtos amplificados uma solução de 0,4 N de $\mathrm{NaOH}$ para se obter a concentração final de 25 ng DNA $\mu \mathrm{L}^{-1}$ e $0,2 \mathrm{~N}$ de $\mathrm{NaOH}$. O DNA foi, então, desnaturado por 15 min a $37^{\circ} \mathrm{C}$ e impresso em membranas Hybond-N (Amersham Biosciences) com um carimbo manual composto por 96 agulhas (V\&P Scientific). Este carimbo deposita $0,1 \mu \mathrm{L}$ da solução de DNA na membrana, correspondendo a aproximadamente 2,5 ng de DNA. A impressão foi repetida 4 vezes para se atingir a quantidade de 10 ng de DNA por "spot". O conjunto de nove microplacas foi impresso em uma membrana de Hybond-N (80x115 mm), com uma configuração 3x3 (864 pontos). O DNA foi fixado nas 
membranas por UV em Stratalinker 2400 (Stratagene) por aproximadamente $1 \mathrm{~min}$ a $70 \mathrm{~mJ} \mathrm{~s}^{-1}$, e os filtros foram então armazenados à temperatura ambiente entre folhas de papel de filtro até o momento de uso.

\subsubsection{Preparo da sonda do vetor e hibridização (OverGO)}

Para determinar possíveis variações na quantidade de DNA depositada nas membranas para os diferentes pontos, foi feita uma hibridização das membranas com uma sonda de oligonucleotídeos que reconhece a seqüência entre os iniciadores M13F e T7 do vetor pSPORT1. Esta sonda foi sintetizada com os iniciadores 5'-GTGGTCCTGAACTTTATCCGC-3' e 5'-TAGACTGGATGGAGGCGGATAA-3' na presença de dCTP marcado com ${ }^{33} \mathrm{P}$, de acordo com o protocolo descrito por McPherson (2000). Para a síntese das sondas, os iniciadores foram misturados a uma concentração final de $10 \mu \mathrm{M}$ e desnaturados a $80^{\circ} \mathrm{C}$ por 5 min e em seguida incubados a $37^{\circ} \mathrm{C}$ por 10 min e imediatamente armazenadas em gelo. Após este procedimento, foi adicionada 5\% de solução de $2 \mathrm{mg}$ albumina de soro bovino (BSA) $\mathrm{mL}^{-1}$, 20\% de solução OLB (Apêndice 1), 5\% de $\alpha^{33} \mathrm{P}$-dCTP (1 mCi $100 \mu \mathrm{L}^{-1}$ ), $2 \mathrm{U}$ da enzima DNA polimerase I (Large Klenow Fragment) e 50\% de água deionizada esterilizada. Esta reação de marcação foi mantida à temperatura ambiente por 1 hora. As sondas marcadas foram purificadas em colunas Probe Quant G50 (Amersham Pharmacia) para a remoção dos nucleotídeos não incorporados, segundo as instruções do fabricante. As sondas purificadas foram desnaturadas a $94^{\circ} \mathrm{C}$ por 5 min antes da adição à solução de hibridização.

As membranas foram preparadas para a hibridização fazendo-se uma lavagem com solução fervente de 0,5\% de SDS por 5 min a temperatura ambiente. Depois, foi adicionada a solução de pré-hibridização (1\% de BSA; 1 mM de EDTA pH 8,0, 7\% de SDS e $500 \mathrm{mM}$ de $\mathrm{Na}_{2} \mathrm{HPO}_{4}$ ) e as membranas foram pré-hibridizadas a $50^{\circ} \mathrm{C}$ por 4 horas.

Após este período, a solução de pré-hibridização foi descartada e foi adicionada a solução de hibridização (1\% de BSA; 1 mM de EDTA pH 8,0, 7\% de SDS e $500 \mathrm{mM}$ de $\mathrm{Na}_{2} \mathrm{HPO}_{4}$ ) juntamente com as sondas desnaturadas. A hibridização foi feita por 18 horas a $50^{\circ} \mathrm{C}$.

Após este período, a solução de hibridização juntamente com as sondas marcadas foram descartadas e foram feitas duas lavagens com 2X SSC e 0,1\% SDS, mais duas lavagens com 1,5X SSC e $0,1 \%$ SDS e duas lavagens com $0,5 X$ SSC e $0,1 \%$ SDS, sendo que cada lavagem foi feita por $15 \min$ a $55^{\circ} \mathrm{C}$. 
Após as lavagens, as membranas foram utilizadas para sensibilizar filmes IP (Amersham Biosciences) por 48 horas, e as imagens das membranas foram adquiridas por densitometria utilizando-se um densitômetro Storm (Amersham Biosciences). Após a aquisição da imagem, as membranas foram lavadas com solução fervente de $0,1 \%$ de SDS por 15 min à temperatura ambiente por duas vezes e guardadas a $-20^{\circ} \mathrm{C}$ até a sua re-utilização.

\subsubsection{Preparo das sondas e hibridização}

As sondas foram sintetizadas com descrito por Nogueira et al. (2003). Trinta microgramas de RNA total foram submetidos à transcrição reversa com Superscript II (Invitrogen) usando um iniciador oligo-dT 18 (3 $\mu \mathrm{M})$, dCTP marcado com ${ }^{33} \mathrm{P}$ com atividade de $3000 \mathrm{Ci} \mathrm{mmol}^{-1}$ e dATP, dGTP e dTTP não marcados por 20 min a $42^{\circ} \mathrm{C}$. Após este período, foi adicionado dCTP nãomarcado na concentração final de $1 \mathrm{mM}$, e a reação prosseguiu por mais 1 hora a $42^{\circ} \mathrm{C}$. As sondas de cDNA foram purificadas utilizando microcolunas Probe Quant G-50, de acordo com as instruções do fabricante (Amersham Biosciences). As membranas foram inicialmente préhibridizadas por 2 horas utilizando uma solução de pré-hibridização (5X SSC, 20 mM de Tris$\mathrm{HCl}$ pH 7,5, 50\% de formamida deionizada, 10X Solução de Denhardt’s, 1\% de SDS e 1 mg de DNA de esperma de salmão).

Em seguida, a solução de pré-hibrização foi descartada e foi adicionada às membranas a solução de hibridização (5X SSC, 20 mM de Tris-HCl, pH 7,5, 50\% de formamida deionizada, 2X Solução de Denhardt's, 1\% de SDS, 5\% de Dextran e 1 mg de DNA de esperma de salmão) juntamente com a sonda purificada e desnaturada. A hibridização foi feita por $18 \mathrm{~h}$ a $42^{\circ} \mathrm{C}$. Após a hibridização, as membranas foram lavadas seqüencialmente com as seguintes soluções: 0,2X SSC com $0,5 \%$ SDS por $20 \mathrm{~min}$ a $58^{\circ} \mathrm{C}$ (2 vezes), $0,5 \mathrm{X}$ SSC com $0,5 \%$ SDS por $20 \mathrm{~min}$. a $58^{\circ} \mathrm{C}(2$ vezes) e $0,2 \mathrm{X}$ SSC com $0,5 \%$ SDS por 20 min a $58^{\circ} \mathrm{C}$ ( 2 vezes). em seguida as membranas foram utilizadas para sensibilizar filmes IP por 96 h. O sinal de hibridização foi detectado através de varredura, utilizando-se um densitômetro STORM (Amersham Biosciences).

\subsubsection{Análise estatística dos macroarranjos de cDNA}

As imagens das membranas foram quantificadas por densitometria utilizando-se o programa ImageQuant (Amersham Pharmacia). O reticulado separando os "spots” foi ajustados manualmente para o melhor reconhecimento dos mesmos. O sinal de hibridização foi 
quantificado individualmente, e o "background” foi subtraído automaticamente de cada ponto. Os dados de intensidade dos sinais de hibridização gerados foram organizados em planilhas do programa Microsoft Excel (Microsoft). As imagens das membranas hibridizadas com a sonda OverGO foram quantificadas da mesma maneira. Os dados de intensidade de cada ponto da membrana foram normalizados com base no sinal de hibridização com a sonda OverGO.

Posteriormente, os sinais de hibridização das diferentes membranas foram normalizados com base no sinal de hibridização total (somatória de todos os “spots”) das mesmas.

Os três genes controles foram comparados entre si para definir qual seria o melhor padrão a ser utilizado. Foi escolhido o gene codificando actina, pois este apresentou variação nãosignificativa entre os tratamentos. Os valores de intensidade do sinal de hibridização dos "spots" foram normalizados pela intensidade do sinal de hibridização do gene controle em cada subarranjo (9x9), conforme metodologia utilizada por Liu et al. (2003).

Para a comparação entre os tratamentos, os valores de intensidade do sinal de hibridização dos pontos foram reorganizados em planilhas do programa Microsoft Excel de forma pareada (apenas dois tratamentos por análise).

Para cada dupla de tratamentos, foram calculados a média de cada tratamento ( $\mu_{\text {trat1 }}$ e $\mu_{\text {trat2 }}$ ) e a variável A, representando a média de intensidade dos "spots” entre os tratamentos (eq. 3) e a variável M, representando a razão da intensidade dos “spots” entre os tratamentos (eq. 4). A comparação entre os tratamentos foi feita utilizando-se o teste t-student $(p<0,05)$.

$$
\begin{gathered}
A=\log _{2} \sqrt{\mu_{\text {trat } 1} \mu_{\text {trat } 2}} \\
M=\log _{2} \frac{\mu_{\text {trat } 1}}{\mu_{\text {trat } 2}}
\end{gathered}
$$

As variáveis A e M foram plotadas conforme descrito por Bowtell \& Sambrook (2002), com a modificação que os pontos que apresentaram diferença estatística significativa pelo teste tstudent são representados por cores diferentes no gráfico.

\subsection{Resultados}

\subsubsection{Colonização micorrízica}


Os resultados de porcentagem de colonização micorrízica intrarradicular são apresentados na Figura 1. As plantas não-inoculadas não apresentaram colonização micorrízica. As plantas inoculadas com Glomus clarum e cultivadas em condições de baixo fósforo apresentaram porcentagem de colonização micorrízica significativamente maior $(\mathrm{p}<0,05)$ do que aquelas cultivadas na condição de alto P. Em condições de baixo P, 8 semanas após o transplantio (SAT), raízes inoculadas com G. clarum, a porcentagem de colonização micorrízica foi 2,1 vezes maior do que em condições de alto P. Já, com 12 SAT a porcentagem de colonização micorrízica foi 5,5 vezes maior em condições de baixo $\mathrm{P}$ do que em condições de alto $\mathrm{P}$.

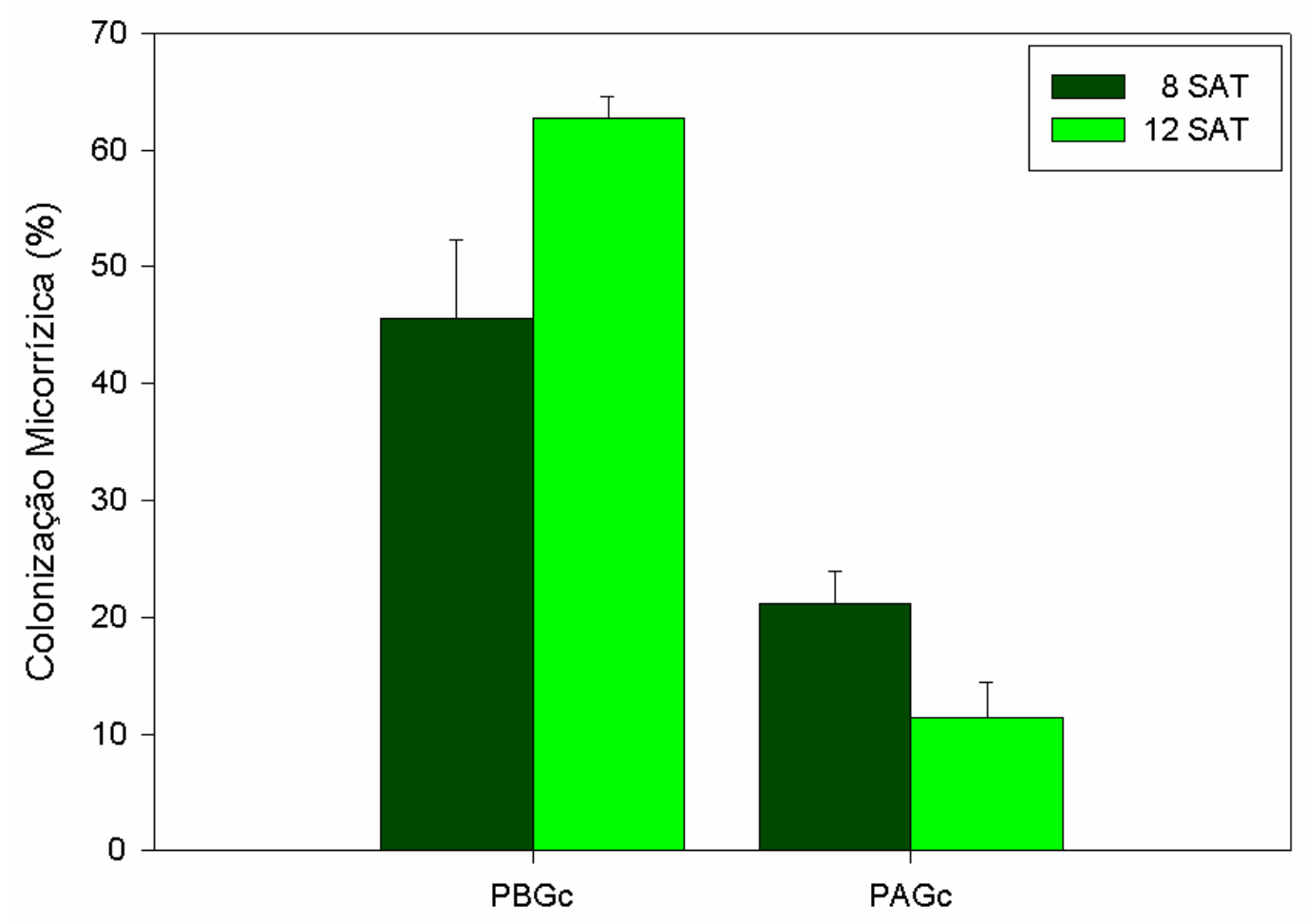

Figura 1 - Porcentagem de colonização micorrizica em raízes de cana-de-açúcar inoculadas com Glomus clarum (Gc) e cultivadas com 20 (PB) ou 200 (PA) mg P kg-1 de substrato. As plantas foram colhidas 8 ou 12 semanas após o transplantio (SAT). Os dados são médias de 10 repetições. As barras representam o desvio padrão da média

\subsubsection{Biomassa vegetal e nutrientes na parte aérea}


A inoculação com os fungos micorrízicos não afetou significativamente a produção de biomassa pelas plantas utilizadas neste experimento (teste Tukey, $\mathrm{p}<0,05$ ). Também não foram observadas diferenças significativas entre a massa da matéria seca da parte aérea das plantas adubadas com $200 \mathrm{mg}$ de P (alto P) e aquelas adubadas com 20 mg de P (baixo P) (teste Tukey, $\mathrm{p}<0,05$ ) (Tabelas 1 e 2).

As concentrações de macro e micronutrientes na parte aérea também são mostradas nas Tabelas 1 e 2.

Tabela 1 - Biomassa aérea e concentração de nutrientes na parte aérea de plantas de cana-deaçúcar, não-inoculadas (Ni) ou inoculadas com G. clarum (Gc) e cultivadas durante 8 semanas em vasos contendo 20 (PB) ou $200 \mathrm{mg} \mathrm{P} \mathrm{kg}^{-1}$ de substrato (PA)

\begin{tabular}{ccrrrr}
\hline \multicolumn{2}{c}{ Variável } & \multicolumn{4}{c}{ Tratamentos } \\
\cline { 3 - 6 } Biomassa & $(\mathrm{g})$ & $11,1 \pm 1,9$ & $11,3 \pm 1,8$ & $10,0 \pm 2,2$ & $11,9 \pm 1,0$ \\
$\mathrm{~N}$ & $\left(\mathrm{~g} \mathrm{~kg}^{-1}\right)$ & $11,6 \pm 1,0$ & $10,6 \pm 1,4$ & $12,7 \pm 2,7$ & $11,8 \pm 1,7$ \\
$\mathrm{P}$ & $\left(\mathrm{g} \mathrm{kg}^{-1}\right)$ & $0,9 \pm 0,1$ & $1,0 \pm 0,1$ & $4,7 \pm 1,3$ & $4,5 \pm 0,5$ \\
$\mathrm{~K}$ & $\left(\mathrm{~g} \mathrm{~kg}^{-1}\right)$ & $14,2 \pm 1,9$ & $16,8 \pm 2,4$ & $16,3 \pm 3,2$ & $15,0 \pm 3,2$ \\
$\mathrm{Ca}$ & $\left(\mathrm{g} \mathrm{kg}^{-1}\right)$ & $1,3 \pm 0,7$ & $1,3 \pm 0,3$ & $1,9 \pm 0,4$ & $1,5 \pm 0,5$ \\
$\mathrm{Mg}$ & $\left(\mathrm{g} \mathrm{kg}^{-1}\right)$ & $3,5 \pm 0,7$ & $3,9 \pm 0,6$ & $4,6 \pm 1,0$ & $4,2 \pm 0,9$ \\
$\mathrm{~S}$ & $\left(\mathrm{~g} \mathrm{~kg}^{-1}\right)$ & $2,2 \pm 0,2$ & $2,5 \pm 0,2$ & $2,7 \pm 0,6$ & $2,6 \pm 0,5$ \\
$\mathrm{~B}$ & $\left(\mathrm{mg} \mathrm{kg}^{-1}\right)$ & $44,6 \pm 5,5$ & $41,0 \pm 7,4$ & $43,8 \pm 9,0$ & $39,9 \pm 2,7$ \\
$\mathrm{Cu}$ & $\left(\mathrm{mg} \mathrm{kg}^{-1}\right)$ & $3,6 \pm 1,1$ & $5,0 \pm 1,1$ & $5,9 \pm 1,4$ & $5,7 \pm 1,1$ \\
$\mathrm{Fe}$ & $\left(\mathrm{mg} \mathrm{kg}^{-1}\right)$ & $147,9 \pm 96,3$ & $285,6 \pm 207,4$ & $349,5 \pm 204,1$ & $259,3 \pm 102,7$ \\
$\mathrm{Mn}$ & $\left(\mathrm{mg} \mathrm{kg}^{-1}\right)$ & $171,9 \pm 39,6$ & $180,1 \pm 51,2$ & $193,8 \pm 33,1$ & $148,3 \pm 34,9$ \\
$\mathrm{Zn}$ & $\left(\mathrm{mg} \mathrm{kg}^{-1}\right)$ & $37,3 \pm 7,6$ & $42,2 \pm 14,0$ & $32,6 \pm 7,1$ & $25,5 \pm 4,2$ \\
\hline
\end{tabular}

Os dados representam a média de 10 repetições \pm desvio padrão da média 
Tabela 2 - Biomassa aérea e concentração de nutrientes na parte aérea de plantas de cana-deaçúcar, não-inoculadas (Ni) ou inoculadas com G. clarum (Gc) e cultivadas durante 12 semanas em vasos contendo 20 (PB) ou $200 \mathrm{mg} \mathrm{P} \mathrm{kg}^{-1}$ de substrato (PA)

\begin{tabular}{|c|c|c|c|c|c|}
\hline \multirow{2}{*}{\multicolumn{2}{|c|}{ Variável }} & \multicolumn{4}{|c|}{ Tratamentos } \\
\hline & & PBNi & PBGC & PANi & PAGc \\
\hline Biomassa & (g) & $20,1 \pm 2,9$ & $19,9 \pm 1,3$ & $17,6 \pm 4,3$ & $19,2 \pm 2,0$ \\
\hline $\mathrm{N}$ & $\left(\mathrm{g} \mathrm{kg}^{-1}\right)$ & $11,1 \pm 1,0$ & $12,4 \pm 2,1$ & $11,5 \pm 1,3$ & $11,4 \pm 1,2$ \\
\hline $\mathrm{P}$ & $\left(\mathrm{g} \mathrm{kg}^{-1}\right)$ & $1,0 \pm 0,1$ & $1,0 \pm 0,1$ & $4,7 \pm 0,2$ & $4,7 \pm 0,5$ \\
\hline K & $\left(\mathrm{g} \mathrm{kg}^{-1}\right)$ & $13,9 \pm 2,5$ & $14,6 \pm 2,5$ & $14,0 \pm 2,9$ & $13,5 \pm 2,4$ \\
\hline $\mathrm{Ca}$ & $\left(\mathrm{g} \mathrm{kg}^{-1}\right)$ & $1,3 \pm 0,1$ & $1,1 \pm 0,2$ & $1,4 \pm 0,2$ & $1,5 \pm 0,2$ \\
\hline $\mathrm{Mg}$ & $\left(\mathrm{g} \mathrm{kg}^{-1}\right)$ & $4,2 \pm 0,6$ & $4,4 \pm 0,6$ & $4,0 \pm 0,3$ & $4,2 \pm 0,7$ \\
\hline$S$ & $\left(\mathrm{~g} \mathrm{~kg}^{-1}\right)$ & $2,1 \pm 0,3$ & $2,5 \pm 0,2$ & $2,3 \pm 0,3$ & $2,4 \pm 0,2$ \\
\hline B & $\left(\mathrm{mg} \mathrm{kg}^{-1}\right)$ & $46,9 \pm 4,9$ & $42,1 \pm 2,6$ & $38,7 \pm 9,1$ & $38,9 \pm 2,9$ \\
\hline $\mathrm{Cu}$ & $\left(\mathrm{mg} \mathrm{kg}^{-1}\right)$ & $4,6 \pm 0,9$ & $6,3 \pm 0,9$ & $6,0 \pm 0,7$ & $6,5 \pm 1,1$ \\
\hline $\mathrm{Fe}$ & $\left(\mathrm{mg} \mathrm{kg}^{-1}\right)$ & $236,0 \pm 79,9$ & $201,8 \pm 35,1$ & $243,8 \pm 179,1$ & $385,6 \pm 76,8$ \\
\hline Mn & $\left(\mathrm{mg} \mathrm{kg}^{-1}\right)$ & $193,4 \pm 27,2$ & $203,8 \pm 30,4$ & $164,1 \pm 18,4$ & $154,2 \pm 32,4$ \\
\hline $\mathrm{Zn}$ & $\left(\mathrm{mg} \mathrm{kg}^{-1}\right)$ & $32,6 \pm 6,5$ & $46,4 \pm 11,9$ & $29,0 \pm 4,5$ & $24,4 \pm 4,4$ \\
\hline
\end{tabular}

Os dados representam a média de 10 repetições \pm desvio padrão da média.

\subsubsection{Biblioteca subtrativa supressiva}

\subsubsection{Construção da biblioteca subtrativa supressiva}

Após a síntese da segunda fita de cDNA, o mesmo foi digerido com a enzima de restrição RsaI. Na figura 2A, pode-se observar o aumento da concentração de fragmentos de menor massa molecular nas amostras tratadas com RsaI. O cDNA digerido com RsaI foi utilizado para a ligação dos adaptadores e para as reações de PCR subtrativo supressivo (Figura 2B). Os produtos obtidos a partir da reação de PCR subtrativo foram clonados em pGEM-T-easy (Promega) e seqüenciados. Os tamanhos dos insertos variaram de 200 a 800 pb.

\subsubsection{Descrição da biblioteca subtrativa supressiva}

A biblioteca subtrativa supressiva foi sintetizada utilizando-se como "tester” o cDNA extraído de raízes micorrizadas cultivadas em condições de baixo P por 12 semanas. Foram seqüenciados 288 clones e as seqüências tiveram a análise de qualidade feita no programa Phred, o qual selecionou as seqüências que apresentaram pelo menos 300 bases com qualidade $>20$. Um total de 108 clones apresentaram a qualidade mínima para as análises posteriores. Esta biblioteca apresentou Índice de Novidade de $9 \%$, de forma que a cada 10 seqüências obtidas apenas 1 é 
nova para este banco de dados. Esta biblioteca apresentou alta redundância pois mais de 20\% dos clones seqüenciados foram agrupados em grupos formados por mais de 4 seqüências (reads). Este dado é importante para que possamos entender a ausência de genes raros, pois, aparentemente, a estratégia de construção de biblioteca subtrativa supressiva enriquece as populações de cDNA com genes com maior nível de expressão e provavelmente exclui genes com baixo nível de expressão.

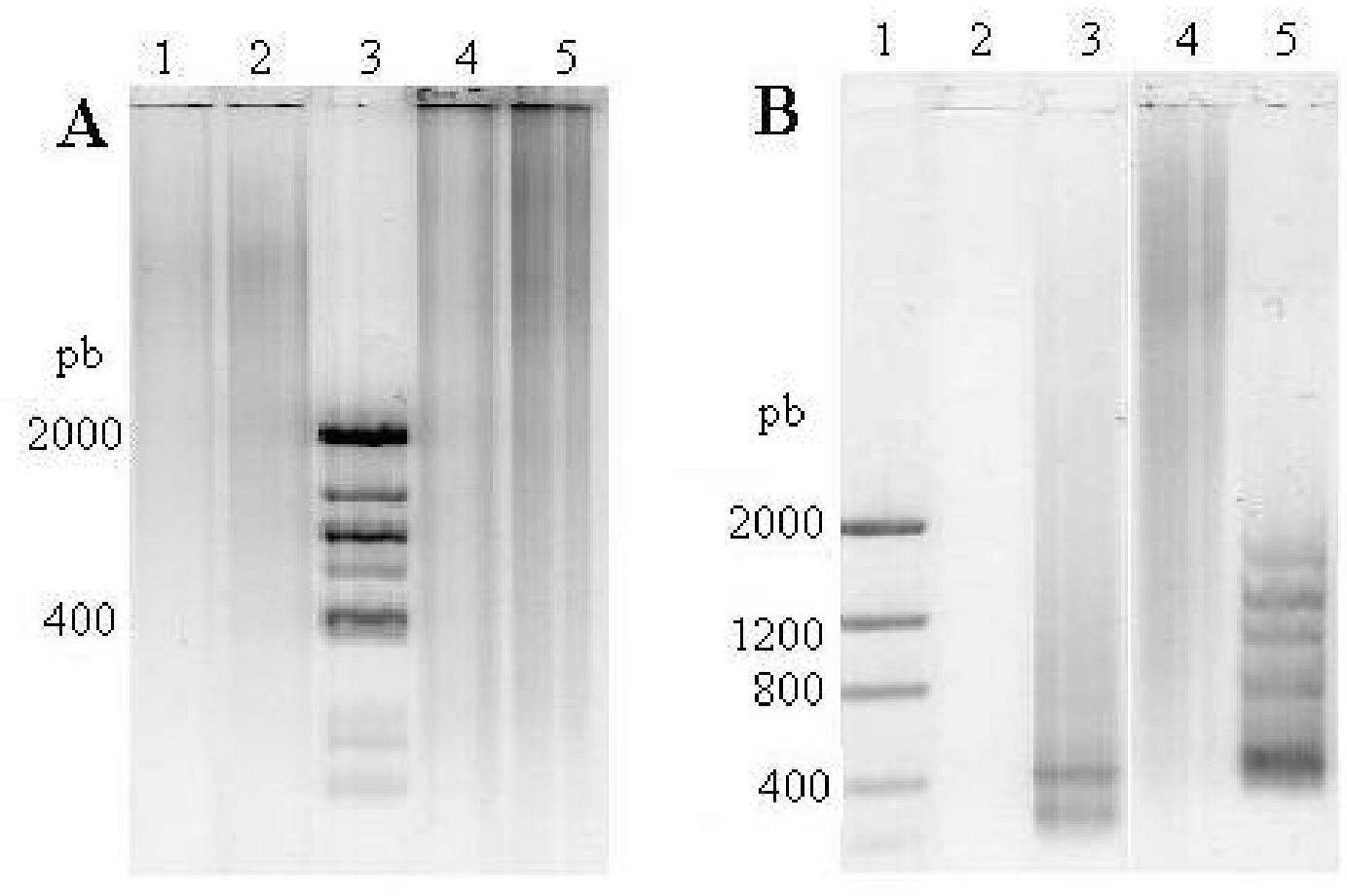

Figura 2 - Eletroforese dos cDNAs de raízes de cana-de-açúcar de diferentes tratamentos em gel de agarose 1,0\%. A: cDNAs antes e depois da digestão com a enzima RsaI. 1: Baixo $\mathrm{P}$, não-inoculado, 12 semanas após o transplantio (PBNi12s), antes da digestão com RsaI. 2: Baixo P, inoculado com Glomus clarum, 12 semanas após o transplantio (PBGc12s), antes da digestão com RsaI. 3: Marcador de Massa Molecular "Low Mass DNA marker”. 4: PBNi12s depois da digestão com RsaI. 5: PBGc12s depois da digestão com RsaI. B: Produtos da PCR subtrativa supressiva. 1: Marcador de Massa Molecular “Low Mass DNA marker”. 2: Controle negativo. 3: “Tester” PBGc12s. 4: “Tester” PBNi12s. 5: Controle positivo (músculo humano)

As seqüências obtidas foram comparadas automaticamente com a base de dados do NCBI e manualmente com a base de dados do SUCEST (Anexo 2). A análise dos dados revelou a 
presença de genes com alta similaridade a genes codificando proproteína convertase, metalotioneína $2 b$, sinapsina I, cafeoil-CoA-O-metiltransferase, fator de elongação $1 \alpha$ e $\beta$ tubulina. Três seqüências foram encontradas apenas na base de dados do NCBI: Ac1147 (representada duas vezes) e rRNA intron codificando uma endonuclease.

Os genes identificados podem representar genes com expressão induzido em raízes micorrizadas em condições de baixo P. Para testar esta hipótese, os cDNAs codificando esses genes foram amplificados e utilizados para análises de expressão por hibridização em macroarranjos de cDNA.

\subsubsection{Bibliotecas de cDNA}

\subsubsection{Construção das bibliotecas de cDNA}

O rendimento da extração de RNA total das raízes de cana-de-açúcar foi de $20 \mu \mathrm{g}$ de RNA $\mathrm{g}^{-1}$ de tecido, em média. Na tabela 4, são apresentadas as quantidades totais de RNA utilizadas para a síntese das bibliotecas de cDNA e as razões entre as absorbâncias das soluções de RNA a $260 \mathrm{~nm}$ e $280 \mathrm{~nm}$.

Tabela 3. Quantidade e qualidade do RNA total utilizado para a construção das bibliotecas de cDNA

\begin{tabular}{cccc}
\hline Biblioteca & Tratamento & Quantidade de RNA total (mg) & $\mathrm{A}_{260} / \mathrm{A}_{280}$ \\
\hline MY1 & PBGc8s & 1,257 & 1,79 \\
MY2 & PBNi8s & 1,348 & 1,91 \\
MY3 & PANi8s & 0,848 & 1,72 \\
MY4 & PAGc8s & 1,500 & 1,65 \\
\hline
\end{tabular}

Para confirmar a integridade do RNA e determinar a ocorrência de possíveis contaminações por DNA genômico, os RNAs foram analisados por eletroforese em géis de agarose $1,2 \%$. Na Figura 3A, são apresentados exemplos de RNA total extraído de raízes de cana-de-açúcar. Na Figura 3B, são apresentadas amostras de RNA poliA ${ }^{+}$purificado com o kit Oligotex (Quiagen).

$\mathrm{O}$ RNA poliA ${ }^{+}$purificado foi utilizado para a síntese de cDNAs marcados com $\alpha-{ }^{32} \mathrm{P}-$ dCTP. Este cDNAs foram digeridos com a enzima SalI e os produtos das digestões fracionados por cromatografia em coluna de Sephadex. A seleção das frações utilizadas para clonagem foi feita com base no tamanho dos fragmentos de cDNA determinados por gel de agarose 1\% (Figura 
3C). Somente as frações que apresentaram os fragmentos de maior tamanho foram utilizadas para ligação ao vetor pSPORT (Invitrogen).

As bibliotecas foram validadas pela quantificação de clones recombinantes, através da digestão do DNA plasmidial de alguns clones com a enzima de restrição PvuII (Figura 3D). A presença de fragmentos de 400pb representa clones com vetor não-recombinante. Os fragmentos com tamanho de 4000pb representam o plasmídeo pSPORT linearizado, os fragmentos com tamanho maior que 1000pb representam insertos de cDNA com tamanho mínimo de 600 bases.

A
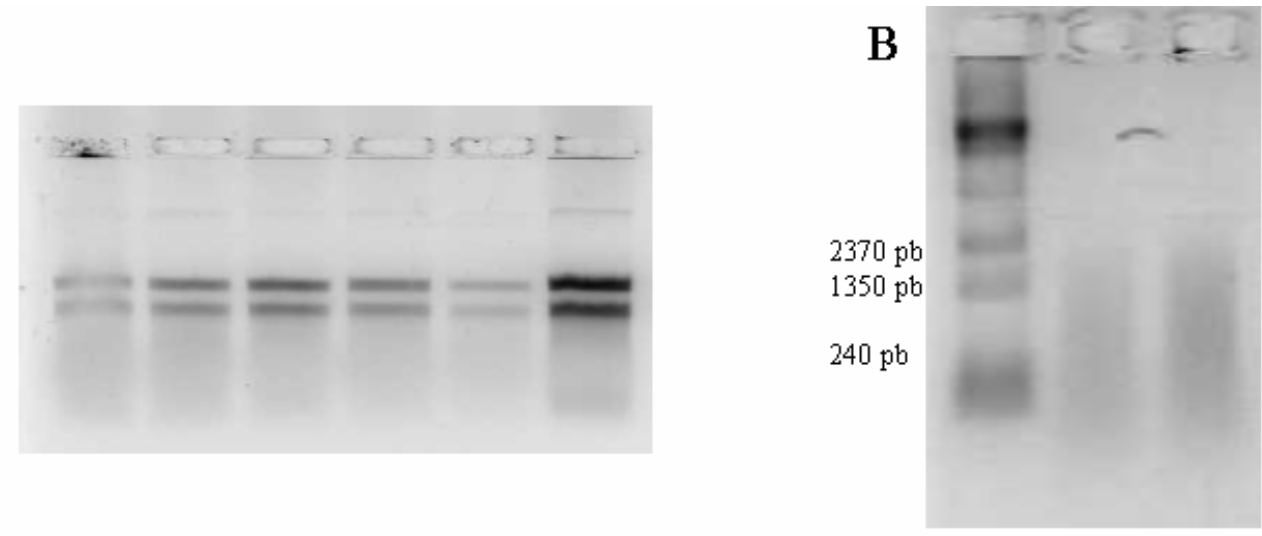

$\mathrm{C}$

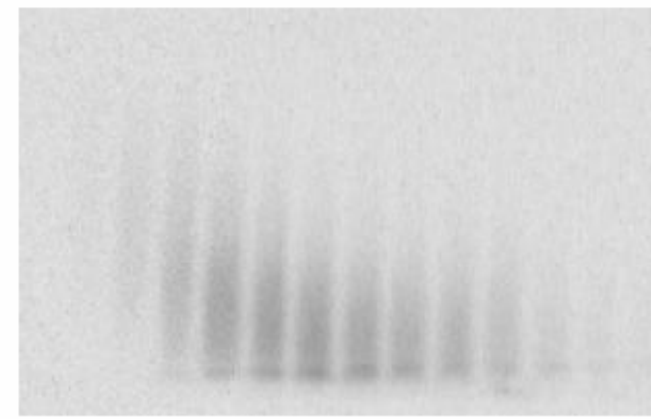

D

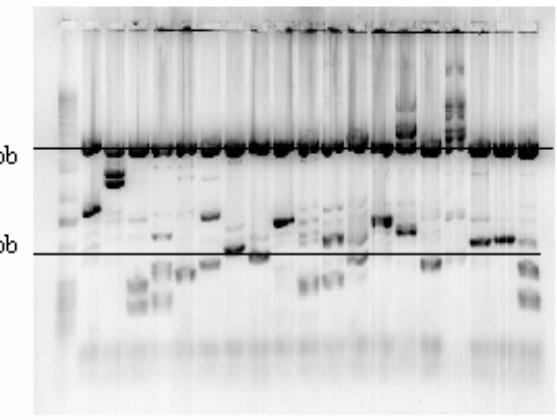

Figura 3 - Etapas da construção de bibliotecas de cDNA. A: RNA total extraído de raízes de cana-de-açúcar. B: RNA poliA ${ }^{+}$purificado a partir do RNA total. C: Frações de cDNAs purificados por cromatografia em coluna de Sepharose após vários tempos de eluição. D: Validação da biblioteca pela digestão de DNA plasmidial de clones escolhidos aleatoriamente com PvuII (4000pb representa o plasmídeo linearizado). Fragmentos com 1000pb representam insertos de cDNA com tamanho mínimo de 600 bases 


\subsubsection{Descrição das bibliotecas de cDNA}

A Tabela 4 resume as características das bibliotecas e os dados de seu seqüenciamentos. Antes do seqüenciamento, foi feita a avaliação da média do tamanho dos insertos pela restrição dos vetores com a enzima PvuII. Foram avaliados 96 clones escolhidos aleatoriamente de cada biblioteca e todas apresentaram no mínimo 70\% de clones recombinantes. Este índice de 70\% de clones recombinantes permitiu o início do seqüenciamento em larga escala das bibliotecas. Foram seqüenciados 2880 clones no total. O seqüenciamento foi feito a partir da região 5' do inserto, para evitar o seqüenciamento da região correspondente a cauda poliA presente nos mRNAs.

Tabela 4 - Características das bibliotecas de cDNA sintetizadas

\begin{tabular}{cccccc}
\hline $\begin{array}{c}\text { Nome da } \\
\text { biblioteca }\end{array}$ & $\begin{array}{c}\text { Média do tamanho } \\
\text { dos insertos (pb) }\end{array}$ & $\begin{array}{c}\text { Clones } \\
\text { sequenciados }\end{array}$ & $\begin{array}{c}\text { Reads } \\
\text { válidos }\end{array}$ & $\begin{array}{c}\text { Índice de } \\
\text { sucesso (\%) }\end{array}$ & $\begin{array}{c}\text { Índice de } \\
\text { novidade (\%) }\end{array}$ \\
\hline PBNi (MY2) & 1200 & 672 & 484 & 72 & 81 \\
PBGc (MY1) & 1000 & 672 & 417 & 62 & 92 \\
PANi (MY3) & 800 & 864 & 550 & 63 & 94 \\
PAGc (MY4) & 1350 & 672 & 352 & 54 & 89 \\
\hline Total & 1100 & 2880 & 1803 & 63 & 87 \\
\hline
\end{tabular}

Do conjunto de seqüências foi feita a remoção de seqüências do vetor, de seqüências de baixa qualidade (qualidade Phred < 20) e de seqüências representando rRNA. Foram consideradas válidas e utilizadas para as análises posteriores 1803 seqüências, representando um índice de sucesso de 63\% para o projeto como um todo. Este índice de sucesso, inicialmente parece baixo quando comparado com o obtido pelo projeto SUCEST (81,56\%) (Vettore et al., 2001). No entanto, nesse projeto (MycSUCEST) utilizou-se critérios mais restritivos para o aproveitamento de seqüências (reads) para o agrupamento. Enquanto o projeto SUCEST definiu reads válidos como tendo um mínimo de 140 bases com qualidade Phred $\geq 20$, neste trabalho definiu-se o read válido com no mínimo 300 bases com qualidade Phred $\geq 20$.

As seqüências válidas foram comparadas entre si e agrupadas em clusters utilizando-se o programa CAP3. O procedimento de agrupamento pelo CAP3 utilizado neste trabalho também diferiu daquele utilizado pelo projeto SUCEST (Telles \& Silva, 2001). O critério para agrupamento utilizado no MycSUCEST foi de 30 bases com $90 \%$ de similaridade entre as 
seqüências, enquanto o projeto SUCEST utilizou o padrão do programa CAP3 (40 bases com 80\% de similaridade entre as seqüências).

Na Figura 4, está representada a freqüência relativa de "clusters” em relação ao tamanho dos “clusters” gerados em cada biblioteca.

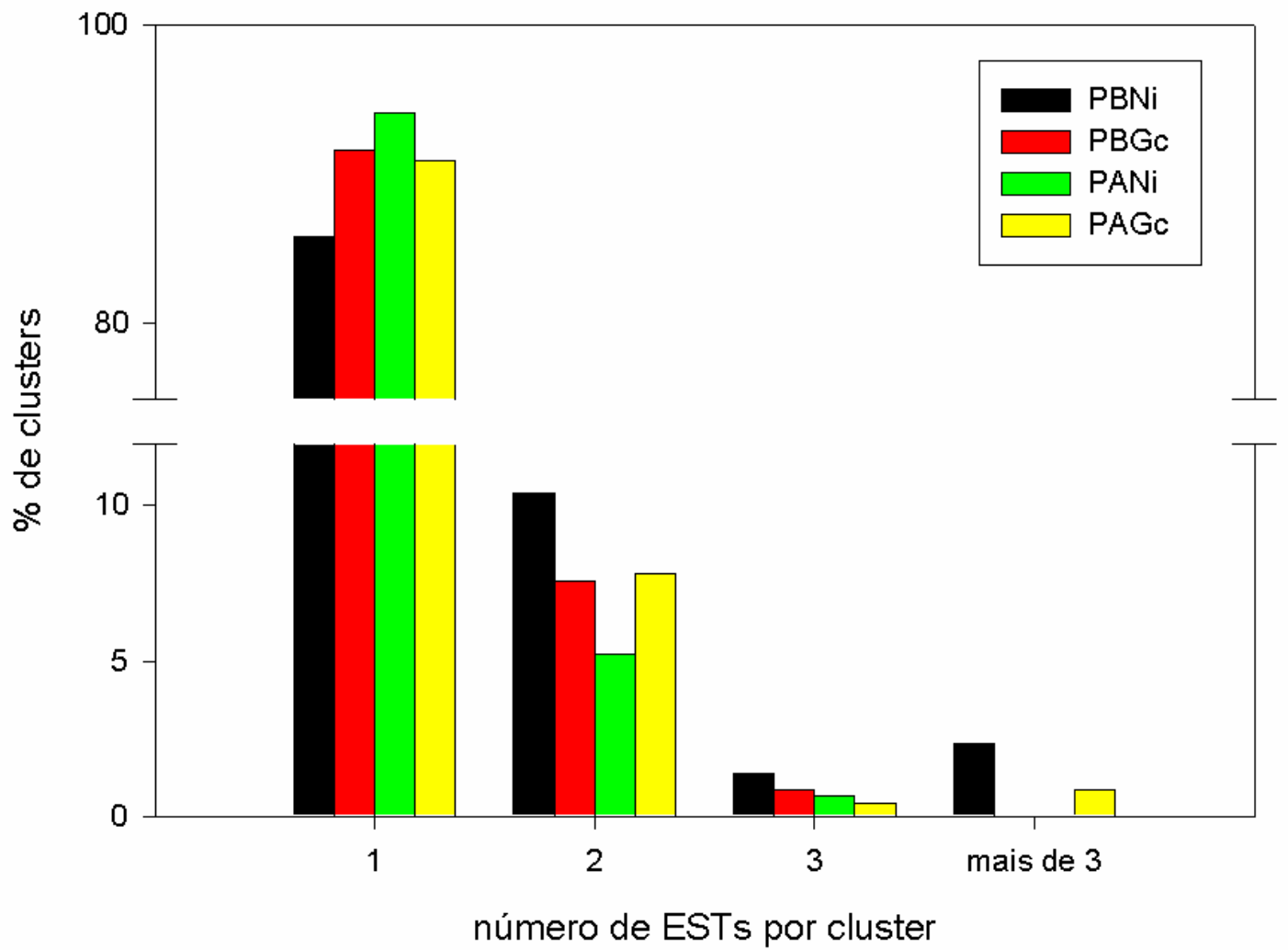

Figura 4 - Freqüência relativa de cluster com diferentes números de ESTs

\subsubsection{Classificação das ESTs}

Os clusters de ESTs e singletons identificados neste estudo foram classificados de acordo com sua função biológica nas categorias descritas pelo SUCEST, sendo elas: (1) metabolismo de aminoácidos, (2) bioenergética, (3) comunicação celular/transdução de sinais, (4) dinâmica celular, (5) metabolismo de DNA, (6) metabolismo de lipídios, ácidos graxos e isoprenóides, (7) elementos genéticos móveis, (8) metabolismo de nucleotídeos, (9) metabolismo de N, P e S, (10) crescimento vegetal e desenvolvimento, (11) metabolismo de proteínas, (12) metabolismo de 
RNA e transcrição, (13) metabolismo secundário, (14) armazenamento de proteínas, (15) respostas ao estresse, (16) transporte, (17) proteína putativa, (18) incapaz de classificar. Foram ainda adicionadas duas categorias para a classificação das ESTs que não apresentaram similaridade com seqüências do banco de dados do SUCEST, sendo elas: (19) similaridade somente no NCBI, o qual compreende as ESTs que apresentaram similaridade significativa com seqüências do banco NCBI mas não apresentaram similaridade significativa com ESTs do banco de dados do SUCEST e (20) similaridades não-significativas a qual compreende as ESTs com baixa similaridade (E-value superior a $10^{-5}$ ) com os a seqüências dos bancos de dados do NCBI ou do SUCEST. As freqüências relativa dos “clusters” e singletons em cada categoria, são mostradas na Figura 4.

As bibliotecas que apresentaram maior quantidade de clusters e singletons na categorias NCBI foram as bibliotecas PBGc (43,8\%) e PAGc (52,6\%). Estas duas bibliotecas foram construídas a partir de raízes colonizadas por G. clarum, e estas ESTs podem representar genes de fungos micorrízicos ou genes de cana-de-açúcar codificando micorrizinas (proteínas sintetizadas apenas durante a associação micorrízica). 


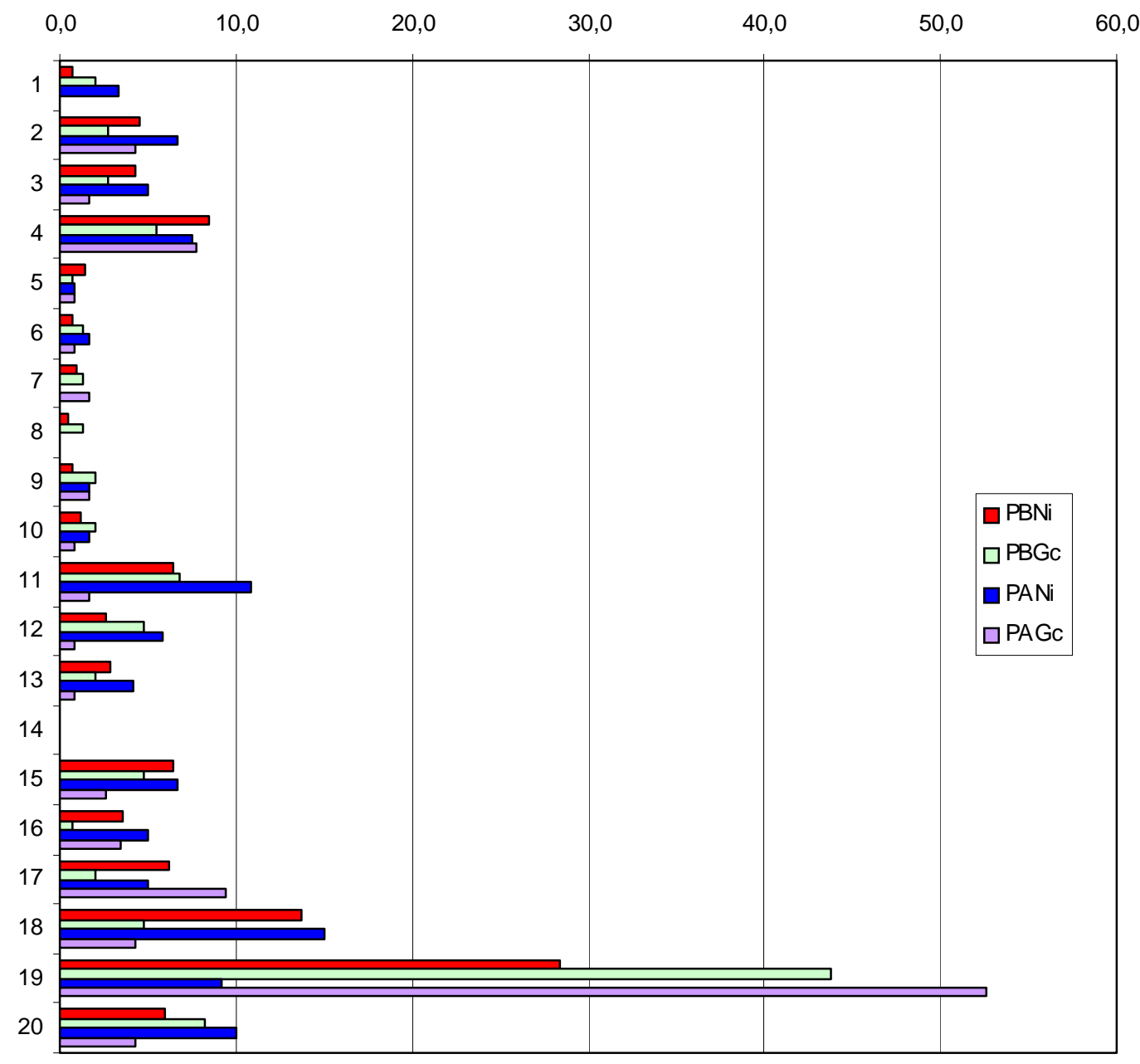

Figura 5 - Categorização das ESTs identificadas nas bibliotecas de cDNAs analisadas. Freqüências nas categorias: (1) metabolismo de aminoácidos, (2) bioenergética, (3) comunicação celular/transdução de sinais, (4) dinâmica celular, (5) metabolismo de DNA, (6) metabolismo de lipídios, ácidos graxos e isoprenóides, (7) elementos genéticos móveis, (8) metabolismo de nucleotídeos, (9) metabolismo de N, P e S, (10) crescimento vegetal e desenvolvimento, (11) metabolismo de proteínas, (12) metabolismo de RNA e transcrição, (13) metabolismo secundário, (14) armazenamento de proteínas, (15) respostas ao estresse, (16) transporte, (17) proteína putativa, (18) incapaz de classificar, (19) similaridade somente no NCBI, (20) similaridades não-significativas 


\subsubsection{Análise da expressão gênica em Northern blot eletrônico}

A cana-de-açúcar é uma das poucas espécies vegetais, juntamente com Arabidopsis thaliana, Medicago truncatula e Oryza sativa, para a qual existe um banco de dados de ESTs oriundo do seqüenciamento em larga escala de diversas bibliotecas de cDNA, sintetizadas a partir de diferentes tecidos e estádios fisiológicos (Vettore, 2003). Assim é possível determinar alterações no transcritoma a partir da freqüência de ESTs codificando genes de interesse em diferentes bibliotecas de cDNA.

Todos os “clusters” formados por no mínimo 2 “reads” foram utilizados para a análise de alterações de transcritoma de raízes de cana-de-açúcar através de Northern blots eletrônicos. Os “clusters” de ESTs foram agrupados em regulons (conjunto de genes potencialmente coregulados) de acordo com o seu perfil de expressão (Figura 6) nas diferentes bibliotecas. Esta análise também apontou perfis de expressão semelhantes entre as bibliotecas, permitindo a discriminação de bibliotecas sintetizadas a partir de mRNAs provenientes de raízes micorrizadas e não micorrizadas. Ou seja, o efeito da micorrização sobre o transcritoma das raízes de cana-deaçúcar foi maior do que o do P.

Baseando-se nos perfis de expressão in silico determinados pela abundância de ESTs nas diferentes bibliotecas foi possível distinguir pelo menos quinze regulons.

O regulon 1 é formado por apenas um gene que codifica uma desidrogenase citossólica putativa de 6-fosfoglucanato (SCESMY2004F02) que foi fracamente induzida em plantas nãoinoculadas cultivadas em condições de baixo $\mathrm{P}$.

O regulon 2 é composto por um único gene que codifica uma proteína hipotética (SCESMY1002A10) com expressão apenas em raízes micorrizadas, sendo que sua expressão é maior em plantas cultivadas em baixo $P$.

O regulon 3 é composto por quatro genes induzidos pela colonização micorrízica em condições de baixo $\mathrm{P}$, os quais são similares a regulador de transcrição da família LysR (SCESMY1001B02), sistema de transporte de açúcar tipo ABC (SCESMY1001H02), acil-CoAdesidrogenase (SCESMY1003F06) e desidrogenase dependente de FAD (SCESMY1003A05). 


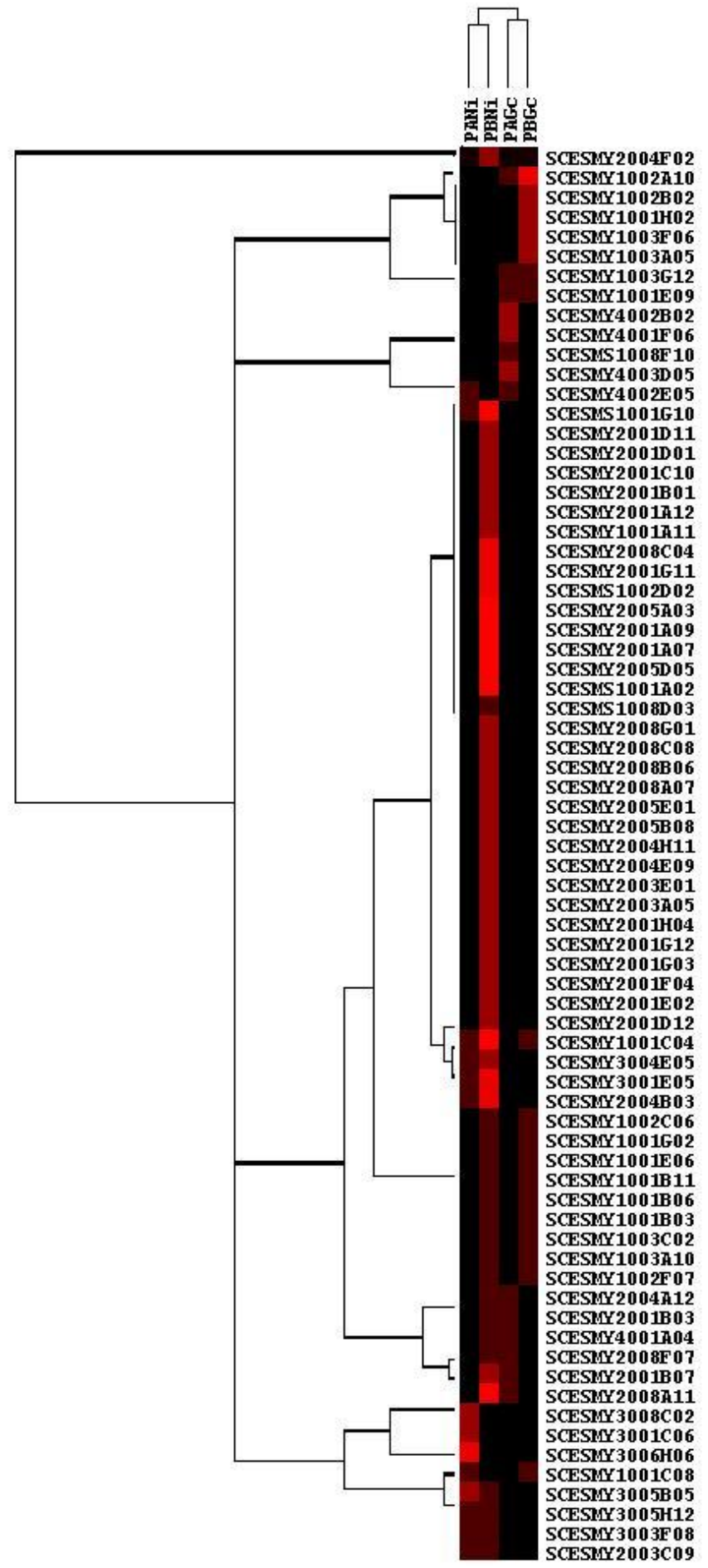

Figura 6 - Perfil de expressão em Northern blots eletrônicos de ESTs isoladas de raízes de cana-de-açúcar inoculadas com Glomus clarum e cultivadas com 20 (PB) ou 200 (PA) $\mathrm{mg} \mathrm{P} \mathrm{kg}^{-1}$ de substrato 
O regulon 4 é composto por dois genes induzidos pela colonização micorrízica independentemente da dose de $\mathrm{P}$ aplicada, os quais são similares a aminotransferase aromática aspartato/tirosina (SCESMY1003G12) e simporte $\mathrm{H}^{+}$/gluconato (SCESMY1001E09). Aspartato aminotransferases são induzidas em nódulos e raízes micorrizadas de M. truncatula (Manthey et al., 2004).

O regulon 5 é composto por quatro genes induzidos pela colonização micorrízica em condições de alto P, os quais são similares a: proteína hipotética (SCESMY4002B02), quinase de histidina (SCESMY4001F06), metalotioneína 2b (SCESMS1008F10) e proteína hipotética (SCESMY4003D05).

O regulon 6 é composto por um único gene que codifica uma quinase de histidina (SCESMY4002E05) que é induzida pela alta dose de P independente da presença do FMA.

O regulon 7 é composto por 32 genes com expressão induzida em raízes não-inoculadas e cultivadas em condições de baixo P, os quais são similares a endonuclease (SCESMY1001G10), cinamoil-CoA-redutase (SCESMY2001D11), monoxigenase do citocromo P450 (SCESMY2001C10 e SCESMY2005A03), metalotioneína 1 (SCESMY2001G12), metalotioneína 2 (SCESMY2005D05), metalotioneína 3 (SCESMY2001A12), proteína de secreção/ativação de hemolisina, proteína específica de raiz (SCESMY2008C04), proteína ribossomal S60 L13 (SCESMY1002D02), proteína putativa associada a senescência (SCESMY2001A07), proteína de ligação a guanidina (SCESMY2008C08), citocromo C-oxidase III (SCESMY2008A07), proteína de ligação a RNA (SCESMY2005B08), peroxidase de ascorbato citossólica (SCESMY2004H11), proteína induzida por estresse hídrico (SCESMY2003E01), proteína rica em glicina (SCESMY2003A05), fator de elongação $1 \gamma$ (SCESMY2001H04), proteína 82 de choque térmico (SCESMY2001G03), $\alpha$-tubulina (SCESMY2001F04), hidroxilase de ácido graxo (SCESMY2001E02), calnexina (SCESMY2001D12) e dez proteínas hipotéticas (SCESMY2001D01, SCESMY2001B01, SCESMY2001G11, SCESMY2001A09, SCESMS1001A02, SCESMS1008D03, SCESMY2008G01, SCESMY2008B06, SCESMY2005E01 e SCESMY2004E09).

O regulon 8 é composto por um único gene que codifica um fator de iniciação de tradução (SCESMY1001C04) que é suprimido em raízes inoculadas e cultivadas em alto P, apresenta expressão moderada em raízes não-inoculadas cultivadas em alto $\mathrm{P}$ e em raízes inoculadas cultivadas em baixo P e é fortemente induzido em raízes não-inoculadas cultivadas em baixo P. 
O regulon 9 é composto por três genes induzidos apenas em raízes não-micorrizadas sendo fortemente expressos em condições de baixo P, os quais são similares a S-adenosilmetionina sintase 2 (SCESMY3004E05), proteína rica em leucina de ligação ao RNA (SCESMY3001E05) e metalotioneína (SCESMY2004B03).

O regulon 10 é composto por nove genes induzidos em condições de baixo P independente da presença de FMAs, os quais são similares a quinase de histidina (SCESMY1002C06), permeases (SCESMY1001G02 e SCESMY1001B11), quinase de serina/treonina (SCESMY1001E06), oxidoredutase (SCESMY1001B06), proteína hipotética (SCESMY1001B03), transportador de fosfato ABC (SCESMY1003C02), transportador de xilose ABC (SCESMY1003A10) e fator de elongação 1 $\alpha$ (SCESMY1002F07).

O regulon 11 é composto por quatro genes que são induzidos pela micorrização em condições de baixo P e pela adubação com alto $\mathrm{P}$ em plantas não-micorrizadas, os quais são similares a colagenase (SCESMY2004A12), proteína de ligação a mirosinase (SCESMY2001B03), $\alpha$-tubulina (SCESMY4001A04) e translocase de ATP/ADP (SCESMY2008F07).

O regulon 12 é composto por dois genes que são induzidos em PBNi e com menor acúmulo em PAGc, os quais são similares a epimerase (SCESMY2001B07) e metalotioneína 2 (SCESMY2008A11).

O regulon 13 é composto três genes induzidos em condições de alto $\mathrm{P}$ independente da micorrização, os quais são similares a sintase de acetolactato (SCESMY3008C02), desidrogenase de malato (SCESMY3001C06) e catalase (SCESMY3006H06).

O regulon 14 é composto por um único gene que codifica uma proteína putativa de arroz (SCESMY1001C08), o qual é fracamente induzido nas condições PANi e PBGc.

O regulon 15 é composto por quatro genes induzidos em raízes não-inoculadas independente do nível de P., os quais são similares a histona H3 (SCESMY3005B05), citocromo b5 (SCESMY3005H12) e duas proteínas hipotéticas (SCESMY3003F08 e SCESMY2003C09).

\subsubsection{Análise da expressão gênica por hibridização em macroarranjos de cDNA}

O RNA total que foi extraído das raízes de cana-de-açúcar colonizadas por G. clarum e dos respectivos controles não-inoculados foram utilizados para a síntese de sondas marcadas $c o m{ }^{33} \mathrm{P}$, as quais foram utilizadas nas hibridizações. Os sinais de hibridização foram normalizados 
utilizando-se os sinais obtidos com a sonda OverGo, o sinal total de hibridização das membranas e o sinal do controle constitutivo.

Após a normalização das membranas, foi feita a organização destes valores em planilhas do Microsoft Excel ${ }^{\circledR}$. As membranas hibridizadas com a mesma sonda foram agrupadas, tendo para cada gene 2 repetições por membrana e 3 repetições da membrana, totalizando6 "spots" analisados para cada gene.

Os tratamentos foram, então, organizados dois a dois para as comparações. A partir dos pontos analisados foram calculadas as variáveis A e M (Figura 7, 8, 9, 10 e 11).

Os genes com expressão diferencial foram divididos em categorias funcionais e são representados na figura 7. Nesta figura, também é mostrada a composição do arranjo de acordo com as categorias funcionais.

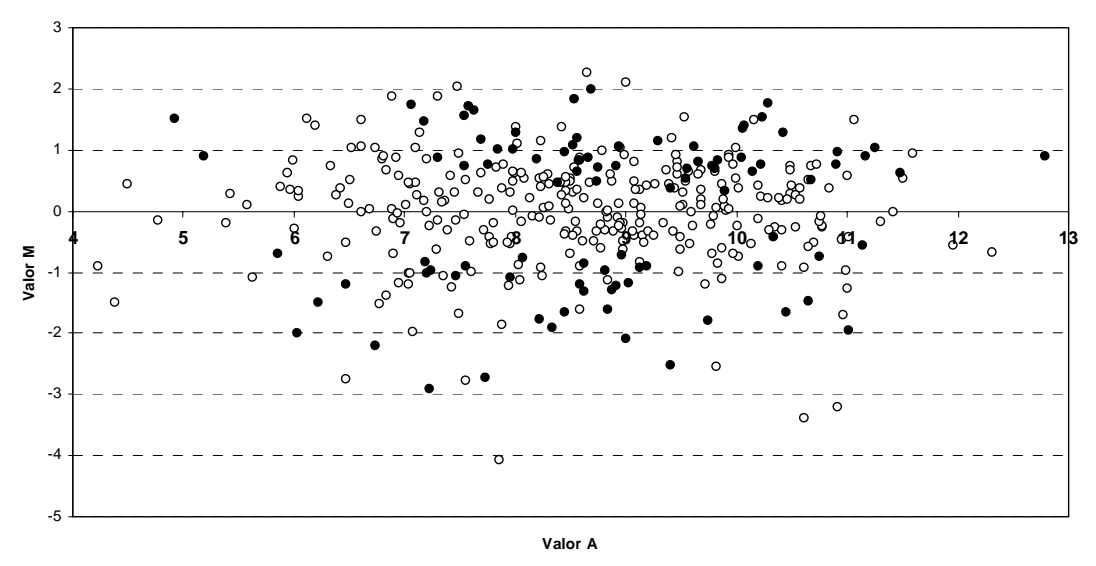

Figura 7 - Relação entre a variação das razões e intensidades de expressão entre raízes colonizadas por Glomus clarum e controles não-inoculados, cultivados em baixo P (PBGc/PBNi). Os valores $\mathrm{M}$ indicam $\log _{2}$ das razões de expressão e valores $\mathrm{A}$ indicam $\log _{2}$ da raiz quadrada do produto das médias dos tratamentos. •, genes com expressão diferencial significativa (test $\mathrm{t}, \mathrm{p}<0,05$ ) 


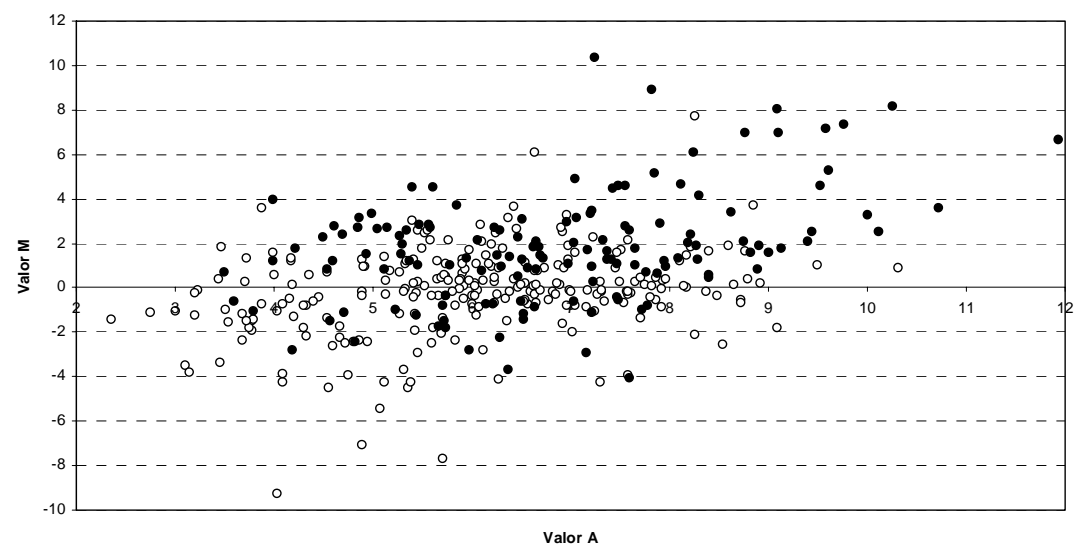

Figura 8 - Relação entre a variação das razões e intensidades de expressão entre raízes colonizadas por Glomus clarum e controles não-inoculados, cultivados em alto P (PAGc/PANi). Os valores $\mathrm{M}$ indicam $\log _{2}$ das razões de expressão e valores $\mathrm{A}$ indicam $\log _{2}$ da raiz quadrada do produto das médias dos tratamentos. •, genes com expressão diferencial significativa (test $\mathrm{t}, \mathrm{p}<0,05$ )

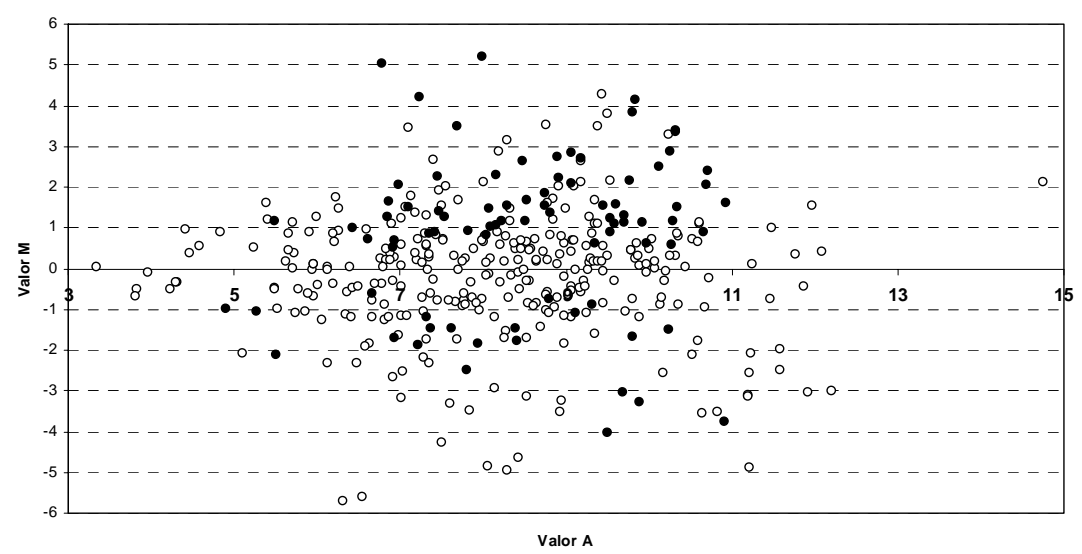

Figura 9 - Relação entre a variação das razões e intensidades de expressão entre raízes nãoinoculadas, cultivadas em alto $\mathrm{P}$ ou baixo $\mathrm{P}$ (PANi/PBNi). Os valores $\mathrm{M}$ indicam $\log _{2}$ das razões de expressão e valores A indicam $\log _{2}$ da raiz quadrada do produto das médias dos tratamentos. •, genes com expressão diferencial significativa (test t, $\mathrm{p}<0,05)$ 


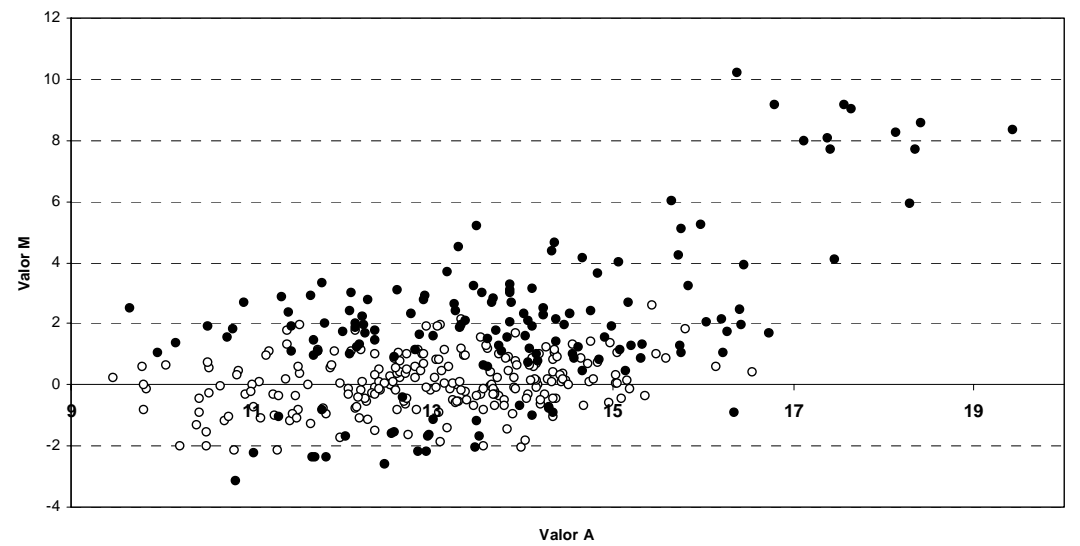

Figura 10 - Relação entre a variação das razões e intensidades de expressão entre raízes colonizadas, cultivadas em alto P ou baixo P (PAGc/PBGc). Os valores $\mathrm{M}$ indicam $\log _{2}$ das razões de expressão e valores A indicam $\log _{2}$ da raiz quadrada do produto das médias dos tratamentos •, genes com expressão diferencial significativa (test t, $\mathrm{p}<0,05)$

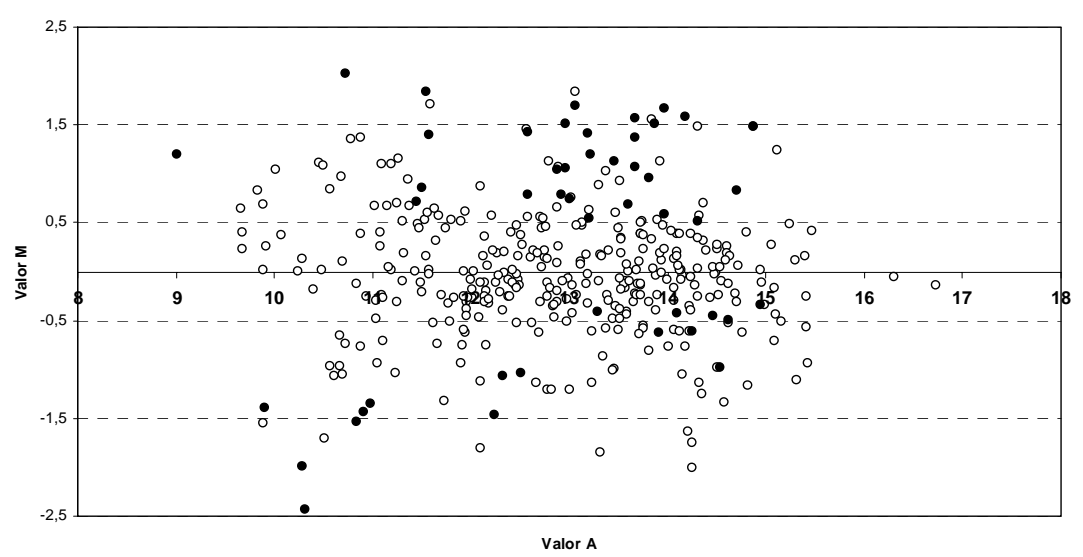

Figura 11 - Relação entre a variação das razões e intensidades de expressão entre raízes nãoinoculadas, cultivadas em alto $\mathrm{P}$ e raízes colonizadas cultivadas em baixo $\mathrm{P}$ (PANi/PBGc). Os valores $\mathrm{M}$ indicam $\log _{2}$ das razões de expressão e valores $\mathrm{A}$ indicam $\log _{2}$ da raiz quadrada do produto das médias dos tratamentos $\bullet$, genes com expressão diferencial significativa (test $\mathrm{t}, \mathrm{p}<0,05$ ) 
A identificação dos genes com expressão diferencial e sua anotação são mostrados nas tabelas 6, 7, 8, 9 e 10. Também é mostrado o valor M que expressa a razão de expressão do gene.

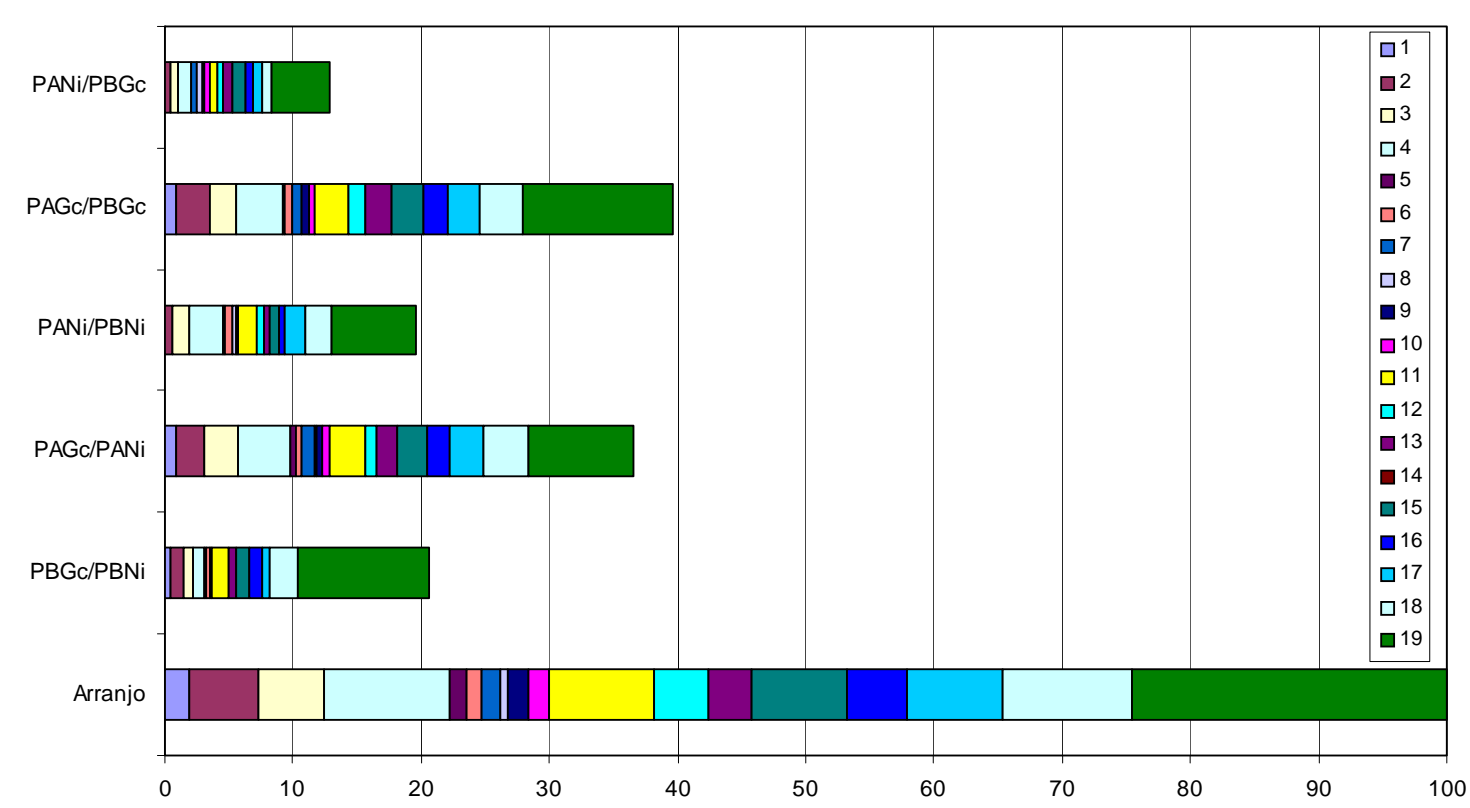

Figura 12 - Frequência de genes de diferentes categorias com expressão diferencial significativa $(\mathrm{p}<0,05)$ determinada por hibridização com macroarranjos de cDNAs, e dos genes utilizados para a confecção de macroarranjos de cDNAs. 
Tabela 5 - Genes com expressão diferencial em raízes colonizadas por Glomus clarum e cultivadas em 20 mg P kg-1 comparadas com raízes não-inoculadas e cultivadas em 20 mg P kg-1

(continua)

\begin{tabular}{|c|c|c|}
\hline Cluster & Blast & $\mathbf{M}$ \\
\hline $\begin{array}{l}\text { SCESMY4001H06 } \\
\end{array}$ & $\begin{array}{l}\text { transcriptional regulator, LysR family [Pseudomonas syringae pv. tomato str. } \\
\text { DC3000] }\end{array}$ & $\overline{-2,91}$ \\
\hline SCESMY2001A07 & putative senescence-associated protein [Pisum sativum] & $-2,71$ \\
\hline SCESMY2004A02 & hypothetical protein [Neurospora crassa] & $-2,52$ \\
\hline SCESMY3006A08 & pre-mRNA splicing factor SF2p33 & $-2,19$ \\
\hline SCESMY2005G02 & $\begin{array}{l}\text { dbj|BAA85422.1| (AP000616) similar to putative reverse transcriptase (AC005315) } \\
\text { [Oryza sativa] }\end{array}$ & $-2,07$ \\
\hline SCESMY1001C10 & cluster sem notação & $-2,00$ \\
\hline SCESMS1008F10 & metallothionein $2 \mathrm{~b}$ & $-1,94$ \\
\hline SCESMY3005G03 & eIF-4a eIF-4a gene product & $-1,91$ \\
\hline SCESMY1003G12 & $\begin{array}{l}\text { COG0436: Aspartate/tyrosine/aromatic aminotransferase [Pseudomonas fluorescens } \\
\text { PfO-1] }\end{array}$ & $-1,80$ \\
\hline SCESMY4001H07 & conserved hypothetical protein [Pseudomonas syringae pv. tomato str. DC3000] & $-1,76$ \\
\hline SCESMY2008B07 & unknown protein [Oryza sativa (japonica cultivar-group)] & $-1,65$ \\
\hline SCESMS1002D02 & Ac1147 [Rattus norvegicus] & $-1,64$ \\
\hline SCESMY2005D05 & metallothionein $2 \mathrm{~b}$ & $-1,61$ \\
\hline SCESMY2008B11 & $\begin{array}{l}\text { emb|CAC27017.1| (AJ010592) ubiquitin-conjugating enzyme E2-21 KD [Guillardia } \\
\text { theta] }\end{array}$ & $-1,50$ \\
\hline SCESMY3001E03 & putative alpha-L-arabinofuranosidase [Arabidopsis thaliana] & $-1,47$ \\
\hline SCESMY3005C07 & cyclophylin -like protein & $-1,31$ \\
\hline SCESMY3003F01 & AIG1-like protein & $-1,28$ \\
\hline SCESMY2004H11 & cytosolic ascorbate peroxidase [Zea mays] & $-1,21$ \\
\hline SCESMY1001E01 & protein kinase -like protein & $-1,19$ \\
\hline SCESMY1001B11 & $\begin{array}{l}\text { COG0477: Permeases of the major facilitator superfamily [Pseudomonas fluorescens } \\
\text { PfO-1] }\end{array}$ & $-1,19$ \\
\hline SCESMY3004E05 & S-adenosylmethionine synthase 2 & $-1,18$ \\
\hline SCESMY2001C02 & methionine synthase protein [Sorghum bicolor] & $-1,07$ \\
\hline SCESMY2001A06 & elongation factor 1-alpha [Zea mays] & $-1,06$ \\
\hline SCESMY2003F04 & $\begin{array}{l}\text { dbj|BAB08667.1| (AB018109) gene_id:K17N15.6 unknown protein [Arabidopsis } \\
\text { thaliana] }\end{array}$ & $-1,01$ \\
\hline SCESMY2008C05 & Cluster sem notação & $-0,98$ \\
\hline SCESMY2005F03 & Cluster sem notação & $-0,96$ \\
\hline SCESMY2003G02 & $\begin{array}{l}\text { dbj|BAB08247.1| (AB006698) gene_id:MCL19.6 unknown protein [Arabidopsis } \\
\text { thaliana] }\end{array}$ & $-0,92$ \\
\hline SCESMY3008H09 & EXIT & $-0,90$ \\
\hline SCESMY4003B05 & unknown protein [Arabidopsis thaliana] & $-0,89$ \\
\hline SCESMY3005A09 & putative protein & $-0,89$ \\
\hline SCESMY2004F05 & germin-like protein (GLP10) & $-0,85$ \\
\hline SCESMY2001A12 & metallothionein-like protein type 3 [Hordeum vulgare subsp. vulgare] & $-0,83$ \\
\hline SCESMY2008A11 & metallothionein $2 \mathrm{~b}$ & $-0,77$ \\
\hline SCESMS1001A02 & hypotetical protein [Oryza sativa (japonica cultivar-group)] & $-0,74$ \\
\hline SCESMY2008B12 & pir||S53126 dnaK-type molecular chaperone hsp70 - rice (fragment) & $-0,71$ \\
\hline
\end{tabular}


Tabela 5 - Genes com expressão diferencial em raízes colonizadas por Glomus clarum e cultivadas em 20 mg P kg-1 comparadas com raízes não-inoculadas e cultivadas em 20 mg P kg-1

\begin{tabular}{|c|c|c|}
\hline \multicolumn{3}{|c|}{ (continuação) } \\
\hline Cluster & Blast & $\mathbf{M}$ \\
\hline SCESMY2003H09 & Cluster sem notação & \\
\hline SCESMY3005H12 & putative cytochrome b5 & \\
\hline SCESMY3008B10 & $\begin{array}{l}\text { dbj|BAB08448.1| (AB017067) contains similarity to glutathione-S- } \\
\text { transferase/glutaredoxin gene_id:MJC20.26 [Arabidopsis }\end{array}$ & \\
\hline SCESMY2008A09 & $\begin{array}{l}\text { pir||T47701 translation initiation factor eIF-6-like protein [imported] - Arabidopsis } \\
\text { thaliana }\end{array}$ & 0,32 \\
\hline SCESMY2005E11 & 40S ribosomal protein S9 [Arabidopsis thaliana] & \\
\hline SCESMY2001G11 & OSJNBa0041M06.4 [Oryza sativa (japonica cultivar-group)] & \\
\hline SCESMY2003D04 & sp|Q10716|CYS1_MAIZE CYSTEINE PROTEINASE 1 PRECURSOR & \\
\hline SCESMY2008A10 & emb|CAC21392.1| (AJ401275) peroxidase [Zea mays] & \\
\hline SCESMY2005D02 & sp|Q42456|APR1_ORYSA ASPARTIC PROTEINASE ORYZASIN 1 PRECURSOR & \\
\hline SCESMY3001G02 & DHAB_ORYSA BETAINE-ALDEHYDE DEHYDROGENASE (BADH) & \\
\hline SCESMY2009E05 & $\begin{array}{l}\text { H+-transporting ATPase (EC 3.6.1.35) - maize ; H+-transporting ATPase (EC } \\
\text { 3.6.1.35) - maize ; H+-transporting ATPase type 2, plasma membrane (a.thaliana) } \\
948 \text { aa }\end{array}$ & \\
\hline SCESMY2008A04 & sp|Q05761|RS13_MAIZE 40S RIBOSOMAL PROTEIN S13 & \\
\hline SCESMY1002D06 & hypothetical protein [Oryza sativa (japonica cultivar-group)] & \\
\hline SCESMY2004C08 & heat shock protein $70 \mathrm{kDa}$ [Zea mays] & \\
\hline SCESMY2004H06 & putative $\mathrm{Ca} 2+$ dependent protein kinase & \\
\hline SCESMY3001C06 & $\begin{array}{l}\text { probable malate dehydrogenase (oxaloacetate-decarboxylating) (NADP+) (EC } \\
\text { 1.1.1.40) - maize }\end{array}$ & \\
\hline SCESMY2008H12 & $\begin{array}{l}\text { sp|P40280|H2A_MAIZE HISTONE H2A >gi|7439704|pir||T02076 histone H2A - } \\
\text { maize }\end{array}$ & \\
\hline SCESMY2001B06 & putative ubiquitin-specific protease otubain 1 [Oryza sativa (japonica cultivar-group)] & \\
\hline SCESMY2009G10 & hypothetical protein YUP8H12R.26 - Arabidopsis thaliana ; & \\
\hline SCESMY2008A06 & $\begin{array}{l}\text { emb|CAA13175.1| (AJ231133) caffeic acid 3-O-Methyltransferase [Saccharum } \\
\text { officinarum] }\end{array}$ & \\
\hline SCESMY3003C12 & 60 S ribosomal protein L39 & \\
\hline SCESMY2008A08 & similar to putative regulatory protein AtsB of Klebsiella pneumoniae & \\
\hline SCESMY2003D01 & putative U5 small nuclear ribonucleoprotein, an RNA helicase & \\
\hline SCESMY4003C05 & hypothetical protein b1956 [Escherichia coli K12] & \\
\hline SCESMY2004E12 & ubiquitin-protein ligase UBC9 & \\
\hline SCESMY1002F04 & L-carnitine dehydrogenase-like protein [Acinetobacter sp. NCIMB9871] & \\
\hline SCESMY4001B05 & succinyl-CoA synthetase, alpha chain [Bordetella pertussis Tohama I] & \\
\hline SCESMY2003B10 & Glutathione transferase III(b) [Zea mays]; Glutathione transferase III-like protein & \\
\hline SCESMY2001H04 & elongation factor 1 gamma-like protein [Oryza sativa (japonica cultivar-group)] & \\
\hline SCESMY4001C04 & similar to unknown protein [Arabidopsis thaliana] & \\
\hline SCESMS1002C04 & caffeoyl-CoA O-methyltransferase - like protein & \\
\hline SCESMY1003A10 & $\begin{array}{l}\text { COG4213: ABC-type xylose transport system, periplasmic component [Pseudomonas } \\
\text { fluorescens PfO-1] }\end{array}$ & \\
\hline SCESMY1002D01 & $\begin{array}{l}\text { COG0477: Permeases of the major facilitator superfamily [Burkholderia cepacia } \\
\text { R18194] }\end{array}$ & \\
\hline SCESMY2001F10 & 40S ribosomal protein S16 & \\
\hline
\end{tabular}


Tabela 5 - Genes com expressão diferencial em raízes colonizadas por Glomus clarum e cultivadas em 20 mg P kg-1 comparadas com raízes não-inoculadas e cultivadas em 20 mg P kg-1

(conclusão)

\begin{tabular}{llr}
\hline Cluster & Blast & M \\
\hline SCESMY4003A04 & tetratricopeptide repeat(TPR)-containing protein-like [Oryza sativa & 1,03 \\
SCESMY4002B05 & Anaerobic dehydrogenases, typically selenocysteine-containing [Pseudomonas & 1,03 \\
& fluorescens PfO-1] & 1,06 \\
SCESMY2004F01 & $\begin{array}{l}\text { putative nitrilase-associated protein Alternative splicing exists based on EST } \\
\text { evidence }\end{array}$ & 1,07 \\
SCESMY2003B05 & probable germin protein 4 - rice ; germin-like protein (GLP10) & 1,09 \\
SCESMY2003B09 & Cluster sem anotação & 1,15 \\
SCESMY3006B02 & unknown protein [Arabidopsis thaliana] & 1,17 \\
SCESMY3004F06 & putative extensin & 1,21 \\
SCESMY2004C11 & Cluster sem notação & 1,28 \\
SCESMY2001D11 & cinnamoyl-CoA reductase - like protein & 1,30 \\
SCESMY2001C09 & (AP002855) hypothetical protein [Oryza sativa] & 1,36 \\
SCESMY3002F12 & aldehyde oxidase & 1,40 \\
SCESMY2008H05 & Sp|P38385|S61G_ORYSA PROTEIN TRANSPORT PROTEIN SEC61 GAMMA & 1,47 \\
& SUBUNIT & 1,52 \\
SCESMY4003A05 & polynucleotide adenylyltransferase homolog T16I18.60 - Arabidopsis thaliana \\
SCESMY4001C06 & diaminobutyrate--pyruvate aminotransferase [Bordetella parapertussis 12822] & 1,54 \\
SCESMY2005F06 & AP2 domain containing protein RAP2.3 [Arabidopsis thaliana] & 1,57 \\
SCESMY3008H05 & Cluster sem notação & 1,66 \\
SCESMY1002G04 & pir||T47879 hypothetical protein T4C21.90 - Arabidopsis thaliana & \\
& >gi|7329678|emb|CAB82672.1| (AL162295) putative protei & 1,73 \\
SCESMY1002B09 & COG0155: Sulfite reductase, beta subunit (hemoprotein) [Pseudomonas syringae pv. & \\
& syringae B728a] & 1,75 \\
SCESMY4002E07 & elongation factor EF-2 [Arabidopsis thaliana] & 1,76 \\
SCESMY2009F07 & Membrane carboxypeptidase (penicillin-binding protein) [Pseudomonas fluorescens & \\
& PfO-1] & 1,83 \\
SCESMY2001B01 & P0692C11.18 [Oryza sativa (japonica cultivar-group)] & 2,01 \\
SCESMY3003B06 & Cluster sem notação \\
\hline & & \\
& &
\end{tabular}


Tabela 6 - Genes com expressão diferencial em raízes colonizadas por Glomus clarum e cultivadas em $200 \mathrm{mg} \mathrm{P} \mathrm{kg}^{-1}$ comparadas com raízes não-inoculadas cultivadas em 200 mg P kg-1

\begin{tabular}{|c|c|c|}
\hline Cluster & Blast & $\mathbf{M}$ \\
\hline 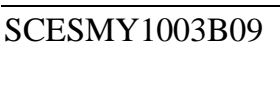 & $\begin{array}{l}\text { MAL5, MUC1 glucoamylase s1/s2 precursor (glucan 1,4-alpha-glucosidase) (1,4- } \\
\text { alpha-D-glucan glucohydrolase) }\end{array}$ & $-4,04$ \\
\hline SCESMY2003A09 & $\begin{array}{l}\text { contains ESTs AU097436(S4951),D41930(S4951),AU101944(S2163), } \\
\text { AU095016(E50186),AU058216(E5018 }\end{array}$ & $-3,67$ \\
\hline SCESMY3008B10 & $\begin{array}{l}\text { dbj|BAB08448.1| (AB017067) contains similarity to glutathione-S- } \\
\text { transferase/glutaredoxin gene_id:MJC20.26 [Arabidopsis }\end{array}$ & $-2,94$ \\
\hline SCESMY2008H12 & $\begin{array}{l}\text { sp|P40280|H2A_MAIZE HISTONE H2A >gi|7439704|pir||T02076 histone H2A - } \\
\text { maize }\end{array}$ & $-2,79$ \\
\hline SCESMY4002B04 & putative pyrophosphate-dependent phosphofructo-1-kinase [Oryza sativa] & $-2,76$ \\
\hline SCESMY3004E05 & S-adenosylmethionine synthase 2 & $-2,41$ \\
\hline SCESMY2003C09 & $\begin{array}{l}\text { hypothetical protein [Arabidopsis thaliana] ; MAL5, MUC1 glucoamylase s1/s2 } \\
\text { precursor (glucan 1,4-alpha-glucosidase) (1,4- alpha-D-glucan glucohydrolase) } \\
\text { [EC:3.2.1.3] }\end{array}$ & $-2,24$ \\
\hline SCESMY2001C02 & methionine synthase protein [Sorghum bicolor] & $-1,80$ \\
\hline SCESMY2001F03 & COG0598: Mg2+ and Co2+ transporters [Pseudomonas fluorescens PfO-1] & $-1,75$ \\
\hline SCESMY2008F12 & pir||T04664 hypothetical protein F8D20.100 - Arabidopsis thaliana & $-1,50$ \\
\hline SCESMY3003H02 & dnaJ protein homolog atj3 & $-1,45$ \\
\hline SCESMY3002D07 & $\mathrm{H}^{+}$-transporting ATPase $16 \mathrm{~K}$ chain $\mathrm{P} 2$, vacuolar & $-1,41$ \\
\hline SCESMY2005C06 & FRAAN 40S RIBOSOMAL PROTEIN S23 (S12) & $-1,25$ \\
\hline SCESMY1002C07 & putative phosphohydrolase [Bordetella parapertussis 12822] & $-1,17$ \\
\hline SCESMY2004F01 & putative nitrilase-associated protein Alternative splicing exists based on EST evidence & $-1,13$ \\
\hline SCESMY4001B07 & mitogen-activated protein kinase MMK: & $-1,09$ \\
\hline SCESMY2008F11 & pir||T04331 golgi associated protein se-wap41 - maize & $-1,03$ \\
\hline SCESMY3008D05 & homeotic $\mathrm{F}$ & $-0,98$ \\
\hline SCESMY2003E01 & $\begin{array}{l}22 \mathrm{kDa} \text { drought-inducible protein [Saccharum hybrid cultivar] dbj|BAB68268.1| } \\
\text { drought inducible } 22 \mathrm{kD} \text { protein [Saccharum officinarum] }\end{array}$ & $-0,97$ \\
\hline SCESMY3006D12 & Cluster sem notação & $-0,82$ \\
\hline SCESMY3005A09 & putative protein & $-0,81$ \\
\hline SCESMY2008F07 & $\begin{array}{l}\text { sp|P12857|ADT2_MAIZE ADP,ATP CARRIER PROTEIN } 2 \text { PRECURSOR } \\
\text { (ADP/ATP TRANSLOCASE 2) (ADENINE NUCLEOTIDE TRANSLOCATOR 2) }\end{array}$ & $-0,77$ \\
\hline SCESMY2005D02 & sp|Q42456|APR1_ORYSA ASPARTIC PROTEINASE ORYZASIN 1 PRECURSOR & $-0,73$ \\
\hline SCESMY2005A03 & cytoch & $-0,71$ \\
\hline SCESMY2001A01 & cluster sem notação & $-0,60$ \\
\hline SCESMY2001E03 & putative cytochrome $\mathrm{P}$ & $-0,59$ \\
\hline SCESMY1002D10 & Putative regulatory protein [Bordetella bronchiseptica RB50] & $-0,59$ \\
\hline SCESMY2008A07 & cytochrome C oxidase subunit III [Leifsonia xyli subsp. xyli str. CTCB07] & $-0,51$ \\
\hline SCESMY2005E01 & $\begin{array}{l}\text { conserved hypothetical protein [Salmonella enterica subsp. enterica serovar Typhi str. } \\
\text { CT18] }\end{array}$ & $-0,41$ \\
\hline SCESMY2004H11 & cytosolic ascorbate peroxidase [Zea mays] & $-0,35$ \\
\hline SCESMY2001F05 & COG0438: Glycosyltransferase [Pseudomonas syringae pv. syringae B728a] & 0,28 \\
\hline
\end{tabular}


Tabela 6 - Genes com expressão diferencial em raízes colonizadas por Glomus clarum e cultivadas em $200 \mathrm{mg} \mathrm{P} \mathrm{kg}^{-1}$ comparadas com raízes não-inoculadas cultivadas em $200 \mathrm{mg} \mathrm{P} \mathrm{kg}^{-1}$

(continuação)

\begin{tabular}{|c|c|c|}
\hline Cluster & Blast & $\mathbf{M}$ \\
\hline SCESMY2005G03 & $\begin{array}{l}\text { gb|AAB95279.1| (AF002109) unknown protein [Arabidopsis thaliana] }\end{array}$ & 0,47 \\
\hline SCESMY2001F04 & alpha-tubulin [Miscanthus floridulus] & 0,54 \\
\hline SCESMY1003B03 & isovaleryl-CoA dehydrogenase [Bordetella bronchiseptica RB50] & 0,62 \\
\hline SCESMY2009D10 & probable tonoplast aquaporin - maize & 0,66 \\
\hline SCESMY2004G01 & putative WD-40 repeat - protein & 0,72 \\
\hline SCESMY4002G02 & $\begin{array}{l}\text { TPIC_SECCE TRIOSEPHOSPHATE ISOMERASE, CHLOROPLAST } \\
\text { PRECURSOR (TIM) }\end{array}$ & 0,73 \\
\hline SCESMY2004G07 & putative receptor-like protein kinase & 0,78 \\
\hline SCESMY2001F10 & 40S ribosomal protein S16 & 0,81 \\
\hline SCESMY1002H06 & Phyb1 [Pimpinella brachycarpa] & 0,82 \\
\hline SCESMY1003H07 & $\begin{array}{l}\text { COG0745: Response regulators consisting of a CheY-like receiver domain and a } \\
\text { winged-helix DNA-binding domain [Pseudomonas fluorescens PfO-1] }\end{array}$ & 0,84 \\
\hline SCESMY2005B08 & RNA binding protein Rp120 [Oryza sativa (japonica cultivar-group)] & 0,86 \\
\hline SCESMY1001G03 & EXIT & 0,88 \\
\hline SCESMY2005C07 & syntaxin homologue & 0,94 \\
\hline SCESMY4003B02 & hypothetical protein [Arabidopsis thaliana] & 0,94 \\
\hline SCESMY3004C11 & putative citrate synthase & 0,97 \\
\hline SCESMY3008F12 & profilin 5 [Zea mays] & 1,00 \\
\hline SCESMY1001C06 & adenosylhomocysteinase & 1,03 \\
\hline SCESMY4003A04 & tetratricopeptide repeat(TPR)-containing protein-like [Oryza sativa & 1,05 \\
\hline SCESMY3003C12 & 60 S ribosomal protein L39 & 1,07 \\
\hline SCESMY2003C08 & MT1_ORYSA METALLOTHIONEIN-LIKE PROTEIN TYPE 1 ; metallothionein 2b & 1,12 \\
\hline SCESMY3001E05 & glycine-rich RNA-binding protein [Sorghum bicolor] & 1,21 \\
\hline SCESMY3006B02 & unknown protein [Arabidopsis thaliana] & 1,22 \\
\hline SCESMY1003E06 & translation initiation factor 4D (Homo sapiens) & 1,24 \\
\hline SCESMY4002F02 & similar to unknown protein [Arabidopsis thaliana] & 1,24 \\
\hline SCESMY2001C06 & putative tryptophan synthase alpha chain [Oryza sativa (japonica cultivar-group)] & 1,26 \\
\hline SCESMY2008E04 & pir||T49120 serine/threonine protein kinase like protein & 1,27 \\
\hline SCESMY2008D09 & Cluster sem notação & 1,27 \\
\hline SCESMY2004C01 & polyubiquitin [Sporobolus stapfianus] & 1,27 \\
\hline SCESMY4001G05 & $\begin{array}{l}\text { D-isomer specific 2-hydroxyacid dehydrogenase family protein [Pseudomonas putida } \\
\text { KT2440] }\end{array}$ & 1,33 \\
\hline SCESMY2003G10 & $\begin{array}{l}\text { ABC transporter, substrate binding protein [oligopeptide] [Agrobacterium tumefaciens } \\
\text { str. C58] }\end{array}$ & 1,34 \\
\hline SCESMY2001D01 & hypothetical protein [Oryza sativa (japonica cultivar-group)... & 1,34 \\
\hline SCESMY3002C10 & MADS box protein 1 [Zea mays] & 1,39 \\
\hline SCESMY2001B08 & serine/threonine kinase-like protein & 1,44 \\
\hline SCESMY1001H05 & collagen, type I, alpha 2 (Homo sapiens) & 1,50 \\
\hline SCESMY2004F12 & ABC transporter homolog PnATH - like & 1,51 \\
\hline SCESMY2001G12 & type 1 rice metallothionein-like gene; & 1,55 \\
\hline SCESMY1003D10 & mucin 2, intestinal (GB:L21998) (Homo sapiens) & 1,60 \\
\hline SCESMS1002D02 & Ac1147 [Rattus norvegicus] & 1,61 \\
\hline
\end{tabular}


Tabela 6 - Genes com expressão diferencial em raízes colonizadas por Glomus clarum e cultivadas em $200 \mathrm{mg} \mathrm{P} \mathrm{kg}^{-1}$ comparadas com raízes não-inoculadas cultivadas em 200 mg P kg-1

(continuação)

\begin{tabular}{|c|c|c|}
\hline Cluster & Blast & $\mathbf{M}$ \\
\hline SCESMY2008F10 & sp|P14641|TBA2_MAIZE TUBULIN ALPHA-2 CHAIN & 1,67 \\
\hline SCESMY3008F09 & putative oligopeptide transport ATP-binding protein [Bordetella bronchiseptica RB50] & 1,72 \\
\hline SCESMY2009H08 & Cluster sem anotação & 1,76 \\
\hline SCESMY2003F12 & $\begin{array}{l}\text { sp|P54774|CC48_SOYBN CELL DIVISION CYCLE PROTEIN } 48 \text { HOMOLOG } \\
\text { (VALOSIN CONTAINING PROTEIN HOMOLOG) (VCP) }\end{array}$ & 1,76 \\
\hline SCESMY4002A09 & hypothetical protein F27K19.140 - Arabidopsis thaliana & 1,80 \\
\hline SCESMY1003E08 & gamma-glutamylcysteine synthetase & 1,82 \\
\hline SCESMY3007F07 & calmodulin 1 (CAM1) & 1,87 \\
\hline SCESMY3004A06 & AF140722) pathogenesis-related protein [Oryza sativa] & 1,88 \\
\hline SCESMY3005H12 & putative cytochrome b5 & 1,93 \\
\hline SCESMY1001D08 & COG0583: Transcriptional regulator [Pseudomonas fluorescens PfO-1] & 1,93 \\
\hline SCESMY2001A07 & putative senescence-associated protein [Pisum sativum] & 1,99 \\
\hline SCESMY2003D01 & putative U5 small nuclear ribonucleoprotein, an RNA helicase & 2,05 \\
\hline SCESMY2009F07 & $\begin{array}{l}\text { Membrane carboxypeptidase (penicillin-binding protein) [Pseudomonas fluorescens } \\
\text { PfO-1] }\end{array}$ & 2,06 \\
\hline SCESMY1003F05 & MtN3-like protein & 2,08 \\
\hline SCESMY1002D01 & $\begin{array}{l}\text { COG0477: Permeases of the major facilitator superfamily [Burkholderia cepacia } \\
\text { R18194] }\end{array}$ & 2,10 \\
\hline SCESMY1003F01 & $\begin{array}{l}\text { COG2133: Glucose/sorbosone dehydrogenases [Pseudomonas syringae pv. syringae } \\
\text { B728a] }\end{array}$ & 2,11 \\
\hline SCESMY2005D05 & metallothionein $2 \mathrm{~b}$ & 2,17 \\
\hline SCESMY1003H11 & AP2 domain transcription factor (ABI4:abscisic acid-insensitive 4 ) & 2,17 \\
\hline SCESMY3007C12 & vacuolar $\mathrm{H}(+)$-ATPase subunit-like protein & 2,29 \\
\hline SCESMY1001D01 & COG0607: Rhodanese-related sulfurtransferase [Azotobacter vinelandii] & 2,29 \\
\hline SCESMY4001D03 & Outer membrane receptor proteins, mostly Fe transport [Pseudomonas aeruginosa & 2,34 \\
\hline SCESMY4003G04 & ligand-gated channel-like protein precursor [imported] - Arabidopsis thaliana & 2,38 \\
\hline SCESMY2009B08 & protein kinase-like [Arabidopsis thaliana] & 2,44 \\
\hline SCESMS1002F07 & elongation factor 1-alpha [Zea mays] & 2,55 \\
\hline SCESMS1001A02 & hypotetical protein [Oryza sativa (japonica cultivar-group)] & 2,55 \\
\hline SCESMY4001A04 & TBA1_ELEIN TUBULIN ALPHA-1 CHAIN (ALPHA-TUBULIN 1) & 2,61 \\
\hline SCESMY4001B01 & Acyl-CoA dehydrogenases [Pseudomonas fluorescens PfO-1] & 2,61 \\
\hline SCESMY2001B06 & putative ubiquitin-specific protease otubain 1 [Oryza sativa (japonica cultivar-group)] & 2,63 \\
\hline SCESMY1001G07 & $\begin{array}{l}\text { COG1020: Non-ribosomal peptide synthetase modules and related proteins } \\
\text { [Pseudomonas fluorescens PfO-1] }\end{array}$ & 2,69 \\
\hline SCESMY2004E08 & GcpE protein [Arabidopsis thaliana] & 2,69 \\
\hline SCESMY2003H01 & $\begin{array}{l}\text { dbj|BAB09871.1| (AB008268) emb|CAB89373.1 gene_id:MSJ1.24 similar to } \\
\text { unknown protein [Arabidopsis thaliana] }\end{array}$ & 2,72 \\
\hline SCESMY4003C02 & scarecrow-like 1 [Arabidopsis thaliana] & 2,73 \\
\hline SCESMY4001C06 & diaminobutyrate--pyruvate aminotransferase [Bordetella parapertussis 12822] & 2,74 \\
\hline SCESMY1001E01 & protein kinase -like protein & 2,80 \\
\hline SCESMY4001A07 & similar to unknown protein [Arabidopsis thaliana] & 2,80 \\
\hline SCESMY4003A05 & polynucleotide adenylyltransferase homolog T16I18.60 - Arabidopsis thaliana & 2,84 \\
\hline
\end{tabular}


Tabela 6 - Genes com expressão diferencial em raízes colonizadas por Glomus clarum e cultivadas em $200 \mathrm{mg} \mathrm{P} \mathrm{kg}^{-1}$ comparadas com raízes não-inoculadas cultivadas em 200 mg P kg-1

(conclusão)

\begin{tabular}{|c|c|c|}
\hline Cluster & Blast & $\mathbf{M}$ \\
\hline$\overline{\text { SCESMY1001H02 }}$ & $\begin{array}{l}\text { COG1879: ABC-type sugar transport system, periplasmic component [Azotobacter } \\
\text { vinelandii] }\end{array}$ & 2,87 \\
\hline SCESMY4001G03 & Osmosensitive $\mathrm{K}+$ channel histidine kinase [Pseudomonas fluorescens PfO-1] & 2,93 \\
\hline SCESMY4003E02 & F21B7.1 [Arabidopsis thaliana] & 2,95 \\
\hline SCESMY1001F02 & unknown protein & 3,12 \\
\hline SCESMY2004F08 & hypothetical protein [Oryza sativa] & 3,15 \\
\hline SCESMY2001C04 & $\begin{array}{l}\text { COG1020: Non-ribosomal peptide synthetase modules and related proteins } \\
\text { [Pseudomonas fluorescens PfO-1] }\end{array}$ & 3,15 \\
\hline SCESMY2004A02 & hypothetical protein [Neurospora crassa] & 3,27 \\
\hline SCESMY1003F08 & $\begin{array}{l}\text { Similarity to Yeast uridine kinase (SP:URK1_YEAST) [EC:2.7.1.48] (c.elegans) } 515 \\
\text { aa }\end{array}$ & 3,32 \\
\hline SCESMY1002G09 & 14-3-3-LIKE PROTEIN GF14 UPSILON & 3,37 \\
\hline SCESMY4001H07 & conserved hypothetical protein [Pseudomonas syringae pv. tomato str. DC3000] & 3,40 \\
\hline SCESMY4002E05 & Signal transduction histidine kinase [Pseudomonas fluorescens PfO-1] & 3,47 \\
\hline SCESMS1008A04 & proprotein convertase aPC6C isoform & 3,60 \\
\hline SCESMY1002B01 & $\begin{array}{l}\text { COG1020: Non-ribosomal peptide synthetase modules and related proteins } \\
\text { [Pseudomonas fluorescens PfO-1] }\end{array}$ & 3,75 \\
\hline SCESMY3005F09 & putative poly(A) polymerase & 3,98 \\
\hline SCESMY2004F09 & $\begin{array}{l}\text { L-alanine-DL-glutamate epimerase and related enzymes of enolase superfamily } \\
\text { [Pseudomonas fluorescens PfO-1] }\end{array}$ & 4,14 \\
\hline SCESMY1001D11 & putative protein & 4,46 \\
\hline SCESMY1003F09 & thioredoxin $\mathrm{h}$ & 4,53 \\
\hline SCESMY4003G03 & Permeases of the major facilitator superfamily [Pseudomonas fluorescens PfO-1] & 4,54 \\
\hline SCESMY4001H06 & transcriptional regulator, LysR family [Pseudomonas syringae pv. tomato str. DC3000] & 4,59 \\
\hline SCESMY3006A08 & pre-mRNA splicing factor SF2p33 & 4,60 \\
\hline SCESMY3003F01 & AIG1-like protein & 4,62 \\
\hline SCESMY1003C02 & phosphate ABC transporter, permease protein [Pseudomonas putida KT2440] & 4,69 \\
\hline SCESMY1001A11 & COG2831: Hemolysin activation/secretion protein [Pseudomonas fluorescens PfO-1] & 4,92 \\
\hline SCESMY3004D03 & unknown protein [Arabidopsis thaliana] & 5,18 \\
\hline SCESMY2005G02 & $\begin{array}{l}\text { dbj|BAA85422.1| (AP000616) similar to putative reverse transcriptase (AC005315) } \\
\text { [Oryza sativa] }\end{array}$ & 5,28 \\
\hline SCESMY3006H06 & catalase & 6,13 \\
\hline SCESMS1008F10 & metallothionein $2 \mathrm{~b}$ & 6,64 \\
\hline SCESMY2004G03 & putative beta-1,3-glucanase & 6,99 \\
\hline SCESMY2004H06 & putative $\mathrm{Ca} 2+$ dependent protein kinase & 6,99 \\
\hline SCESMY2004B03 & MT-like protein [Cynodon dactylon] & 7,18 \\
\hline SCESMY2005H03 & gb|AAF86550.1|AC069252_9 (AC069252) F2E2.14 [Arabidopsis thaliana] & 7,34 \\
\hline SCESMY3005B05 & histon $\mathrm{H} 3$ protein & 8,04 \\
\hline SCESMY2001H02 & hypothetical protein FG04948.1 [Gibberella zeae PH-1] & 8,16 \\
\hline SCESMY4003C05 & hypothetical protein b1956 [Escherichia coli K12] & 8,92 \\
\hline SCESMY1001H11 & polyubiquitin (ubq10) & 10,37 \\
\hline
\end{tabular}


Tabela 7 - Genes com expressão diferencial em raízes não-inoculadas e cultivadas em 200 mg P $\mathrm{kg}^{-1}$ comparadas com raizes não-inoculadas e cultivadas em $20 \mathrm{mg} \mathrm{P} \mathrm{kg}$.

\begin{tabular}{|c|c|c|}
\hline Cluster & Blast & $\mathbf{M}$ \\
\hline SCESMY2001A03 & (AC000104) F19P19.16 [Arabidopsis thaliana] & $-4,01$ \\
\hline SCESMY2008B06 & OSJNBb0032K15.17 [Oryza sativa (japonica cultivar-group)] & $-3,74$ \\
\hline SCESMY1003A10 & $\begin{array}{l}\text { COG4213: ABC-type xylose transport system, periplasmic component [Pseudomonas } \\
\text { fluorescens PfO-1] }\end{array}$ & $-3,27$ \\
\hline SCESMY2009G10 & hypothetical protein YUP8H12R.26 - Arabidopsis thaliana ; & $-3,03$ \\
\hline SCESMY2003A05 & glycine-rich protein & $-2,49$ \\
\hline SCESMY1001H02 & $\begin{array}{l}\text { COG1879: ABC-type sugar transport system, periplasmic component [Azotobacter } \\
\text { vinelandii] }\end{array}$ & $-2,09$ \\
\hline SCESMY2005D04 & WD-repeat protein RBAP1 [Zea mays] & $-1,86$ \\
\hline SCESMY2004D05 & enolase (2-phospho-D-glycerate hydroylase) & $-1,82$ \\
\hline SCESMY3004E05 & S-adenosylmethionine synthase 2 & $-1,75$ \\
\hline SCESMY2003E12 & Cluster sem notação & $-1,69$ \\
\hline SCESMY3005H12 & putative cytochrome b5 & $-1,67$ \\
\hline SCESMS1002D02 & Ac1147 [Rattus norvegicus] & $-1,48$ \\
\hline SCESMY2009G03 & $\begin{array}{l}\text { nodulin protein-like [Arabidopsis thaliana] ; putative integral membrane protein } \\
\text { nodulin }\end{array}$ & $-1,47$ \\
\hline SCESMY3003C03 & anthranilate phosphoribosyltransferase-like protein & $-1,46$ \\
\hline SCESMY2001C06 & putative tryptophan synthase alpha chain [Oryza sativa (japonica cultivar-group)] & $-1,45$ \\
\hline SCESMY2003D04 & sp|Q10716|CYS1_MAIZE CYSTEINE PROTEINASE 1 PRECURSOR & $-1,19$ \\
\hline SCESMY1003F05 & MtN3-like protein & $-1,09$ \\
\hline SCESMY3005F09 & putative poly(A) polymerase & $-1,06$ \\
\hline SCESMY4003G04 & ligand-gated channel-like protein precursor [imported] - Arabidopsis thaliana & $-0,96$ \\
\hline SCESMY2005A03 & cytochrome P450 monooxygenase [Zea mays] & $-0,86$ \\
\hline SCESMY2003B08 & hypothetical protein FG11049.1 [Gibberella zeae PH-1] & $-0,72$ \\
\hline SCESMY2005F08 & Cluster sem notação & $-0,59$ \\
\hline SCESMY1001G02 & COG0477: Permeases of the major facilitator superfamily [Azotobacter vinelandii] & 0,54 \\
\hline SCESMY2008F07 & $\begin{array}{l}\text { sp|P12857|ADT2_MAIZE ADP,ATP CARRIER PROTEIN } 2 \text { PRECURSOR } \\
\text { (ADP/ATP TRANSLOCASE 2) (ADENINE NUCLEOTIDE TRANSLOCATOR 2) }\end{array}$ & 0,60 \\
\hline SCESMY2005G03 & gb|AAB95279.1| (AF002109) unknown protein [Arabidopsis thaliana] & 0,63 \\
\hline SCESMY2009D10 & probable tonoplast aquaporin - maize & 0,64 \\
\hline SCESMY2004E03 & dynamin-like protein 4 (ADL4) & 0,72 \\
\hline SCESMY1002D10 & Putative regulatory protein [Bordetella bronchiseptica RB50] & 0,74 \\
\hline SCESMY3005A09 & putative protein & 0,84 \\
\hline SCESMY2001B08 & serine/threonine kinase-like protein & 0,88 \\
\hline SCESMY2001B06 & putative ubiquitin-specific protease otubain 1 [Oryza sativa (japonica cultivar-group)] & 0,90 \\
\hline SCESMY2008A09 & $\begin{array}{l}\text { pir||T47701 translation initiation factor eIF-6-like protein [imported] - Arabidopsis } \\
\text { thaliana }\end{array}$ & 0,91 \\
\hline SCESMY3008H09 & EXIT & 0,91 \\
\hline SCESMY2005D08 & $\begin{array}{l}\text { sp|O22212|YG62_ARATH HYPOTHETICAL 61.8 KD TRP-ASP REPEATS } \\
\text { CONTAINING PROTEIN T32G6.2 IN CHROMOSOME II }\end{array}$ & 0,95 \\
\hline SCESMY3004D02 & ribosomal protein S26 & 1,02 \\
\hline SCESMY2003F04 & $\begin{array}{l}\text { dbj|BAB08667.1| (AB018109) gene_id:K17N15.6 unknown protein [Arabidopsis } \\
\text { thaliana] }\end{array}$ & 1,03 \\
\hline SCESMY2001B01 & P0692C11.18 [Oryza sativa (japonica cultivar-group)] & 1,08 \\
\hline SCESMY2001A01 & cluster sem notação & 1,13 \\
\hline
\end{tabular}


Tabela 7 - Genes com expressão diferencial em raízes não-inoculadas e cultivadas em 200 mg P $\mathrm{kg}^{-1}$ comparadas com raizes não-inoculadas e cultivadas em $20 \mathrm{mg} \mathrm{P} \mathrm{kg}^{-1}$

\begin{tabular}{|c|c|c|}
\hline Cluster & Blast & $\mathbf{M}$ \\
\hline SCESMY2001H04 & $\begin{array}{l}\text { elongation factor } 1 \text { gamma-like protein [Oryza sativa (japonica cultivar-group)] } \\
\end{array}$ & 1,14 \\
\hline SCESMY3002F12 & aldehyde oxidase & 1,14 \\
\hline SCESMY4002B03 & cluster sem notação & 1,16 \\
\hline SCESMY2004E01 & drought-inducible cysteine proteinase RD19A precursor & 1,18 \\
\hline SCESMY3001C06 & $\begin{array}{l}\text { probable malate dehydrogenase (oxaloacetate-decarboxylating) (NADP+) (EC } \\
\text { 1.1.1.40) - maize }\end{array}$ & 1,19 \\
\hline SCESMY2005G12 & $\begin{array}{l}\text { gb|AAD37698.1|AF145729_1 (AF145729) homeodomain leucine zipper protein } \\
\text { [Oryza sativa] }\end{array}$ & 1,19 \\
\hline SCESMY2008A08 & similar to putative regulatory protein AtsB of Klebsiella pneumoniae & 1,26 \\
\hline SCESMY4003C02 & scarecrow-like 1 [Arabidopsis thaliana] & 1,28 \\
\hline SCESMY4003A04 & tetratricopeptide repeat(TPR)-containing protein-like [Oryza sativa & 1,30 \\
\hline SCESMY4003B05 & unknown protein [Arabidopsis thaliana] & 1,31 \\
\hline SCESMY2005F01 & pir||T49273 hypothetical protein T21J18.40 - Arabidopsis thaliana & 1,37 \\
\hline SCESMY2005B05 & $\begin{array}{l}\text { dbj|BAA90498.1| (AP001111) rice ESTs AA754121, AW155454, D48581 } \\
\text { correspond to a region of the predicated gene; unknown }\end{array}$ & 1,42 \\
\hline SCESMY2005C06 & FRAAN 40S RIBOSOMAL PROTEIN S23 (S12) & 1,49 \\
\hline SCESMY2004D02 & histon $\mathrm{H} 3$ protein & 1,51 \\
\hline SCESMY2005H03 & gb|AAF86550.1|AC069252_9 (AC069252) F2E2.14 [Arabidopsis thaliana] & 1,54 \\
\hline SCESMY2003B09 & Cluster sem anotação & 1,55 \\
\hline SCESMY2008E04 & pir||T49120 serine/threonine protein kinase like protein & 1,55 \\
\hline SCESMY2001D05 & heterochromatin protein homolog (Homo sapiens) & 1,56 \\
\hline SCESMY1003E03 & probable 3-hydroxybutyryl-CoA dehydrogenase [Bordetella parapertussis 12822] & 1,58 \\
\hline SCESMY3008D05 & homeotic protein Hox2a - maize & 1,62 \\
\hline SCESMY3002C10 & MADS box protein 1 [Zea mays] & 1,67 \\
\hline SCESMY3003H02 & dnaJ protein homolog atj3 & 1,68 \\
\hline SCESMY4002E07 & elongation factor EF-2 [Arabidopsis thaliana] & 1,87 \\
\hline SCESMY4002G05 & unknown protein [Oryza sativa] & 2,08 \\
\hline SCESMY1003F06 & COG1960: Acyl-CoA dehydrogenases [Pseudomonas fluorescens PfO-1] & 2,08 \\
\hline SCESMY3005D02 & Cluster sem notação & 2,12 \\
\hline SCESMY2008H05 & $\begin{array}{l}\text { sp|P38385|S61G_ORYSA PROTEIN TRANSPORT PROTEIN SEC61 GAMMA } \\
\text { SUBUNIT }\end{array}$ & 2,17 \\
\hline SCESMY2005F05 & hypothetical protein [Yarrowia lipolytica] & 2,25 \\
\hline SCESMY1002B09 & $\begin{array}{l}\text { COG0155: Sulfite reductase, beta subunit (hemoprotein) [Pseudomonas syringae pv. } \\
\text { syringae B728a] }\end{array}$ & 2,27 \\
\hline SCESMY1001B03 & $\begin{array}{l}\text { gb|AAD45991.1|AC005916_3 (AC005916) Similar to gb|AF151884 CGI-126 protein } \\
\text { from Homo sapiens. EST gb|Z18048 comes from }\end{array}$ & 2,30 \\
\hline SCESMS1001G10 & rRNA intron-encoded homing endonuclease [Oryza sativa] & 2,40 \\
\hline SCESMY2009F07 & $\begin{array}{l}\text { Membrane carboxypeptidase (penicillin-binding protein) [Pseudomonas fluorescens } \\
\text { PfO-1] }\end{array}$ & 2,50 \\
\hline SCESMY3003B06 & Cluster sem notação & 2,66 \\
\hline SCESMY4001B07 & mitogen-activated protein kinase MMK2 (EC 2.7.1.-) - alfalfa & 2,73 \\
\hline SCESMY3007C12 & vacuolar $\mathrm{H}(+)$-ATPase subunit-like protein & 2,76 \\
\hline SCESMY1002A10 & hypothetical protein [Photorhabdus luminescens subsp. laumondii TTO1] & 2,85 \\
\hline SCESMY2001F03 & COG0598: Mg2+ and Co2+ transporters [Pseudomonas fluorescens PfO-1] & 2,89 \\
\hline
\end{tabular}


Tabela 7 - Genes com expressão diferencial em raízes não-inoculadas e cultivadas em 200 mg P $\mathrm{kg}^{-1}$ comparadas com raizes não-inoculadas e cultivadas em $20 \mathrm{mg} \mathrm{P} \mathrm{kg}{ }^{-1}$

\begin{tabular}{llc} 
& & (conclusão) \\
\hline Cluster & Blast & M \\
\hline SCESMY2005D02 & sp|Q42456|APR1_ORYSA ASPARTIC PROTEINASE ORYZASIN 1 PRECURSOR & 3,37 \\
SCESMY2008H12 & sp|P40280|H2A_MAIZE HISTONE H2A >gi|7439704|pir||T02076 histone H2A - & 3,40 \\
& maize & 3,52 \\
SCESMY1002G04 & pir||T47879 hypothetical protein T4C21.90 - Arabidopsis thaliana & \\
& >gi|7329678|emb|CAB82672.1| (AL162295) putative protei & 3,86 \\
SCESMY2004A02 & hypothetical protein [Neurospora crassa] & 4,17 \\
SCESMS1008A04 & proprotein convertase aPC6C isoform & 4,23 \\
SCESMY1001D11 & putative protein & 5,06 \\
SCESMY3006A08 & pre-mRNA splicing factor SF2p33 & 5,23 \\
SCESMY4003H05 & high pI alpha-glucosidase [Hordeum vulgare] &
\end{tabular}


Tabela 8 - Genes com expressão diferencial em raízes colonizadas por Glomus clarum e cultivadas em $200 \mathrm{mg} \mathrm{P} \mathrm{kg}{ }^{-1}$ comparadas com raizes colonizadas por Glomus clarum e cultivadas em $20 \mathrm{mg} \mathrm{P} \mathrm{kg}^{-1}$

\begin{tabular}{|c|c|c|}
\hline & & int \\
\hline Cluster & Blast & $\mathbf{M}$ \\
\hline SCESMY3004E05 & S-adenosylmethionine synthase 2 & $\overline{-3,14}$ \\
\hline SCESMY2009A02 & caffeic acid 3-O-Methyltransferase [Saccharum officinarum] & $-2,60$ \\
\hline SCESMY2004C11 & Cluster sem notação & $-2,38$ \\
\hline SCESMY2003G06 & $\begin{array}{l}\text { pir||T00809 hypothetical protein T32G6.5 - Arabidopsis thaliana } \\
\text { >gi|2618688|gb|AAB84335.1| (AC002510) putative esterase }\end{array}$ & $-2,36$ \\
\hline SCESMY3003F08 & Cluster sem notação & $-2,35$ \\
\hline SCESMY4002B04 & putative pyrophosphate-dependent phosphofructo-1-kinase [Oryza sativa] & $-2,24$ \\
\hline SCESMY2008H12 & $\begin{array}{l}\text { sp|P40280|H2A_MAIZE HISTONE H2A >gi|7439704|pir||T02076 histone H2A - } \\
\text { maize }\end{array}$ & $-2,17$ \\
\hline SCESMY2003A09 & $\begin{array}{l}\text { contains ESTs AU097436(S4951),D41930(S4951),AU101944(S2163), } \\
\text { AU095016(E50186),AU058216(E5018 }\end{array}$ & $-2,17$ \\
\hline SCESMY2009E09 & $\begin{array}{l}\text { unknown protein [Arabidopsis thaliana]; } 135 \text { mucin 2, intestinal (GB:L21998) } \\
\text { (Homo sapiens); }\end{array}$ & $-2,02$ \\
\hline SCESMY2005F03 & Cluster sem notação & $-1,69$ \\
\hline SCESMY4002B03 & cluster sem notação & $-1,69$ \\
\hline SCESMY2004E09 & hypothetical protein [Oryza sativa (japonica cultivar-group)] & $-1,68$ \\
\hline SCESMY2009E05 & $\begin{array}{l}\text { H+-transporting ATPase (EC 3.6.1.35) - maize ; H+-transporting ATPase (EC } \\
\text { 3.6.1.35) - maize ; H+-transporting ATPase type 2, plasma membrane (a.thaliana) } \\
948 \text { aa }\end{array}$ & $-1,64$ \\
\hline SCESMY2003C09 & $\begin{array}{l}\text { hypothetical protein [Arabidopsis thaliana] ; MAL5, MUC1 glucoamylase s1/s2 } \\
\text { precursor (glucan 1,4-alpha-glucosidase) (1,4- alpha-D-glucan glucohydrolase) } \\
\text { [EC:3.2.1.3] }\end{array}$ & $-1,60$ \\
\hline SCESMY2001F03 & COG0598: Mg2+ and Co2+ transporters [Pseudomonas fluorescens PfO-1] & $-1,52$ \\
\hline SCESMY3006D12 & Cluster sem notação & $-1,18$ \\
\hline SCESMY2005D02 & $\begin{array}{l}\text { sp|Q42456|APR1_ORYSA ASPARTIC PROTEINASE ORYZASIN } 1 \\
\text { PRECURSOR }\end{array}$ & $-1,15$ \\
\hline SCESMY2008A06 & $\begin{array}{l}\text { emb|CAA13175.1| (AJ231133) caffeic acid 3-O-Methyltransferase [Saccharum } \\
\text { officinarum] }\end{array}$ & $-1,04$ \\
\hline SCESMY1003H05 & ubiquitin conjugating enzyme E2 (UBC13) & $-0,97$ \\
\hline SCESMY2008A10 & emb|CAC21392.1| (AJ401275) peroxidase [Zea mays] & $-0,90$ \\
\hline SCESMS1002C04 & caffeoyl-CoA O-methyltransferase - like protein & $-0,89$ \\
\hline SCESMY2008C05 & Cluster sem notação & $-0,83$ \\
\hline SCESMY2008A09 & $\begin{array}{l}\text { pir||T47701 translation initiation factor eIF-6-like protein [imported] - Arabidopsis } \\
\text { thaliana }\end{array}$ & $-0,79$ \\
\hline SCESMY3001G02 & DHAB_ORYSA BETAINE-ALDEHYDE DEHYDROGENASE (BADH) & $-0,70$ \\
\hline SCESMY3002F12 & aldehyde oxidase & $-0,66$ \\
\hline SCESMY2001C02 & methionine synthase protein [Sorghum bicolor] & $-0,42$ \\
\hline SCESMY3003C12 & 60S ribosomal protein L39 & 0,47 \\
\hline SCESMY3008C02 & probable acetolactate synthase large subunit [Pseudomonas aeruginosa PA01] & 0,48 \\
\hline SCESMY4003B05 & unknown protein [Arabidopsis thaliana] & 0,59 \\
\hline SCESMY1002D06 & hypothetical protein [Oryza sativa (japonica cultivar-group)] & 0,66 \\
\hline SCESMY2003G10 & $\begin{array}{l}\text { ABC transporter, substrate binding protein [oligopeptide] [Agrobacterium } \\
\text { tumefaciens str. C58] }\end{array}$ & 0,74 \\
\hline SCESMY3006B02 & unknown protein [Arabidopsis thaliana] & 0,78 \\
\hline SCESMY2004C01 & polyubiquitin [Sporobolus stapfianus] & 0,83 \\
\hline
\end{tabular}


Tabela 8 - Genes com expressão diferencial em raízes colonizadas por Glomus clarum e cultivadas em $200 \mathrm{mg} \mathrm{P} \mathrm{kg}^{-1}$ comparadas com raizes colonizadas por Glomus clarum e cultivadas em $20 \mathrm{mg} \mathrm{P} \mathrm{kg}^{-1}$

(continuação)

\begin{tabular}{|c|c|c|}
\hline Cluster & Blast & $\mathbf{M}$ \\
\hline SCESMY2005B08 & RNA binding protein Rp120 [Oryza sativa (japonica cultivar-group)] & 0,89 \\
\hline SCESMY3005H12 & putative cytochrome b5 & 0,89 \\
\hline SCESMY1002B09 & $\begin{array}{l}\text { COG0155: Sulfite reductase, beta subunit (hemoprotein) [Pseudomonas syringae pv. } \\
\text { syringae B728a] }\end{array}$ & 0,92 \\
\hline SCESMY2004H04 & SYMBIOTIC AMMONIUM TRANSPORTER; NODULIN [GLYCINE MAX] & 0,96 \\
\hline SCESMY2001B08 & serine/threonine kinase-like protein & 1,01 \\
\hline SCESMY4002E07 & elongation factor EF-2 [Arabidopsis thaliana] & 1,01 \\
\hline SCESMY1003B03 & isovaleryl-CoA dehydrogenase [Bordetella bronchiseptica RB50] & 1,02 \\
\hline SCESMY1003G07 & cluster sem notação & 1,04 \\
\hline SCESMY2009F07 & $\begin{array}{l}\text { Membrane carboxypeptidase (penicillin-binding protein) [Pseudomonas fluorescens } \\
\text { PfO-1] }\end{array}$ & 1,06 \\
\hline SCESMY2008F05 & $\begin{array}{l}\text { sp|P93768|PSD3_TOBAC 26S PROTEASOME REGULATORY SUBUNIT S3 } \\
\text { (NUCLEAR ANTIGEN 21D7) }\end{array}$ & 1,08 \\
\hline SCESMY2009D10 & probable tonoplast aquaporin - maize & 1,09 \\
\hline SCESMY1001D06 & putative small nuclear ribonucleoprotein polypeptide F & 1,11 \\
\hline SCESMY4003A04 & tetratricopeptide repeat(TPR)-containing protein-like [Oryza sativa & 1,11 \\
\hline SCESMY2003H09 & Cluster sem notação & 1,12 \\
\hline SCESMY2005F05 & hypothetical protein [Yarrowia lipolytica] & 1,14 \\
\hline SCESMY2001A02 & cluster sem notação & 1,17 \\
\hline SCESMY2003C08 & $\begin{array}{l}\text { MT1_ORYSA METALLOTHIONEIN-LIKE PROTEIN TYPE } 1 \text {; metallothionein } \\
\text { 2b }\end{array}$ & 1,18 \\
\hline SCESMY1002F05 & arabinogalactan protein - like & 1,25 \\
\hline SCESMY2001C06 & putative tryptophan synthase alpha chain [Oryza sativa (japonica cultivar-group)] & 1,26 \\
\hline SCESMY2003F12 & $\begin{array}{l}\text { sp|P54774|CC48_SOYBN CELL DIVISION CYCLE PROTEIN } 48 \text { HOMOLOG } \\
\text { (VALOSIN CONTAINING PROTEIN HOMOLOG) (VCP) }\end{array}$ & 1,27 \\
\hline SCESMY1003F05 & MtN3-like protein & 1,31 \\
\hline SCESMY2008D09 & Cluster sem notação & 1,31 \\
\hline SCESMY2009B08 & protein kinase-like [Arabidopsis thaliana] & 1,31 \\
\hline SCESMY3005F09 & putative poly(A) polymerase & 1,34 \\
\hline SCESMY4002G02 & $\begin{array}{l}\text { TPIC_SECCE TRIOSEPHOSPHATE ISOMERASE, CHLOROPLAST } \\
\text { PRECURSOR (TIM) }\end{array}$ & 1,38 \\
\hline SCESMY3008F12 & profilin 5 [Zea mays] & 1,41 \\
\hline SCESMY2003H06 & 60S ribosomal protein L35 [Euphorbia esula] & 1,46 \\
\hline SCESMY2009A05 & eukaryotic initiation factor 3E subunit [Arabidops & 1,48 \\
\hline SCESMY1001D08 & COG0583: Transcriptional regulator [Pseudomonas fluorescens PfO-1] & 1,50 \\
\hline SCESMY2001E05 & pyoverdine synthetase A [Pseudomonas fluorescens] & 1,55 \\
\hline SCESMY1001E09 & $\begin{array}{l}\text { COG2610: H+/gluconate symporter and related permeases [Pseudomonas syringae } \\
\text { pv. syringae B728a] }\end{array}$ & 1,55 \\
\hline SCESMY2008B07 & unknown protein [Oryza sativa (japonica cultivar-group)] & 1,57 \\
\hline SCESMY3002C10 & MADS box protein 1 [Zea mays] & 1,59 \\
\hline SCESMY1002D01 & $\begin{array}{l}\text { COG0477: Permeases of the major facilitator superfamily [Burkholderia cepacia } \\
\text { R18194] }\end{array}$ & 1,61 \\
\hline SCESMY1002F06 & putative fructose-bisphosphate aldolase, plastidic form & 1,63 \\
\hline SCESMY1001G03 & EXIT & 1,68 \\
\hline
\end{tabular}


Tabela 8 - Genes com expressão diferencial em raízes colonizadas por Glomus clarum e cultivadas em $200 \mathrm{mg} \mathrm{P} \mathrm{kg} \mathrm{g}^{-1}$ comparadas com raizes colonizadas por Glomus clarum e cultivadas em $20 \mathrm{mg} \mathrm{P} \mathrm{kg}^{-1}$

\begin{tabular}{|c|c|c|}
\hline & & (̧̧аO) \\
\hline Cluster & Blast & $\mathbf{M}$ \\
\hline$\overline{\text { SCESMS1002F07 }}$ & elongation factor 1-alpha [Zea mays] & $\overline{1,69}$ \\
\hline SCESMS1001A02 & hypotetical protein [Oryza sativa (japonica cultivar-group)] & 1,73 \\
\hline SCESMY2003H01 & $\begin{array}{l}\text { dbj|BAB09871.1| (AB008268) emb|CAB89373.1 gene_id:MSJ1.24 similar to } \\
\text { unknown protein [Arabidopsis thaliana] }\end{array}$ & 1,74 \\
\hline SCESMY4003B02 & hypothetical protein [Arabidopsis thaliana] & 1,77 \\
\hline SCESMY4003A05 & polynucleotide adenylyltransferase homolog T16I18.60 - Arabidopsis thaliana & 1,81 \\
\hline SCESMY2001G12 & type 1 rice metallothionein-like gene; & 1,83 \\
\hline SCESMY1001H02 & $\begin{array}{l}\text { COG1879: ABC-type sugar transport system, periplasmic component [Azotobacter } \\
\text { vinelandii] }\end{array}$ & 1,89 \\
\hline SCESMY2001C09 & (AP002855) hypothetical protein [Oryza sativa] & 1,89 \\
\hline SCESMY1001B03 & $\begin{array}{l}\text { gb|AAD45991.1|AC005916_3 (AC005916) Similar to gb|AF151884 CGI-126 protein } \\
\text { from Homo sapiens. EST gb|Z18048 comes from }\end{array}$ & 1,91 \\
\hline SCESMY2008F09 & pir||T48437 hypothetical protein T32M21.10 - Arabidopsis thaliana & 1,93 \\
\hline SCESMY4002F02 & similar to unknown protein [Arabidopsis thaliana] & 1,94 \\
\hline SCESMY1001D01 & COG0607: Rhodanese-related sulfurtransferase [Azotobacter vinelandii] & 1,94 \\
\hline SCESMY2004E03 & dynamin-like protein 4 (ADL4) & 1,97 \\
\hline SCESMS1002D02 & Ac1147 [Rattus norvegicus] & 1,98 \\
\hline SCESMS1008C06 & synapsin I, alt. transcript 1 (Homo sapiens) & 1,98 \\
\hline SCESMY4002E10 & Similar to Arabidopsis thaliana gamma-adaptin 1 mRNA, complete cds. & 1,99 \\
\hline SCESMY1003E06 & translation initiation factor 4D (Homo sapiens) & 2,03 \\
\hline SCESMY4002A12 & hydrolase (HAD superfamily) [Bacillus cereus ATCC 14579] & 2,04 \\
\hline SCESMY3008F05 & $\begin{array}{l}\text { probable acetolactate synthase large subunit [Pseudomonas aeruginosa PA01] } \\
\text { gb|AAG08362.1| probable acetolactate synthase large subunit [Pseudomonas } \\
\text { aeruginosa PAO1] pir||G83024 probable acetolactate synthase large subunit PA4977 } \\
\text { [imported] - Pseudomo }\end{array}$ & 2,05 \\
\hline SCESMY1003F01 & $\begin{array}{l}\text { COG2133: Glucose/sorbosone dehydrogenases [Pseudomonas syringae pv. syringae } \\
\text { B728a] }\end{array}$ & 2,05 \\
\hline SCESMY4001B01 & Acyl-CoA dehydrogenases [Pseudomonas fluorescens PfO-1] & 2,09 \\
\hline SCESMY2004F08 & hypothetical protein [Oryza sativa] & 2,12 \\
\hline SCESMY2009D12 & strong similarity to unknown protein [Arabidopsis thaliana] & 2,16 \\
\hline SCESMY2004F09 & $\begin{array}{l}\text { L-alanine-DL-glutamate epimerase and related enzymes of enolase superfamily } \\
\text { [Pseudomonas fluorescens PfO-1] }\end{array}$ & 2,17 \\
\hline SCESMY2001C04 & $\begin{array}{l}\text { COG1020: Non-ribosomal peptide synthetase modules and related proteins } \\
\text { [Pseudomonas fluorescens PfO-1] }\end{array}$ & 2,27 \\
\hline SCESMY2008A11 & metallothionein $2 \mathrm{~b}$ & 2,27 \\
\hline SCESMY3005G03 & eIF-4a eIF-4a gene product & 2,31 \\
\hline SCESMY3005C07 & cyclophylin -like protein & 2,32 \\
\hline SCESMY1002B01 & $\begin{array}{l}\text { COG1020: Non-ribosomal peptide synthetase modules and related proteins } \\
\text { [Pseudomonas fluorescens PfO-1] }\end{array}$ & 2,34 \\
\hline SCESMY4003G04 & ligand-gated channel-like protein precursor [imported] - Arabidopsis thaliana & 2,39 \\
\hline SCESMY4001C06 & diaminobutyrate--pyruvate aminotransferase [Bordetella p & 2,41 \\
\hline SCESMY1001G07 & $\begin{array}{l}\text { COG1020: Non-ribosomal peptide synthetase modules and related proteins } \\
\text { [Pseudomonas fluorescens PfO-1] }\end{array}$ & 2,43 \\
\hline SCESMY2005D05 & metallothionein $2 \mathrm{~b}$ & 2,45 \\
\hline SCESMY1003D10 & mucin 2, intestinal (GB:L21998) (Homo sapiens) & 2,49 \\
\hline
\end{tabular}


Tabela 8 - Genes com expressão diferencial em raízes colonizadas por Glomus clarum e cultivadas em $200 \mathrm{mg} \mathrm{P} \mathrm{kg}{ }^{-1}$ comparadas com raizes colonizadas por Glomus clarum e cultivadas em $20 \mathrm{mg} \mathrm{P} \mathrm{kg}^{-1}$

\begin{tabular}{|c|c|c|}
\hline Cluster & Blast & M \\
\hline SCESMY1003F08 & $\begin{array}{l}\text { Similarity to Yeast uridine kinase (SP:URK1_YEAST) [EC:2.7.1.48] (c.elegans) } 515 \\
\text { aa }\end{array}$ & 2,50 \\
\hline SCESMY4001D07 & similar to putative reverse transcriptase (AC005315) [Oryza sativa] & 2,5 \\
\hline SCESMY4001A07 & similar to unknown protein [Arabidopsis thaliana] & 2,6 \\
\hline SCESMY3007C12 & vacuolar $\mathrm{H}(+)$-ATPase subunit-like protein & 2,6 \\
\hline SCESMY2001B06 & putative ubiquitin-specific protease otubain 1 [Oryza sativa (japonica cultivar-group)] & 2,7 \\
\hline SCESMY4001G03 & Osmosensitive K+ channel histidine kinase [Pseudomonas fluorescens PfO-1] & 2,71 \\
\hline SCESMY4001A04 & TBA1_ELEIN TUBULIN ALPHA-1 CHAIN (ALPHA-TUBULIN 1) & 2,72 \\
\hline SCESMY4001G05 & $\begin{array}{l}\text { D-isomer specific 2-hydroxyacid dehydrogenase family protein [Pseudomonas putida } \\
\text { KT2440] }\end{array}$ & 2,78 \\
\hline SCESMY1001C06 & adenosylhomocysteinase & 2,78 \\
\hline SCESMY4002E05 & Signal transduction histidine kinase [Pseudomonas fluorescens PfO-1] & 2,86 \\
\hline SCESMY2008B11 & $\begin{array}{l}\text { emb|CAC27017.1| (AJ010592) ubiquitin-conjugating enzyme E2-21 KD [Guillardia } \\
\text { theta] }\end{array}$ & 2,9 \\
\hline SCESMY1001H05 & collagen, type I, alpha 2 (Homo sapiens) & 2,9 \\
\hline SCESMY2004E08 & GcpE protein [Arabidopsis thaliana] & 2,92 \\
\hline SCESMY1003F09 & thioredoxin h & 3,01 \\
\hline SCESMY4001H05 & Signal transduction histidine kinase [Microbulbifer degradans 2-40] & 3,0 \\
\hline SCESMY2001A06 & elongation factor 1-alpha [Zea mays] & 3,03 \\
\hline SCESMY1001F02 & unknown protein & 3,09 \\
\hline SCESMY4003C02 & scarecrow-like 1 [Arabidopsis thaliana] & 3,1 \\
\hline SCESMY1002G09 & 14-3-3-LIKE PROTEIN GF14 UPSILON & 3,1 \\
\hline SCESMY1003C02 & phosphate ABC transporter, permease protein [Pseudomonas putida KT2440] & 3,23 \\
\hline SCESMY2001A07 & putative senescence-associated protein [Pisum sativum] & 3,2 \\
\hline SCESMY1001D11 & putative protein & 3,2 \\
\hline SCESMY4001D03 & Outer membrane receptor proteins, mostly Fe transport [Pseudomonas aeruginosa & 3,3 \\
\hline SCESMY4003G03 & Permeases of the major facilitator superfamily [Pseudomonas fluorescens PfO-1] & 3,6 \\
\hline SCESMY1001E01 & protein kinase -like protein & 3,7 \\
\hline SCESMS1001G10 & rRNA intron-encoded homing endonuclease [Oryza sativa] & 3,9 \\
\hline SCESMY4003E02 & F21B7.1 [Arabidopsis thaliana] & 4,0 \\
\hline SCESMS1008A04 & proprotein convertase aPC6C isoform & 4,1 \\
\hline SCESMY4001H07 & conserved hypothetical protein [Pseudomonas syringae pv. tomato str. DC3000] & 4,1 \\
\hline SCESMY3003F01 & AIG1-like protein & 4,2 \\
\hline SCESMY1001A11 & COG2831: Hemolysin activation/secretion protein [Pseudomonas fluorescens PfO-1] & 4,3 \\
\hline SCESMY4001H06 & $\begin{array}{l}\text { transcriptional regulator, LysR family [Pseudomonas syringae pv. tomato str. } \\
\text { DC3000] }\end{array}$ & 4, \\
\hline SCESMY3004D03 & unknown protein [Arabidopsis thaliana] & 4,6 \\
\hline SCESMY2005G02 & $\begin{array}{l}\text { dbj|BAA85422.1| (AP000616) similar to putative reverse transcriptase (AC005315) } \\
\text { [Oryza sativa] }\end{array}$ & 5,1 \\
\hline SCESMY3006A08 & pre-mRNA splicing factor SF2p33 & 5,2 \\
\hline SCESMY2004A02 & hypothetical protein [Neurospora crassa] & 5,2 \\
\hline
\end{tabular}

Tabela 8 - Genes com expressão diferencial em raízes colonizadas por Glomus clarum e cultivadas em $200 \mathrm{mg} \mathrm{P} \mathrm{kg} \mathrm{g}^{-1}$ comparadas com raizes colonizadas por Glomus clarum e cultivadas em $20 \mathrm{mg} \mathrm{P} \mathrm{kg}^{-1}$ 
(conclusão)

\begin{tabular}{llc}
\hline Cluster & Blast & M \\
\hline SCESMS1008F10 & metallothionein 2b & 5,96 \\
SCESMY1003D01 & mucin 2, intestinal (GB:L21998) (Homo sapiens) & 6,02 \\
SCESMY2004H06 & putative Ca2+ dependent protein kinase & 7,69 \\
SCESMY2004B03 & MT-like protein [Cynodon dactylon] & 7,72 \\
SCESMY2004D03 & putative DNA-binding protein & 7,97 \\
SCESMY4003C05 & hypothetical protein b1956 [Escherichia coli K12] & 8,06 \\
SCESMY2004G03 & putative beta-1,3-glucanase & 8,26 \\
SCESMY2001H02 & hypothetical protein FG04948.1 [Gibberella zeae PH-1] & 8,35 \\
SCESMY2005H03 & gb|AAF86550.1|AC069252_9 (AC069252) F2E2.14 [Arabidopsis thaliana] & 8,59 \\
SCESMY3005B05 & histon H3 protein & 9,02 \\
SCESMY3006H06 & catalase & 9,16 \\
SCESMY1002G04 & pir||T47879 hypothetical protein T4C21.90 - Arabidopsis thaliana & 9,16 \\
& >gi|7329678|emb|CAB82672.1| (AL162295) putative protei & 10,20 \\
SCESMY1001H11 & polyubiquitin (ubq10) & \\
\hline
\end{tabular}


Tabela 9 - Genes com expressão diferencial em raízes não-inoculadas e cultivadas em 200 mg P $\mathrm{kg}^{-1}$ comparadas com raizes colonizadas por Glomus clarum e cultivadas em $20 \mathrm{mg} \mathrm{P}$ (continua)

\begin{tabular}{l}
\hline Cluster \\
\hline SCESMY3005F09 \\
SCESMY4002B02 \\
SCESMY1002B01 \\
SCESMY2009H09 \\
SCESMY2004F12 \\
SCESMY1003F09 \\
SCESMY2001F10 \\
SCESMY1001D08 \\
SCESMY2009G03
\end{tabular}

SCESMY1003F01

SCESMY2003D01 SCESMY1003F05 SCESMY3005H12 SCESMY2005G03 SCESMY3002F12 SCESMY2008B05 SCESMY2003F12

SCESMY2001E03

SCESMY2003B09

SCESMY3008F12

SCESMY2005E01

SCESMY2001E06 SCESMY2003E01

SCESMY3003H02

SCESMY2001A12

SCESMY3008H09

SCESMY2008F11

SCESMY4003B05

SCESMY2001C09

SCESMY3004E06

SCESMY2004D03

SCESMY2008F03

SCESMY1003A02

SCESMY4001D07

SCESMY1002G04

SCESMY2003H09

SCESMY3005A09

Blast putative poly(A) polymerase $-2,43$ hypothetical protein T10P11.3.2 - Arabidopsis thaliana $\quad-1,98$ COG1020: Non-ribosomal peptide synthetase modules and related proteins $\quad-1,53$ [Pseudomonas fluorescens PfO-1] AraC-type DNA-binding domain-containing proteins [Pseudomonas fluorescens PfO- - -1,46 1]

ABC transporter homolog PnATH - like $\quad-1,43$ thioredoxin $h \quad-1,39$

40S ribosomal protein S16 $-1,35$

COG0583: Transcriptional regulator [Pseudomonas fluorescens PfO-1] $\quad-1,07$

nodulin protein-like [Arabidopsis thaliana] ; putative integral membrane protein $\quad-1,03$ nodulin

COG2133: Glucose/sorbosone dehydrogenases [Pseudomonas syringae pv. syringae $\quad-0,97$ B728a]

putative U5 small nuclear ribonucleoprotein, an RNA helicase $\quad-0,62$

MtN3-like protein $\quad-0,60$

putative cytochrome b5 $\quad-0,50$

gb|AAB95279.1| (AF002109) unknown protein [Arabidopsis thaliana] $\quad-0,45$

aldehyde oxidase $\quad-0,42$

pir||T49211 hypothetical protein F27K19.170 - Arabidopsis thaliana $\quad-0,41$

sp|P54774|CC48_SOYBN CELL DIVISION CYCLE PROTEIN 48 HOMOLOG $\quad-0,33$

(VALOSIN CONTAINING PROTEIN HOMOLOG) (VCP)

putative cytochrome P450-related protein [Oryza sativa] $\quad 0,52$

Cluster sem anotação $\quad 0,54$

profilin 5 [Zea mays] $\quad 0,60$

conserved hypothetical protein [Salmonella enterica subsp. enterica serovar Typhi str. $\quad 0,70$ CT18]

COG0515: Serine/threonine protein kinase [Pseudomonas fluorescens PfO-1] $\quad 0,72$

22 kDa drought-inducible protein [Saccharum hybrid cultivar] dbj|BAB68268.1| $\quad 0,75$

drought inducible $22 \mathrm{kD}$ protein [Saccharum officinarum]

$\begin{array}{ll}\text { dnaJ protein homolog atj3 } & 0,78\end{array}$

metallothionein-like protein type 3 [Hordeum vulgare subsp. vulgare] $\quad 0,79$

$\begin{array}{ll}\text { EXIT } & 0,83\end{array}$

pir||T04331 golgi associated protein se-wap41 - maize $\quad 0,86$

unknown protein [Arabidopsis thaliana] $\quad 0,96$

(AP002855) hypothetical protein [Oryza sativa] $\quad 1,05$

V-ATPase subunit G (vag2 gene) $\quad 1,06$

putative DNA-binding protein $\quad 1,07$

Cluster sem notação 1,14

cluster sem notação $\quad 1,21$

similar to putative reverse transcriptase (AC005315) [Oryza sativa] $\quad 1,21$

pir||T47879 hypothetical protein T4C21.90 - Arabidopsis thaliana $\quad 1,38$

>gi|7329678|emb|CAB82672.1| (AL162295) putative protei

Cluster sem notação $\quad 1,40$

putative protein $\quad 1,41$ 
Tabela 9 - Genes com expressão diferencial em raízes não-inoculadas e cultivadas em 200 mg P $\mathrm{kg}^{-1}$ comparadas com raizes colonizadas por Glomus clarum e cultivadas em $20 \mathrm{mg} \mathrm{P}$ $\mathrm{kg}^{-1}$ (conclusão)

\begin{tabular}{llr}
\hline Cluster & Blast & M \\
\hline SCESMY2001E02 & putative fatty acid hydroxylase & 1,44 \\
SCESMY2005H03 & gb|AAF86550.1|AC069252_9(AC069252) F2E2.14 [Arabidopsis thaliana] & 1,49 \\
SCESMY2008A11 & metallothionein 2b & 1,51 \\
SCESMY2008C05 & Cluster sem notação & 1,52 \\
SCESMY2001C02 & methionine synthase protein [Sorghum bicolor] & 1,58 \\
SCESMY1003G12 & COG0436: Aspartate/tyrosine/aromatic aminotransferase [Pseudomonas fluorescens & 1,58 \\
& PfO-1] & 1,68 \\
SCESMY3005B05 & histon H3 protein & 1,70 \\
SCESMY3006H06 & catalase & 1,84 \\
SCESMY1001E06 & serine/threonine kinase-like protein & 2,03 \\
SCESMY1002A10 & hypothetical protein [Photorhabdus luminescens subsp. laumondii TTO1] \\
\hline
\end{tabular}

\subsection{Discussão dos resultados}

\subsubsection{Biblioteca subtrativa supressiva}

\subsubsection{Análise dos genes que compõem a biblioteca subtrativa supressiva}

O desenvolvimento de associações micorrízicas arbusculares está associado com diversas alterações fisiológicas nas raízes da planta hospedeira e exige a expressão coordenada de vários genes. A maioria dos genes envolvidos no controle do desenvolvimento de MAs não é conhecida, e informações valiosas podem ser obtidas com a identificação de genes com expressão diferencial na simbiose.

Neste trabalho, uma biblioteca de cDNAs enriquecida em genes com expressão induzida em raízes de cana-de-açúcar colonizadas por G. clarum foi sintetizada através de subtração supressiva, com o objetivo de identificar genes com expressão diferencial em MAs.

A síntese da biblioteca subtrativa supressiva foi realizada através da metodologia desenvolvida por Diatchenko et al. (1996), onde cDNAs com maior abundância em uma amostra, em relação á uma segunda amostra, são amplificados por PCR.

Utilizando essa metodologia foram identificados 108 cDNAs possivelmente induzidos em raízes de cana-de-açúcar micorrizadas, cultivadas durante 12 semanas em condições de baixo P. Cerca de $49 \%$ dos clones desta biblioteca apresentaram alta similaridade com proproteína convertases (Anexo 2).

Proproteína convertases (PCs) estão envolvidas na ativação de uma grande variedade de substratos, dentre eles hormônios peptídicos, receptores e enzimas. Pela classificação utilizada 
pelo banco de dados SUCEST, PCs estariam relacionadas à bioenergética da célula mas, PCs também podem estar associadas à respostas ao estresse (Jorda et al., 1999). PCs semelhantes a proteases de subtilisina são induzidas em tomateiros após infecção por patógeno e pela aplicação de ácido salicílico (Jorda et al., 1999).

Outro gene relacionado a respostas a estresses com expressão induzida em raízes micorrizadas, representando por cerca de $23 \%$ dos clones desta biblioteca, apresenta alta similaridade com metalotioneína 2b. Metalotioneínas tipo II são pouco abundantes em raízes de cana-de-açúcar, sendo encontradas em maior quantidade nas inflorescências (Figueira et al., 2001). Pouco se sabe sobre suas funções e sobre a regulação das diferentes isoformas. As evidências experimentais indicam que estas proteínas podem ter papel importante na homeostase de metais, e estão, provavelmente associadas com o transporte de metais na planta. Em raízes de trevo branco (Trifolium repens) colonizadas por Gigaspora margarita foi observada a indução de metalotioneínas quando as raízes receberam Cu (Lanfranco et al., 2002).. A monitoração do gene foi feita utilizando-se como sonda um clone proveniente de bibliotecas de ESTs sintetizadas a partir de esporos e micélio pré-simbiótico de G. margarita (Stommel et al. 2001). No experimento conduzido por Lanfranco et al. (2002), o nível de expressão da metalotioneína em esporos não foi alterada pela adição de $\mathrm{Cu}$ ao meio de cultura, indicando que a indução de metalotioneínas durante o estresse por metais pesados é específica da fase simbiótica do fungo.

Outro gene possivelmente induzido em MAs é aquele que codifica cafeoil-CoA Omethiltransferase representando 3,7\% dos clones da biblioteca subtrativa. Cafeoil-CoA Omethiltransferase está envolvido na biossíntese de fitoalexinas e lignina, e foi observado sendo induzido durante a interação patógeno-hospedeiro incompatível entre aveia e o fungo patogênico Puccinia coronata f. sp. avenae demonstrando que é uma resposta de defesa vegetal induzida pela infecção por patógenos (Yang et al., 2004).

Outro gene que apresentou expressão possivelmente induzida em MAs são similares a fatores de elongação $\alpha$ e possuem papel central na síntese de proteínas e interagem com proteínas do citoesqueleto (tubulinas), sendo uma classe de proteína abundante em procariotos e eucariotos (Carneiro et al., 1999). Alguns autores consideram os fatores de elongação $\alpha$ como genes com expressão constitutiva utilizando-os como controle em seus experimentos de hibridização (Wulf et al., 2003; Liu et al., 2003). Sua possível função em MAs poderia estar associada aos rearranjos do citoesqueleto das células colonizadas por FMAs sendo que estas proteínas atuam na amarração 
dos microtúbulos, sendo que este processo pode ser suprimido por cálcio e calmodulinas (Durso \& Cyr, 1994).

Apesar da técnica de hibridização subtrativa supressiva promover o enriquecimento de populações de mRNAs em seqüências diferencialmente expressas na biblioteca, e de algumas publicações mostrarem alta eficiência desse processo para a clonagem de genes com expressão diferencial (Diatchenko et al., 1996; Gurskaya et al., 1996), na maioria dos casos o que se observa é que apenas uma parte dos clones obtidos tem sua regulação diferencial confirmada através de métodos complementares. Entre os fatores que interferem nesta eficiência, pode-se incluir: 1) o número de genes diferentes entre as duas condições; 2) a abundância relativa dos transcritos; 3) o nível de indução do gene em questão; 4) a complexidade do conjunto de expressos pela célula; 5) a magnitude dos níveis basais de expressão dos genes e; 6) o enriquecimento e a normalização da biblioteca (Rebrikov \& Kogan, 2003).

\subsubsection{Análise de expressão diferencial em macroarranjos dos genes provenientes da biblioteca subtrativa supressiva}

Os clones provenientes da biblioteca subtrativa supressiva enriquecida com genes induzidos pela colonização micorrízica em raízes cultivadas por 12 semanas em condições de baixo P foram arranjados em macroarranjos de cDNA com o objetivo de confirmar a expressão diferencial destes genes.

Dentre os genes testados, apenas cafeoil-CoA-O-metiltransferase (SCESMS1002C04) teve sua expressão diferencial confirmada em macroarranjos. Este gene teve indução de 1,8 vezes em raízes micorrizadas cultivadas em condições de baixo P. Cafeoil-CoA-O-metiltransferase está envolvida nas respostas de defesa da planta sendo que seu produto é utilizado na produção de fitoalexinas e no enrijecimento da parede celular. Em relações patógeno-hospedeiro incompatíveis, cafeoil-CoA-O-metiltransferase é induzida poucas horas após a inoculação do patógeno causando reação de hipersensibilidade e morte celular programa (Yang et al., 2004). Em micorrizas não é conhecido o papel de cafeoil-CoA-O-metiltransferase mas é possível que esteja relacionado com o aumento de resistência das plantas micorrizadas ao ataque de patógenos.

Uma proteína putativa (SCESMS1002D02) teve seu acúmulo de transcritos suprimido 3,1 vezes em raízes micorrizadas cultivadas em baixo $\mathrm{P}$ em relação aos controles não-inoculados cultivados na mesma dose de P. Esta proteína putativa apresentou acúmulo de transcritos 3,1 
vezes maior em raízes micorrizadas cultivadas em alto em relação aos controles não-inoculados cultivados na mesma dose de P. Quando comparou-se as doses de P aplicadas, o acúmulo de transcritos nos controles não-inoculados cultivados em baixo P foi 2,8 vezes menor em relação aos controles cultivados em alto $\mathrm{P}$ e, em raízes micorrizadas cultivadas em baixo $\mathrm{P}$ houve indução de 3,9 vezes no acúmulo de transcritos em relação às raízes micorrizadas cultivadas em alto P. A função desta proteína putativa é desconhecida mas devido ao perfil de acúmulo demonstrado é possível levantar hipóteses sobre a sua função em micorrizas arbusculares e provável regulação pela adubação fosfatada.

O acúmulo de transcritos com similaridade a metalotioneína 2b (SCESMS1008F10) foi 3,8 vezes menor em raízes micorrizadas cultivadas em baixo $\mathrm{P}$ em relação aos controles nãoinoculados cultivados na mesma dose de P. Em raízes micorrizadas cultivadas em alto P, o acúmulo de transcritos foi 62 vezes maior em relação a raízes micorrizadas cultivadas em baixo $\mathrm{P}$ e 100 vezes maior em relação aos controles não-inoculados cultivados em alto P. Em fungos patogênicos como Magnaporthea grisea, foi demonstrado que metalotioneínas são essenciais para a infecção do hospedeiro pelo patógeno, nesta situação, foi demonstrado que a metalotioneína é um poderoso anti-oxidante podendo atuar durante o processo de infecção como um doador de elétrons, detoxificando espécies ativas de oxigênio. Em MAs, a degradação de espécies ativas de oxigênio pode ser um eficiente mecanismo para atenuar as respostas de defesa vegetal (Lambais et al., 2003)

Em condições de alto $\mathrm{P}$, as raízes micorrizadas apresentaram acúmulo de 15,3 vezes maiores para transcritos com similaridade a uma endonuclease (SCESMS1001G10) em relação a plantas micorrizadas cultivadas em baixo P. Em raízes não-inoculadas, o acúmulo de transcritos foi 5,3 vezes naquelas cultivadas em alto $\mathrm{P}$ em relação às cultivadas em baixo $\mathrm{P}$.

Em raízes colonizadas por G. clarum, o acúmulo de transcritos com similaridade a uma proteína hipotética (SCESMS1008C06) foi 4 vezes maior em raízes cultivadas em alto P em relação às raízes cultivadas em baixo $\mathrm{P}$.

Em raízes micorrizadas cultivadas em condições de alto $\mathrm{P}$, o acúmulo de transcritos com similaridade a fator de elongação $1 \alpha$ (SCESMS1002F07) foi 5,9 vezes maior em relação aos controles não-inoculados cultivados em alto P e 3,2 vezes maior em relação a raízes micorrizadas cultivadas em baixo $\mathrm{P}$. 


\subsubsection{Bibliotecas de cDNA}

\subsubsection{Análise das bibliotecas de cDNA}

As bibliotecas de cDNA do projeto MycSUCEST foram construídas utilizando-se a mesma metodologia utilizada no projeto SUCEST descrita por Vettore et al. (2001), mas as análises de bioinformática diferiram entre os dois projetos.

Estas diferenças nas análises de bioinformática foram implementadas devido às diferenças entre os objetivos dos dois projetos. Enquanto o SUCEST teve como objetivo principal o seqüenciamento em larga escala do genoma da cana-de-açúcar, o objetivo do MycSUCEST foi construir um pequeno banco de genes a partir de raízes micorrizadas para a utilização nos demais projetos do Laboratório de Microbiologia Molecular (LMM).

A primeira alteração implementada na análise de bioinformática foi a seleção de seqüências que tivessem, no mínimo, 300 bases com qualidade Phred maior que 20, excluindo-se as seqüências do vetor. Esta alteração permitiu a exclusão de fragmentos curtos ou com baixa qualidade de análise. Isto foi importante para o processo de anotação que tornou-se mais confiável com o aumento da seqüência utilizada.

A segunda alteração implementada foi a modificação dos parâmetros do processo de clusterização utilizando no mínimo 30 bases com 90\% de similaridade para o alinhamento de seqüências em um mesmo cluster. Estes parâmetros são mais restritivos que os utilizados no SUCEST por permite apenas 3 “mismatch” dentro da seqüência “match” (enquanto o SUCEST permite 8 “mismatch” dentro da seqüência “match”).

Como o nosso objetivo foi montar um banco de ESTs para os demais projetos do LMM, não tornou-se objetivo deste trabalho o estudo de SNPs (Single Nucleotide Polimorfism Polimorfismo de um único nucleotídeo), que é importante em projetos de seqüenciamento de genomas poliplóides como o da cana-de-açúcar e por isso, esta análise já foi desenvolvida dentro do projeto SUCEST.

A classificação funcional das ESTs foi feita utilizando-se as categorias definidas pelo projeto SUCEST, sendo que foi necessária a inclusão de duas categorias adicionais para contemplar seqüências não encontradas no banco de dados do SUCEST.

Foram encontrados 13 genes fúngicos na biblioteca proveniente das raízes inoculadas. Estes genes são similares a proteínas hipotéticas de Aspergillus nidulans, Magnaporthe grisea e Gibberela zeae. Em bibliotecas provenientes de raízes não-inoculadas foi encontrado um único 
gene codificando uma proteína hipotética de Aspergilus nidulans. De acordo com os dados obtidos por Liu et al. (2003) são esperados cerca de 5\% de genes fúngicos na biblioteca, mas este valor pode variar de acordo com a porcentagem de colonização micorrízica apresentada. A porcentagem de colonização micorrízica das raízes que deram origem a biblioteca MY1 foi de 45\% em media, enquanto que as raízes utilizadas por Liu et al. (2003) apresentaram porcentagem de colonização micorrízica de 50\% em média.

Além da presença de seqüências fúngicas, as bibliotecas inoculadas apresentaram mais de 40\% de seqüências novas para o banco de dados do SUCEST. O índice de seqüências que não apresentaram similaridade significativa $\left(\mathrm{E}<10^{-20}\right.$; Kim et al., 2001) com os bancos de dados utilizados foi de máximo de $10 \%$ das seqüências analisadas.

\subsubsection{Análise da expressão gênica em Northern blot eletrônico}

A presença de enzimas ligadas ao processo de destoxificação de espécies ativas de oxigênio foram representadas por um cluster encontrado no tratamento $\mathrm{PANi}$, que apresentou similaridade com catalases. Em raízes de feijão colonizadas por G. clarum e cultivadas em altas doses de $\mathrm{P}$, houve a supressão de catalases durante os estádios iniciais da simbiose em relação às raízes não-colonizadas (Lambais et al., 2003).

As raízes colonizadas por $G$. clarum e cultivadas em baixos níveis de P apresentaram um agrupamento formado por duas sequências com similaridade a proteínas ligadas a choque térmico (Heat Shock Protein). Proteínas ligadas a choque térmico (chaperonas) são proteínas induzidas por vários tipos de estresse e podem ,também, ser induzidas pela colonização das raízes por FMA ou por altos níveis de P (Liu et al., 2003).

A sacarose é a principal forma de transporte de carboidratos em plantas superiores. Para a utilização da sacarose nos tecidos heterotróficos é necessária a sua clivagem pelas enzimas sacarose sintase e invertase. A quebra da sacarose pela sacarose sintase resulta em frutose e (UDP)-glicose que são precursores requeridos na glicólise e também importantes para a formação da parede celular (Nolte et al., 1995). Na biblioteca PBNi observou-se a expressão de sacarose sintase e mais dois genes ligados ao metabolismo de glicose (glicose dehidrogenase e dTDPglicose-4-6-dehidratase), enquanto a biblioteca PBNi apresentou apenas a expressão de sacarose sintase. Nas raízes inoculadas por G. clarum não foi detectado o gene da sacarose sintase concordando com os dados apresentados por Honjec et al. (2003) que mostram que uma isoforma 
de sacarose sintase (MtSucS1) é suprimida em células radiculares colonizadas por Glomus mosseae.

Na biblioteca PBGc foram detectados fatores de elongação EF-1 $\alpha$ e EF-1 $\gamma$ e na biblioteca subtrativa supressiva detectou-se uma única seqüência do fator de elongação EF-1 $\alpha$.

\subsubsection{Análise de expressão diferencial em macroarranjos}

\subsubsection{Genes que codificam reguladores de transcrição}

O processo de colonização de raízes por fungos micorrízicos arbusculares resulta na reorganização das estruturas celulares e em alterações específicas do metabolismo vegetal. Estas mudanças necessitam, primeiramente, de alterações na expressão gênica, através da atuação de reguladores de transcrição.

A expressão de 21 genes associados ao Metabolismo de RNA e transcrição (categoria 12) foram avaliados através de hibridização em macroarranjos de cDNA. Destes, 15 tiveram seu nível de expressão alterado em função da inoculação de raízes de cana-de-açúcar com G. clarum.

O gene codificando a proteína F2E2.14 (SCESMY2005H03) apresentou altos níveis de acúmulo em raízes colonizadas por G. clarum e cultivadas em alto P. F2E2.14 foi inicialmente detectada em A. thaliana, e apresenta similaridade com o fator de transcrição TGA3(Miao et al., 1994). Fatores de transcrição TGA estão relacionados com respostas de defesa contra patógenos (Jakoby et al., 2002). Há evidências também de seu envolvimento na regulação de glutatione-Stransferases, as quais podem ser induzidas por auxinas (Johnson et al., 2001) ou por fungos micorrízicos arbusculares em raízes de M. truncatula (Wulf et al., 2003).

Em nosso experimento, a expressão do gene codificando F2E2.14 não foi afetada pela inoculação com $G$. clarum em condições de baixo P, mas foi induzida cerca de 2,9 vezes em raízes não-inoculadas em condições de alto P, em relação a baixo P. Em raízes colonizadas por $G$. clarum cultivadas em alto $\mathrm{P}$, observou-se aumento de 161 vezes no acúmulo de transcritos codificando F2E2.14, quando comparado com raízes não-inoculadas, e aumento de 385 vezes quando comparado com raízes inoculadas cultivadas em condições de baixo P.

Também foram observadas induções significativas na expressão de genes codificando proteínas com homeodomínio ziper de leucina (homeodomain leucine zipper protein, SCESMY2005G12), uma proteína com repetições de WD ("WD-repeat protein”, SCESMY2005D08) e uma proteína ribossômica S26 em raízes não-inoculadas cultivadas em alto 
P, em relação a baixo P. O acúmulo de transcritos codificando proteínas com homodomínio ziper de leucina foi induzido cerca de 2,3 vezes em raízes cultivadas em alto P, em relação a raízes cultivadas em baixo P, e podem estar envolvidas na defesa contra patógenos (Zhou et al., 2000). O acúmulo de transcritos codificando uma proteína com repetições de WD foi induzido cerca de 1,9 vezes em raízes não-inoculadas cultivadas em alto $\mathrm{P}$, em relação às raízes não-inoculadas cultivadas em baixo P, e pode estar relacionada com transdução de sinais e controle do ciclo celular e da apoptoses (Samuilov et al., 2000). Em MAs, o P atua como o principal regulador da simbiose, ativando respostas de defesa vegetal para controlar a colonização do sistema radicular pelo fungo (Lambais et al., 2003). A atuação do P no controle da simbiose parece ocorrer anteriormente ao contato físico entre os simbiontes, pois as plantas não-inoculadas e cultivadas em altos $\mathrm{P}$ apresentam maior acúmulo de transcritos que codificam reguladores de transcrição relacionados com a defesa vegetal.

Em raízes colonizadas, altas concentrações de $\mathrm{P}$ induziram o acúmulo de transcritos codificando proteínas similares a mucina 2 (SCESMY1003D01) e uma proteína ribossômica da subunidade menor (SCESMY1001D06), em relação às raízes cultivadas em baixo P. O acúmulo de transcritos codificando mucina 2 foi induzido aproximadamente 65 vezes em raízes colonizadas e cultivadas em condições de alto P, em relação a raízes colonizadas e cultivadas em condições de baixo P. Muito embora mucina 2 não possua função conhecida em células vegetais, sua estrutura assemelha-se a de fatores de transcrição, sendo assim classificada nessa categoria do projeto SUCEST. É possível que estes fatores de transcrição juntamente com a proteína ribossomal S26, ativem a transcrição de genes associados ao sistema de defesa vegetal, dificultando a colonização intrarradicular em condições de alto P.

A colonização de raízes de cana-de-açúcar por fungos micorrízicos em condições de alto $\mathrm{P}$ induziu o acúmulo de transcritos codificando uma proteína 14-3-3 (SCESMY1002G09) e um fator de transcrição AP2, e suprimiu a expressão de uma mucina 2 (SCESMY2009E09) e de um precursor de mucina 1 (SCESMY1003B09). O aumento no acúmulo de transcritos codificando a proteína 14-3-3 em raízes colonizadas por G. clarum foi de aproximadamente 9 vezes em relação a raízes colonizadas cultivadas em condições de baixo P e de aproximadamente 10 vezes em relação a raízes não-inoculadas cultivadas em alto P. As proteínas 14-3-3 estão associadas a regulação da expressão gênica em células vegetais, devido à formação de complexos que ligamse a "boxes G” (Kuramae et al., 2001). A superexpressão do fator de transcrição AP2 em plantas 
de tabaco transformadas aumentou a tolerância destas plantas ao ataque de patógenos e ao estresse osmótico (Park et al., 2001).

\subsubsection{Genes relacionados à defesa vegetal}

Durante o desenvolvimento de MAs, têm sido observado alterações significativas no acúmulo de transcritos de genes envolvidos na defesa vegetal contra o ataque de patógenos. Estas alterações são observadas durante todo o desenvolvimento da simbiose e parecem ter papel fundamental no controle da colonização intrarradicular (Lambais \& Mehdy, 1995).

Dentre os genes relacionados à defesa vegetal, um gene codificando ácido caféico 3-Ometiltransferase (SCESMY2008A06) foi significativamente $(\mathrm{p}<0,05)$ induzido em raízes colonizadas por G. clarum (aproximadamente 2 vezes), em relação aos controles não-inoculados, tanto em condição de baixo quanto de alto P. Ácido caféico 3-O-metiltransferase está envolvida na biossíntese de lignina e de compostos fenólicos como o ácido hidroxicinâmico (Morreel et al., 2004).

Também foi observado um acúmulo de transcritos codificando uma proteína de choque térmico (SCESMY2004C08) 1,6 vezes maior em raízes micorrizadas cultivadas em baixo P de que em controles não-micorrizados.

Foi observado também acúmulo de transcritos codificando uma peroxidase (SCESMY2008A10) em raízes de cana-de-açúcar colonizadas por G. clarum e cultivadas em condições de baixo P. Este acúmulo de transcritos foi 1,4 vezes maior em relação aos controles não-inoculados cultivados em baixo $\mathrm{P}$, e 1,9 vezes maior em relação a raízes micorrizadas cultivadas em condições de alto P. Em raízes de feijão cultivadas durante 8 semanas, atividades de peroxidases foram suprimidas pela colonização micorrízica em condições de baixo P, mas não foram alteradas em condições de alto P (Lambais et al., 2003).

O acúmulo de transcritos codificando uma peroxidase de ascorbato (APX, SCESMY2004H11) nos controles não-inoculados foi maior em relação às raízes micorrizadas e cultivadas em condições de baixo P (2,3 vezes) e alto $\mathrm{P}$ (1,3 vezes). Em raízes de fumo inoculadas com $G$. mosseae observa-se a indução pela colonização pelo fungo durante os 5 primeiros dias após a inoculação com posterior a supressão da APX (Blilou et al., 2000).

Outra proteína envolvida em reações de oxi-redução da célula é a tiorredoxina que é uma proteína pequena que reduz/oxida proteínas alvo (Powis \& Montfort, 2001). O maior acúmulo de 
transcritos codificando uma tiorredoxina H (SCESMY1003F09) ocorreu em raízes cultivadas em condições de alto P. Os controles não-inoculados cultivados em alto P apresentaram 2,6 vezes mais transcritos codificando tioredoxina $\mathrm{H}$ do que raízes micorrizadas cultivadas em condições de baixo P. O maior acúmulo de transcritos que codificam tiorredoxina $\mathrm{H}$ ocorreu em raízes colonizadas por $G$. clarum e cultivadas em condições de alto P, este acúmulo foi 8,1 vezes maior do que em raízes colonizadas e cultivadas em condições de baixo P e 23,1 vezes maior do que em controles não-inoculados cultivados em alto P. Tiorredoxinas H podem assegurar a persistência de atividades anti-oxidantes pela ativação de peroxidases dependentes de tiorredoxinas (Verdoucq et al., 1999). No fungo ectomicorrízico Tuber borchii, foi observado o acúmulo de transcritos codificando tiorredoxina em condições de deficiência de nutrientes ou durante a diferenciação celular (Lacourt et al., 2002). A indução de tiorredoxinas pode ser uma forma indireta de ativar as respostas anti-oxidantes em condições de estresse.

Outra proteína ligada a oxirredução que apresentou acúmulo diferencial de transcritos foi citocromo B5 (SCESMY2005H12) que é induzido em raízes colonizadas e cultivadas em alto P (3,8 vezes) em relação aos controles não-inoculados cultivados na mesma dose de $\mathrm{P}$.

\subsubsection{Genes relacionados à formação de parede celular e membranas}

A colonização das raízes pelos fungos micorrízicos arbusculares é acompanhada pela reorganização da parede celular e de outras matrizes extracelulares durante (1) a penetração na epiderme após a formação do apressório, (2) crescimento inter- e intrarradicular no córtex da raiz e (3) a diferenciação das estruturas da membrana e da parede celular ao redor dos arbúsculos.

No macroarranjo de cDNAs utilizado nesse experimento foram testados dois cDNAs codificando $\beta$-1,3-glucanases (SCESMY4002A02 e SCESMY2004G03). O acúmulo de transcritos do clone SCESMY4002A02 não variou entre os tratamentos. Mas, o acúmulo de transcritos do clone SCESMY2004G03 em raízes colonizadas por G. clarum cultivadas em condições de alto $\mathrm{P}$ foi aproximadamente 307 vezes maior do que em raízes colonizadas e cultivadas em condições de baixo P, e aproximadamente 127 vezes maior do que nos controles não-inoculados cultivados em condições de alto P. Algumas isoformas de $\beta$-1,3-glucanases vegetais podem atuar na degradação da parede celular de fungos fitopatogênicos (Mauch et al., 1988). Em raízes de cana-de-açúcar colonizadas por fungos micorrízicos arbusculares e cultivadas em condições de alto $\mathrm{P}$, indução de uma isoforma de $\beta$-1,3-glucanases poderia fazer 
parte do sistema de controle da micorrização pela planta, através da degradação da parede celular do fungo (Lambais \& Mehdy, 1995).

Durante o processo de colonização, a parede celular pode sofrer alterações pontuais pela incorporação de proteínas estruturais glicosiladas (van Buuren et al., 1999). Neste experimento, foram encontradas uma extensina (SCESMY3004F06) e uma arabinogalactana (SCESMY1002F05) envolvidas com o processo de glicosilação das proteínas da parede celular vegetal, apresentaram acúmulo diferencial significativo $(\mathrm{p}<0,05)$ de transcritos devido a colonização por FMAs.

Extensinas têm função similar a proteínas ricas em hidroxiprolina sendo ativadas em plantas sob condições de estresse físico (injúrias) e atuando no enrijecimento da parede celular (Ringli et al., 2005). Em condições de baixo P, o acúmulo de transcritos codificando uma extensina (SCESMY3004F06) foi 2,3 vezes maior em raízes micorrizadas cultivadas em condições de baixo P do que em controles não-inoculados. Níveis de indução similares (2 vezes) foram observados em raízes de Medicago truncatula inoculadas com $G$. mosseae e $G$. intraradices, em relação aos controles não-inoculados (Hohnjec et al., 2005).

Já, arabinogalactanas são proteínas que pertencem à família de glicoproteínas ricas em hidroxiprolina (Showalter, 2001). O acúmulo de transcritos codificando arabinogalactanas foi 2,4 vezes maior em raízes micorrizadas e cultivadas em alto $\mathrm{P}$ do que em raízes micorrizadas cultivadas em baixo P. Os controles não-inoculados não apresentaram alteração no acúmulo de transcritos codificando arabinogalactanas.

\subsubsection{Genes associados ao metabolismo de proteínas}

Dentre os genes relacionados com a síntese protéica, foram encontradas alterações significativas no acúmulo de transcritos codificando proteínas similares a 4 proteínas ribossomais.

Os transcritos codificando as proteínas ribossomais S9 (SCESMY2005E11) e S13 (SCESMY2008A04) da subunidade menor do ribossomo apresentaram, respectivamente, acúmulo 1,3 e 1,6 vezes maior em raízes micorrizadas cultivadas em condições de baixo P do que os controles não-inoculados cultivados na mesma condição de P.

Os transcritos codificando a proteína ribossomal S16 da subunidade menor do ribossomo (SCESMY2001F10) teve acúmulo induzido pela colonização micorrízica. Em raízes 
micorrizadas cultivadas em condições de baixo P, este acúmulo foi 2 e 2,5 vezes maior do que nos controles cultivados em condições de baixo e alto P, respectivamente. Em raízes colonizadas cultivadas em condições de alto P, o acúmulo de seus transcritos foi 1,8 vezes maior do que nos controles não-inoculados cultivados em alto P.

Os transcritos que codificam a proteína ribossomal S23 da subunidade menor do ribossomo (SCESMY2005C06) tiveram seu acúmulo induzido 2,4 vezes nos controles não-inoculados cultivados em alto $\mathrm{P}$ em relação às raízes colonizadas por G. clarum cultivadas na mesma condição de P.

Transcritos codificando uma proteína similar ao fator de iniciação de transcrição eIF6 (SCESMY2008A09) apresentaram acúmulo diferencial em função da concentração de P aplicada e da inoculação pelo fungo micorrízico. Em raízes colonizadas por G. clarum e cultivadas em baixo P, o acúmulo de transcritos codificando o eIF6 foi 1,3 e 1,7 vezes maior do que nos controles não-inoculados e nas raízes micorrizadas cultivadas em alto $\mathrm{P}$, respectivamente. As raízes não-colonizadas, o acúmulo de transcritos codificando o eIF6 foi 1,9 vezes maior em plantas cultivadas em alto P do que em plantas cultivadas em condições de baixo P.

Dentre os genes codificando proteínas associadas ao processamento de proteínas, uma carboxipeptidase de membrana (SCESMY2009F07) e uma protease específica de ubiquitina (SCESMY2001B06) apresentaram expressão diferencial significativa em raízes micorrizadas nas duas doses de $\mathrm{P}$ avaliadas. Os transcritos codificando uma carboxipeptidase de membrana apresentaram acúmulos 3,4 e 4,2 vezes maior nas raízes micorrizadas cultivadas em baixo e alto $\mathrm{P}$, respectivamente, do que nos controles não-inoculados cultivados na mesma dose de P.

Os transcritos codificando uma proteína similar a protease específica de ubiquitina apresentaram acúmulos de 1,7 e 6,2 vezes maior nas raízes micorrizadas cultivadas em baixo e alto $\mathrm{P}$, respectivamente, do que nos controles não-inoculados cultivados na mesma dose de P. Foi observado em raízes de A. thaliana associadas ao fungo Piriformospora indica, mimetizando uma associação micorrízica, que essas proteínas iniciam sua modulação anteriormente ao contato físico entre as raízes e o fungo, e que essa modulação não ocorre em mutantes insensíveis a $P$. indica. Isto indica que o processo de reconhecimento do fungo já desencadeia alterações nas células hospedeiras, mesmo antes do contato físico entre os organismos, através da percepção de moléculas sinais específicos (Oelmuller et al., 2005). 
O acúmulo de transcritos codificando uma aspartato proteinase (SCESMY2005D02) foi suprimido nos controles não-inoculados cultivados em condições de baixo P, cerca de 1,5 vezes em relação às raízes micorrizadas cultivadas em condições baixo $\mathrm{P}$ e cerca de 10,3 vezes em relação aos controles não-inoculados cultivados em baixo P. Em condições de alto $\mathrm{P}$, as raízes micorrizadas apresentaram supressão de 1,7 vezes no acúmulo de transcritos codificando essa protease, em relação aos controles não-micorrizados.

O acúmulo de transcritos codificando uma proteinase-cisteína (SCESMY2003D04) foi induzido 1,4 vezes pela colonização micorrízica em condições de baixo $\mathrm{P}$ em relação ao respectivo controle não-inoculado. Em Lotus japonicum, uma proteinase-cisteína foi induzida tanto em raízes micorrizadas quanto em raízes noduladas, 8 dias após a inoculação (Kistner et al., 2005). Em nódulos de Astragalus sinicus, proteinase de cisteína encontrada têm papel importante na ciclagem de compostos nitrogenados durante o processo de senescência do nódulo (Naito et al., 2000). Em M. truncatula, protease de cisteína é expressa em nódulos e raízes micorrizadas senescentes, sugerindo que os processos celulares associados à senescência do arbúsculo e dos nódulos sejam comuns às duas simbioses (Liu et al., 2003).

\subsubsection{Genes codificando componentes das vias de transdução de sinais}

Em leguminosas, diversos genes tidos como essenciais para o estabelecimento de simbioses foram identificados. Estes genes estão relacionados com os eventos de transdução de sinal ocorridos durante a formação do nódulo ou da MA.

Um gene com alta similaridade a um receptor tipo quinase de proteína (SCESMY2004G07) foi induzido 1,7 vezes em raízes colonizadas por G. clarum cultivadas em condições de alto P em relação aos controles não-inoculados cultivados na mesma dose.

Duas quinases de proteínas do tipo serina/treonina apresentaram expressão diferencial significativa nos experimentos de hibridização em macroarranjos. Os transcritos similares à EST SCESMY2008E04 tiveram seu acúmulo suprimido 2,4 vezes em raízes colonizadas cultivadas em condições de alto $\mathrm{P}$, em relação aos controles não-inoculados cultivados na mesma dose de $\mathrm{P}$. Os transcritos similares a segunda isoforma (SCESMY1001E06) apresentou comportamento distinto, tendo seu acúmulo suprimido 3,6 vezes em raízes colonizadas cultivadas em baixo P em relação aos controles não-inoculados cultivados em condições de alto P. 
Os transcritos codificando uma quinase de proteína (SCESMY1001E01) tiveram seu acúmulo suprimido 2,3 vezes em raízes micorrizadas cultivadas em condições de baixo P, em relação aos respectivos controles não-inoculados. Já, em condições de alto $P$, em raízes micorrizadas, o acúmulo de seus transcritos foi 7 vezes maior do que nos controles nãoinoculados.

Os transcritos codificando uma quinase de proteína ativada pelo mitógeno (MAP kinase) (SCESMY4001B07) apresentam acúmulo induzido 6,6 vezes nos controles não-inoculados cultivados em condições de alto P em relação aos controles cultivados em condições de baixo P. Em condições de alto P, o acúmulo de transcritos foi suprimido 2,1 vezes em raízes micorrizadas em relação aos controles não-inoculados. Estas quinases de proteínas poderiam atuar a jusante na cascata de transdução de sinais facilitando a amplificação do sinal durante a interação micorrízica (Hohnjec et al., 2005), e podendo desencadear processos como mitose, diferenciação e a morte celular programada.

Vários trabalhos têm relatado que plantas com maior teor de P em seus tecidos apresentam maior tolerância à infecção por patógenos ou FMAs (Brenner, 2000; Lambais et al, 2003). Esta maior tolerância poderia estar relacionada com a indução de quinases de proteínas demonstrada neste experimento. Supõem-se que a fertilização fosfatada poderia aumentar o número de cópias de quinases de proteínas (aumentando a fosforilação) tornando a cascata de sinais mais intensa, culminando com uma resposta de defesa mais forte.

Os transcritos codificando uma calmodulina (SCESMY3007F07) tiveram seu acúmulo induzido 3,7 vezes em raízes colonizadas cultivadas em condições de alto P em relação aos controles não-inoculados cultivados na mesma dose.. Em leguminosas, já foi identificado que uma quinase de proteína dependente de calmodulina é essencial para o estabelecimento de ambas as simbioses (Cullimore \& Dénarié, 2003).

Ainda relacionado à transdução de sinais, foram observados dois transcritos codificando proteínas com função desconhecida, que poderiam estar relacionadas com a sinalização intracelular (SCESMY3005A09 e SCESMY2003G02). Transcritos similares a SCESMY3005A09 tiveram seu acúmulo suprimido 1,9 vezes em raízes micorrizadas, em relação aos controles não-inoculados e cultivados em ambas as doses de P. Estas proteínas com função desconhecida podem ser essenciais para o estabelecimento da simbiose em cana-de-açúcar pois 
até o presente momento, os genes essenciais para o estabelecimento da simbiose descobertos em leguminosas estavam relacionados com a transdução de sinais.

\subsubsection{Genes indicadores do processo de colonização intrarradicular}

Este trabalho também tentou identificar genes que possam ser utilizados como marcadores do processo de colonização intrarradicular por FMAs. Em M. truncatula, diversos genes já foram identificados, inclusive um transportador de fosfato (MtPt4) identificado por Harrison et al. (2002), sendo que a presença de transcritos codificando este gene foi utilizada por Hohnjec et al. (2005) como critério para selecionar as raízes que seriam utilizadas para a hibridização em microarranjos. Foi observado acúmulo de transcritos codificando um transportador de fosfato tipo ABC (SCESMY1003C02) foi induzido 25,8 vezes em raízes micorrizadas cultivadas em condições de alto $\mathrm{P}$, em relação aos controles não-inoculados cultivados na mesma dose de P. Este transportador de fosfato tipo ABC pode ser um candidato a marcador da colonização em raízes de cana-de-açúcar.

Doll et al. (2003) caracterizaram uma proteína similar a germina (MtGlp1) que apresenta expressão induzida apenas em raízes micorrizadas. Outro trabalho, caracterizou uma glutationeS-transferase com expressão também induzida unicamente em raízes micorrizadas (Wulf et al., 2003). Neste trabalho, foram encontradas uma proteína similar a germina (SCESMY2003B05) e uma glutatione-transferase III (SCESMY2003B10) induzidas 2,1 e 1,9 vezes, respectivamente, apenas em raízes colonizadas cultivadas em condições de baixo $\mathrm{P}$, em relação aos controles nãoinoculados cultivados na mesma dose de P.

Um gene similar a uma carboxipeptidase de membrana (SCESMY2009F07) foi induzido em raízes micorrizadas cultivadas nas duas doses de P. Este gene também seria um candidato a marcador, já que o acúmulo de seus transcritos foi 4 vezes maior nas raízes micorrizadas do que nos controles não-inoculados, serina carboxipeptidase (MtScp1) foi utilizada como indicador de micorrização (Liu et al. 2003).

\subsubsection{Possíveis mecanismos de regulação gênica durante o desenvolvimento de MAs}

A partir da análise do transcritoma de raízes de cana-de-açúcar colonizadas por G. clarum, através de hibridização em macroarranjos, foi constatado que vários genes envolvidos em 
transdução de sinais, respostas de defesa e estresse apresentam expressão diferencial, e que é possível que esses genes sejam essenciais para o controle da simbiose.

É provável que as plantas possuam genes codificando receptores envolvidos no reconhecimento de moléculas sinais sintetizadas pelos FMAs, muito embora, esses genes não tenham sido identificados até o presente. Em nossos experimentos, um gene codificando um receptor do tipo kinase de proteínas (SCESMY2004G07) apresentou expressão induzida em raízes micorrizadas em condições de alto $\mathrm{P}$, em relação ao controle não-inoculado, sugerindo que esse gene possa codificar um receptor para moléculas sinais sintetizadas pelos FMAs nessas condições. Provavelmente, em condições de baixo P, um outro receptor seria essencial para o reconhecimento de moléculas sinais de origem fúngica, já que esse gene não apresentou alteração de expressão significativa em raízes micorrizadas em condições de baixo P, em relação ao controle não-inoculado.

Em raízes micorrizadas em condições de alto $\mathrm{P}$, foi observado também que um gene codificando um precursor de uma $\mathrm{H}^{+}$-ATPase tipo 2 (SCESMY2009E05) apresentou expressão significativamente maior do que no controle não-inoculado, sugerindo que alterações do fluxo de prótons podem ocorrer em MAs. De fato, alterações nas atividades de $\mathrm{H}^{+}$-ATPases e no fluxo de $\mathrm{H}^{+}$em MAs já foram descritos por Ramos et al. (2005).

Essas alterações no fluxo de íons poderiam alterar a atividade de quinases de proteínas, as quais são normalmente recrutadas na transdução de sinais em várias interações plantamicrorganismos (McDowell \& Dangl, 2000). Em raízes de cana-de-açúcar micorrizadas em condições de alto $\mathrm{P}$, a expressão de genes codificando uma quinase de proteínas dependente de $\mathrm{Ca}^{+2}$ (SCESMY4001B07), quinases de histidina (SCMY4002E05) e serina-treonina de proteína (SCESMY2001E06) foi induzida, sugerindo que a fosforilação de proteínas é um evento importante na transdução de sinais moleculares em MAs.

Outro mecanismo de regulação da expressão gênica em MAs pode ser através do controle da concentração de espécies ativas de oxigênio nas células (Lambais et al., 2003). Em nossos experimentos foi observado que a expressão de um gene codificando catalase é altamente induzida em raízes micorrizadas em condições de alto $\mathrm{P}$, em relação a raízes micorrizadas em condições de baixo P, concordando com os dados obtidos de Lambais et al. (2003) avaliando a atividade de catalases em raízes de feijão colonizadas por Glomus intraradices. Os dados sugerem ainda que a regulação de catalases em MAs ocorre no nível de transcrição. Outros genes 
codificando enzimas envolvidas na degradação de espécies ativas de oxigênio, como peroxidades, glutatione transferase (SCESMY3008B10) também apresentaram expressão induzida em MAs, enquanto a expressão de um gene codificando uma ascorbato peroxidase citossólica (SCESMY2004H10) é suprimida, sugerindo que a regulação diferencial de genes codificando enzimas envolvidas no metabolismo de espécies ativas de oxigênio pode ser um fator determinante no estabelecimento da simbiose.

Observou-se também que em raízes micorrizadas a expressão de um gene codificando uma b-1,3-glucanases (SCESMY2004G03) é induzida em raízes micorrizadas em condições de alto P. Outros genes associados ao metabolismo de parede celular vegetal, como cafeoil-CoA Ometiltransferase (SCESMS1002C04), cinamoil-CoA redutase (SCESMY2001D11) são induzidos em raízes micorrizadas, sugerindo que alterações na parede celular também são importantes para a formação de MAs.

Outro processo que parece ser importante para a formação de MAs é a degradação de proteínas. Várias proteases (SCESMY2001B06, SCESMY2005D02, SCESMY2004E01) apresentaram expressão diferencial em raízes micorrizadas, em relação ao controle não-micorrizado. Particularmente, o gene codificando um precursor de protease aspártica (SCESMY2005D02) é particularmente interessante. Esse gene apresentou expressão induzida em raízes micorrizadas em condições de baixo P, e expressão suprimida em condições de alto $\mathrm{P}$, em relação ao controle não-micorrizado. Esses dados sugerem que essas proteases podem ser essenciais para o crescimento fúngico intrarradicular, pois o fungo patogênico Botrix cineria secreta grandes quantidades de proteínase aspártica e esta pode ter papel essencial no processo de infecção (Have et al. 2004).

Observou-se também que transcritos codificando nitrilase não são acumulados em raízes micorrizadas cultivadas em alto $\mathrm{P}$, mas têm o seu acúmulo induzido em raízes micorrizadas cultivadas em baixo P. Nitrilases estão envolvidas na síntese de auxinas, principalmente AIA (ácido indol acético) e mesmo não sendo conhecido o papel do AIA na simbiose, especula-se que este tem efeito na morfologia da raiz e no crescimento da hifa extrarradicular dos FMAs, devido ao acúmulo de AIA no solo que são exsudados das raízes de plantas (Gryndler et al., 1998).

As alterações dos perfis de acúmulo em raízes de cana-de-açúcar cultivadas em diferentes condições, demonstra que a simbiose micorrízica é um processo complexo e que requer diversas alterações da fisiologia do hospedeiro para a sua funcionalidade. 


\section{CONCLUSÕES}

- A construção de biblioteca subtrativa mostrou-se pouco eficiente para a identificação de genes diferencialmente expressos em raízes de cana-de-açúcar colonizadas por fungos micorrízicos arbusculares.

- A construção de bibliotecas de ESTs mostrou-se uma técnica poderosa para a identificação de novos transcritos expressos exclusivamente em raízes micorrizadas, sendo que mais de 40\% destas ESTs não foram encontradas no banco SUCEST.

- O acúmulo de transcritos de genes relacionados à transdução de sinais em raízes de canade-açúcar micorrizadas em alto P, pode indicar a ocorrência de uma transdução de sinais mais intensa nestas condições.

- Foi observado que o acúmulo de transcritos codificando proteínases podem ser essenciais para a colonização das raízes pelo fungo micorrízico arbuscular.

- A caracterização dos genes que apresentaram acúmulo diferencial de transcritos em raízes micorrizadas poderá contribuir para a elucidação dos mecanismos genéticos envolvidos no controle da simbiose. 


\section{REFERÊNCIAS}

ALEXANDER, T.; MEIER, R.; TOTH, R.; WEBER, H.C. Dynamics of arbuscules development and degeneration in mycorrhizas of Triticum aestivum L. and Avena sativa L.with reference to Zea mays L. New Phytologist, New York, v. 110, n. 3, p. 363-370, 1988.

ALEXANDER, T.; TOTH, R.; MEIER, R.; WEBER, H.C. Dynamics of arbuscule developmente and degeneration in onion, bean and tomato with reference to vesicular arbuscular mycorrhizae in grasses. Canadian Journal of Botany, Ottawa, v. 67, n. 8, p. 2505-2513, 1989.

ALLEN, M.F.; ALLEN, E.B.; FRIESE, C.F. Response of the non-mycotrophic plant Salsola kali to invasion by vesicular-arbuscular mycorrhizal fungi. New Phytologist, New York, v.111, n. 1, p. 45-49, jan. 1989.

ANDREOLA, F. Micorriza VA em cana-de-açúcar. 1982. 74 p. Dissertação (Mestrado em Microbiologia Agrícola) - Escola Superior de Agricultura “Luiz de Queiróz”, Universidade de São Paulo, Piracicaba, 1982.

ARRUDA, P. Sugarcane transcriptome. A landmark in plant genomics in the tropics. Genetics and Molecular Biology, Ribeirão Preto, v.24, n. 1/4, p.1-3, 2001.

BÉCARD, G., DOUDS, D.D., PFEFFER, P.E. Extensive in vitro hyphal growth of vesiculararbuscular mycorrhizal fungi in thepresence of $\mathrm{CO}_{2}$ and flavols. Applied and Environmental Microbiology, Washington, v.58, n.3, p. 821-825, 1992.

BÉCARD, G.; TAYLOR, L.P.; DOUDS, D.D.; PFEFFER, P.E; DONER, L.W. Flavonoids are not necessary plant signal compounds in arbuscular mycorrhizal simbiosis. Molecular PlantMicrobe Interactions, St. Paul, v.8, n.2, p. 252-258, 1995.

BODKER, L.; KJOLLER, R.; ROSENDAHL, S. Effect of phosphate and the arbuscular mycorrhizal fungus Glomus intraradices on disease severity of root rot of peas (Pisum sativum) causade by Aphanomyces euteiches. Mycorrhiza, Berlin, v.8, n.3, p. 169-174, 1998.

BOLAN, N.S. A critical review on the role of mycorrhizal fungi in the uptake of phosphorus by plants. Plant and Soil, Dordrecht, v. 134, n. 1, p. 189-207, 1991.

BOLLER, T. Hydrolytic enzymes in plant disease resistance. In: KOSHUGE, T.; NESTER, E.W. (Ed.) Plant-microbe interactions, molecular and genetic perspectives. New York: Macmillan, 1987. chap. 7, p. 358-411.

BOLLER, T. Ethylene and regulation of antifungal hydrolases in plants. In: MIFLIN B.J. (Ed.) Surveys of plant molecular and cell biology. Oxford: Oxford University Press, 1988. chap. 4, p. $145-174$.

BOLLER, T.; GEHRI, A.; MAUCH, F. et al. Chitinase in bean leaves: Induction by ethylene, purification, properties, and possible function. Planta, New York,v. 157, n.1, p. 22-31, 1983. 
BONFANTE-FASOLO, P. Anatomy and morphology of VA mycorrhizae. In: POWELL, C.L.; BAGYARAJ, D.J. (Ed.). VA Mycorrhizae. Boca Raton, FL: CRC Press, 1984. chap. 1, p. 5-33.

BONFANTE-FASOLO, P.; PEROTTO, S. Strategies of mycorrhizal fungi when infecting host plants. New Phytologist, New York, v.119, n.1, p. 115-120, 1991.

BONFANTE-FASOLO, P.; PEROTTO, S. Plant and endomycorrhizal fungi: the celular and molecular basis of their interaction. In: VERMA, D.P.S. (Ed.) Molecular signals in plantmicrobe communications. Boca Raton, FL: CRC Press, 1992. chap. 14, p. 445-470.

BONFANTE-FASOLO, P.; PEROTTO, S. Strategies of mycorrhizal fungi when infecting host plants. New Phytologist, New York, v.130, n.1, p. 3-21, 1995.

BOWTEL, D.; SAMBROOK, J. DNA Microarrays: a molecular cloning manual. New York. Cold Spring Harbor Laboratory press, 2003. 712 p.

BRAUN, D.M.; WALKER, J.C. Plant transmembrane receptors: New pieces in the signaling puzzle. Trends in biochemical Sciences, Oxford, UK, v.21, n.2, p.70-73, 1996.

BUCKING, H.; HEYSER, W. Uptake and transfer of nutrients in ectomycorrhizal associations between photosynthesis and phosphate nutrition. Mycorrhiza, Berlin, v. 13, n. 2, p. 59-68, 2003.

CARDOSO, E.J.B.N.; LAMBAIS, M.R. Aplicações práticas de micorrizas vesículo-arbusculares (MVA). In: CARDOSO, E.J.B.N.; TSAI, S.M.; NEVES, M.C.P. (Ed.). Microbiologia do Solo. Campinas: Sociedade Brasileira de Ciência do Solo, 1992. cap. 18, p. 283-296.

CARNEIRO, N.P.; HUGHES, P.A.; LARKINS, B.A. The eEFIA gene family is differentially expressed in maize endosperm. Plant Molecular Biology, Dordrecht, v.41, n.6, p.801-813, 1999.

COLEBATCH, G.; TREVASKIS, B.; UDVARDI, M. Functional genomics: tools of the trade. New Phytologist, New York, v.153, n.1, p.27-36, 2002.

COLLINGE, D.B.; KRAGH, K.M.; MIKKELSEN, L.D.; NIELSEN, K.K.; RASMUSSEN, U.; VAD, K. Plant chitinases. Plant Journal, Oxford, UK, v.3, n.1, p.31-40, 1993.

CULLIMORE, J.; DENARIE, J. How legumes select their sweet talking symbionts. Science, New York, v.302, n.5645, p.575, 2003.

DAINESE, M.B.; CARDOSO, E.J.B.N. Algumas observações sobre fungos micorrízicos em associação com a cana-de-açúcar em Piracicaba. O Solo, Piracicaba, v.73, n.1, p.24-27, 1981.

DAVID, R.; ITZHAKI, H.; GINZBERG, I. et al. Supression of tobacco basic chitinase gene expression in response to colonization by the arbuscular mycorrhizal fungus Glomus intraradices. Molecular Plant-Microbe Interactions, St. Paul, v.11, n.3, p. 489-497, 1998. 
DITT, R.F.; LAMBAIS, M.R. Genes codificando proteínas acessórias da urease (UreG) são induzidos em raízes de fumo infectadas por Glomus intraradices. In: CONGRESSO BRASILEIRO DE MICROBIOLOGIA, 19., 1997 Rio de Janeiro. Resumos... Rio de Janeiro: Sociedade Brasileira de Microbiologia, 1997. p.213.

DIATCHENKO, L.; LAU, Y.F.C.; CAMPBELL, A.P. et al. Supressive subtractive hybridization: A method for generating differentially regulated or tissue-specific cDNA probes and libraries. Proceedings of the National Academy of Sciences of the United States of America, New York, v.93, n.12, p.6025-6030, 1996.

DIXON, R.A.; HARRISON, M.J. Activation, structure and organization of genes involved in microbial defense in plants. Advances in Genetics, New York,v. 28, n. 1, p. 165-234, 1990.

DOUDS, D.D.; NAGAHASHI, G.; ABNEY, G.D. The differencial effects of cell wallassociated phenolics, cell wall, and cytosolic phenolics of host and non-host roots and the growth of two species of AM fungi. New Phytologist, New York, v.133, n.2, p. 289-294, 1996.

DUC, G.; TROUVELOT, A.; GIANINAZZI-PEARSON, V.et al. First report of nonmycorrhizal mutantes (myc-) obtained in pea (Pisum sativum L.) and faba bean (Vicia faba L.). Plant Science, Clare, v. 60, n. 2, p. 215-222, 1989.

DURSO, N.A.; CYR, R.J. Beyond translation - Elongation factor-1-alpha and the cytoskeleton. Protoplasma, Viena, v.180, n.3/4, p.99-105, 1994.

EISEN, M.B.; SPELLMAN, P.T.; BROWN, P.O.; BOTSTEIN, D. Cluster analysis and display of genome-wide expression patterns. Proccedings of the National Academy of Sciences of the United States of America, New York, v.95, n.25, p. 14863-14868, 1998.

ENDO, M.; HAKOZAKI, H.; KOKUBUN, T. et al. Generation of 919 expressed tags from immature flower buds and gene expression analysis using expressed sequence tags in the model plant Lotus japonicus. Genes and Genetic Systems, Mishima, v.77, n.4, p.277-282, 2002.

EWING, B.; GREEN, P. Base-calling automated sequencer traces using phred. II Erros probabilities. Genome Research, Woodbury, v.8, n.3, p.186-194, 1998.

EZETA, F.N.; SANTO, O.M. Benefício da introdução de endomicorriza eficiente na utilização de nutrientes em solos do sul da Bahia. Revista Brasileira de Ciência do Solo, Campinas, v.9, p. 13-17, 1980.

FANTIL, W.J.; JOHNSON, D.E.; WILLIAMS, L.T. Signalling by receptor tyrosine kinases. Annual Review of Biochemistry, Palo Alto, v. 62, n.3, p. 453-481, 1993.

FEDOROVA, O.; SU, J.L.; PYLE, A.M. Group II introns: higky specific endonucleases with modular structures and diverse catalytic functions. Methods, San Diego, v.28, n.3, p.323-335, 2002. 
FIGUEIRA, A.; KIDO, E.A.; ALMEIDA, R.S. Identifying sugarcane expressed sequences associated with nutrient transporters and peptide metal chelators. Genetics and Molecular Biology, v.24, n.1-4, p.207-220, 2001.

GARCIA-GARRIDO, J.M.; CABELLO, M.N.; GARCÍA-ROMERA, I. Endoglucanase activy in lettuce plants colonized with the vesicular-arbuscular mycorrhizal fungus Glomus fasciculatum. Soil Biology and Biochemistry, Oxford, v.24, n.10, p. 955-959, 1992a.

GARCIA-GARRIDO, J.M.; GARCIA-ROMERA, I.; OCAMPO, J.A. Cellulase production by the vesicular-arbuscular mycorrhizal fungus Glomus mosseae (Nicol. \& Gerd.) Gerd. \& Trappe. New Phytologist, New York, v. 121, n. 2, p. 221-226, $1992 b$.

GINZBERG, I.; DAVID, R.; SHAUL, O. et al. Glomus intraradices colonization regulates gene expression in tobacco roots. Symbiosis, Rehovot, v.25, n.1/3, p. 145-157, 1998.

GIOVANNETTI, M.; MOSSE, B. An evaluation of techniques for measuring vesiculararbuscular mycorrhizal infection in roots. New phytologist, New York, v.84, n.3, p. 489-500, 1980.

GIOVANETTI, M.; AVIO, L.; SBRANA, C.; et al. Factors affecting appressorium development in the vesicular-arbuscular mycorrhizal fungus Glomus mosseae (Nicol. \& Gerd.) Gerd \& Trappe. New Phytologist, New York, v. 123, n. 1, p. 115-122, 1993.

GURSKAYA, N.G.; DIATCHENKO, L.; CHENCHIK, A. et al. Equalizing cDNA subtraction based on selective supression of polymerase chain reaction: Cloning of Jurkat cell trnascripts induced by phytohemaglutinin and phorbol 12-myristate 13-acetate. Analytical Biochemistry, San Diego, v.240, n.1, p.90-97, 1996.

GYORGYEY, J.; VAUBERT, D.; JIMENEZ-ZURDO, J.I. et al. Analysis of Medicago truncatula nodule expressed sequence tags. Molecular Plant-Microbe Interactions, St. Paul, v. 13, n. 1, p. 62-71, 2000.

HANDBERG, K.; STOUGAARD, J. Lotus japonicus, an autogamous, diploid legume species for classical and molecular genetics. Plant Journal, Oxford (UK), v.2, n.4, p.487-496, 1992.

HARLEY, J.L.; SMITH, S.E. Mycorrhizal symbiosis. London, New York: Academic Press, 1983. 786p.

HARRIER, L.A.; WRIGTH, F.; HOOKER, J.E. Isolation of the 3-phosphoglycerate kinase gene of the arbuscular mycorrhizal fungus Glomus mossae. Current Genetics, Berlin, v. 34, n.3, p.386-392, 1998.

HARRISON, M.J. A sugar transporter from Medicago truncatula: altered expression pattern in roots during vesicular-arbuscular (VA) mycorrjizal associations. Plant Journal, Oxford, UK, v. 9, n. 3, p. 491-503, 1996. 
HARRISON, M.J. Molecular and celular aspects of arbuscular mycorrhizas. Annual Review of Plant Physiology and Plant molecular Biology, Stanford, v.50, n.1, p. 361-389, 1999.

HARRISON, M.J.; DIXON, R.A. Isoflavonoid accumulation and expression of defense gene transcripts during the establishment of vesicular-arbuscular mycorrhizal associations in roots of Medicago truncatula. Molecular Plant-Microbe Interactions, New York, v.6, n. 5, p.643-654, 1993.

HARRISON, M.J.; van BUUREN, M.L. Aphosphate transporter from the mycorrhizal fungus Glomus versiforme. Nature, London, v. 378, n. 5, p. 626-629, 1995.

HOHNJEC, N.; PERLICK, A.M.; PUHLER, A. et al. The Medicago truncatula sucrose synthase gene MtSucS1 is activated both in the infected region of root nodules and in the cortex of roots colonized by arbuscular mycorrizal fungi. Molecular Plant-Microbe Interactions, St. Paul, v.16, n.10, p.903-915, 2003.

HOHNJEC, N.; VIEWEG, M.F.; PÜHLER, A.; BECKER, A.; KÜSTER, H. Overlaps in the transcriptional profiles of Medicago truncatula roots inoculated with two different Glomus fungi provide insights into the genetic program activated during arbuscular mycorrhiza. Plant Physiology, Rockville, v. 137, p. 1283-1301, 2005.

HUANG, X.Q.; MADAN, A. CAP3: A DNA sequence assembly program. Genome research, Woodbury, v. 9, n. 9, p. 868-877, 1999.

JAKOBY, M.; WEISSHAAR, B.; DROGE-LASER, W. et al. bZIP transcriptional factors in Arabidopsis. Trends in Plant Sciences, London, v.7, n.3, 106-111, 2002.

JOHNSON, C.; BODEN, E.; DESAI, M. et al. In vivo target promoter-binding activies of a xenobiotic stress-activated TGA factor. Plant Journal, Oxford (UK), v.28, n.2, p.237-243, 2001.

JORDA, L.; COEGO, A.; CONEJERO, V.;VERA, P. Genomic cluster containing four differentially regulated subtilisin-like processing protease genes is in tomato plants. Journal of Biological Chemistry, Bethesda, v.4, n.274, p.2360-2365, 1999.

JOURNET E.; van TUINEN, D.; GOUZY, J. ExplOring root symbiotic programs in the model legume Medicago truncatula EST analysis, Nucleic Acids Research, Oxford, v.30, n.24, p.55795592, 2002.

KHALIQ, A.; SANDERS, F.E. Effects of phodphorus application and vesicular arbuscular mycorrhizal inoculation on the growth and phosphorus nutrition of maize. Journal of Plant Nutrition, New York, v.20, n.11, p. 1607-1616, 1997.

KIM, S.; AHN, I.P.; LEE, Y.H. Analysis of genes expressed during rice - Magnaporthe grisea interactions. Molecular Plant-Microbe Interactions, St. Paul, v.14, n.11, p.1340-1346, 2001. 
KISTNER, C.; WINZER, T.; PITZSCHKE, A. et al. Seven Lotus japonicus genes required for transcriptional reprogramming of the root during fungal and bacterial symbiosis. Plant Cell, Rockville, v.17, n.8, p.2217-2229, 2005.

KOIDE, R.T.; LI, M. On host regulation of the vesicular-arbuscular mycorrhizal symbiosis. Annual Review of Plant Physiology and Plant Molecular Biology, Stanford, v. 43, n.1, p.557581, 1990.

KURAMAE, E.E.; FENILLE, R.C.; de ROSA, V.E. Identification of 14-3-3-like protein in sugarcane (Saccharum officinarum). Genetics and Molecular Biology, Ribeirão Preto, v.24, n.14, p.43-48, 2001.

LACOURT, I.; DUPLESSIS, S.; ABBA, S. et al Isolation and characterization of differentially expressed genes in the mycelium and fruit body of Tuber borchii. Applied and Environmental Microbiology, Washington, v.68, n.9, p.4574-4582, 2002.

LAMBAIS, M.R. Aspectos bioquímicos e moleculares da relação fungo-planta em micorrizas arbusculares. In: SIQUEIRA, J.O. Avanços em fundamentos e aplicação de micorrizas. Lavras, MG: UFLA - DCS, DCF, 1996. Cap. 2, p. 5-38.

LAMBAIS, M.R.; MEHDY, M.C. Supression of endochitinase, $\beta-1,3$-endoglucanase, and chalcone isomerase expression in bean vesicular-arbuscular mycorrhizal roots under different soil phosphate conditions. Molecular Plant-Microbe Interactions, St. Paul, v.6, n.1, p. 75-83, 1993.

LAMBAIS, M.R.; MEHDY, M.C. Differencial expression of defense-related genes in arbuscular mycorrhiza. Canadian Journal of Botany, Ottawa, v.73, n.4, p.533-540, 1995.

LAMBAIS, M.R.; MEHDY, M.C. Soybean roots infected by Glomus intraradices strains differing in infectivity exhibit differential chitinase and $\beta$-1,3-glucanase expression. New Phytologist, New York, v. 134, n. 3, p. 531-538, 1996.

LAMBAIS, M.R.; MEHDY, M.C. Spatial distribution of chitinases and $\beta$-1,3-endoglucanase transcripts in bea arbuscular mycorrhizal roots under low and high phosphate conditions. New Phytologist, New York, v.140, n.1, p. 33-42, 1998.

LAMBAIS, M.R.; RIOS-RUIZ, W.F.; ANDRADE, R.M. Antioxidant responses in bean (Phaseolus vulgaris) roots colonized by arbuscular mycorrhizal fungi. New Phytologist, New York, v. 160, n. 2, p. 421-428, 2003.

LANFRANCO, L.; BOLCHI, A.; ROS, E.C. et al. Differential expression of a metallothionein gene during the presymbiotic versus the symbiotic phase of an arbuscular mycorrhizal fungus. Plant Physiology, Rockville, v. 130, n. 1, p. 58-67, 2002.

LANGE, J.; XIE, Z.P.; BROUGHTON, W.J. et al. A gene encoding a receptor-like protein in the roots of common bean is differentially regulated in response to pathogens, symbionts and nodulation factors. Plant Science, Clare, v. 142, n. 1, p. 133-145, 1999. 
LIU, H.; THIEU, A.T.; BLAYLOCK, L.A. et al. Cloning and caracterization of two phosphate transporters from Medicago truncatula Roots: regulation in response to phosphate and to colonization by arbsucular mycorrhizal (AM) fungi. Molecular Plant-Microbe Interactions, St. Paul, v. 11, n. 1, p. 14-22, 1998.

LIU, J.Y.; BLAYLOCK, L.A.; ENDRE, G. et al. Transcript profiling coupled with spatial expression analyses reveals genes involved in distinct developmental stages of an arbuscular mycorrhizal symbiosis. Plant Cell, v.15, n.9, p.2016-2123, 2003.

MAGUIRE, T.L.; GRIMMOND, S.; FORREST, A. et al. Tissue-specific gene expression in soybean (Glycine max) detected by cDNA microarray analysis. Journal of Plant Physiology, Jena, v.159, n.12, p.1361-1374, 2002.

MANTHEY, K.; KAJINSKI, F.; HOHNJEC, N. Transcriptome profiling in root nodules and arbuscular mycorrhiza identifies a collection of new genes induced during Medicago truncatula root endosymbiosis. Molecular Plant-Microbe Interactions, St. Paul, v.17, n.10, p.1063-1077, 2004.

MARTIN-LAURENT, F.; van TUINEN, D.; DUMAS-GAUDOT, E. et al. Differential display analysis of RNA accumulation in arbuscular mycorrhiza of pea and isolation of a novel symbiosis-regulated plant gene. Molecular and General Genetics, Berlin, v. 256, n. 1, p. 37-44, 1997.

MAUCH, F.; MAUCHMANI, B.; BOLLER, T. Antifungal hydolases in pea tissue. 2. Inhibition of fungal growth by conbinations of chitinase and beta-1,3-glucanase. Plant Physiology, v.88, n.3, p.936-942, 1988.

MCPHERSON, J. Overgo Probing of High-Density Filters. Disponível em: $<$ http://www.tree.caltech.edu/protocols/overgo.html>. Acesso em: 10 jan. 2005.

MURPHY, P.J.; LANGRIDGE, P.; SMITH, S.E. Cloning plant genes sifferentially expressed during colonization of roots of Hordeum vulgaris by the vesicular-arbuscular mycorrhizal fungus Glomus intraradices. New Phytologist, New York, v. 135, n. 2, p. 291-301, 1997.

NAGAHASHI, G.; DOUDS, D.D. Apressorium formation by AM fungi on isolated cell walls of carrot roots. New Phytologist, New York, v. 136, n. 2, p. 299-304, 1997.

NAITO, Y.; FUJIE, M.; USAMI, S. et al. The involvement of a cysteine proteinase in the nodule development in Chinese milk vetch infected with Mesorhizobium huakuii sub. sp. rengei. Plant Physiology, Rockville, v. 124, n.3, p.1087-1095, 2000.

NOGUEIRA, A.V. As micorrizas e o excesso de metais. In: SIQUEIRA, J.O. (Ed.) Avanços em fundamentos e aplicações de micorrizas. Lavras: UFLA/DCS, DCF, 1996. cap. 13, p. 135174. 
NOGUEIRA, F.T.S; DE ROSA JÚNIOR, V.E.; MENOSSI, M. RNA expression profiles and data mining nof sugarcane responses to low temperature. Plant Physiology, Rockville, v.132, p.1811-1824, aug. 2003.

NOLTE, K.D.; HENDRIX, D.L.; RADIN, J.W. et al. Sucrose synthase localization during initiation of seed development and trichome differentiation in cotton ovules. Plant Physiology, v. 109, n.4, p.1285-1293, 1995.

OBA, H. et al. Arbuscular mycorrhizal fungal communities associated with some pioner plants in the Lahar área of Mt, Pinatubo, Philipines. Soil Science and Plant Nutrition, Tokyo, v.50, n.8, p.1195-1203, 2004.

OELMÜLLER, R.; PESKAN-BERGHÖFER, T.; Bationa SHAHOLLARI, B.; TREBICKA, A.; SHERAMETI; I.; VARMA, A. MATH domain proteins represent a novel protein family in Arabidopsis thaliana, and at least one member is modified in roots during the course of a plantmicrobe interaction. Physiologia Plantarum, Kobenhavn, v.124, p. 152-166, 2005.

PARK, D.S.; LANDINI, S.; GRAHAN, M.Y. et al. Induced distal defence potentiation against Phytophthora sojae in soybean. Physiological and Molecular Plant Pathology, Stanford, v.60, n.6, p.293-310, 2002.

PARRA-GARCIA, M.D.; LO-GIUDICE, V.; OCAMPO, J.A. Absence of VA colonization in Oxalis pescoprae inoculated with Glomus mosseae. Plant and Soil, Dordrecht, v. 145, n.2, p. 298-300, 1992.

POWIS, G.; MONTFORT, W.R. Properties and biological activities of thioredoxins. Annual Review of Pharmacology and Toxicology, New York, v.41, n.1, v.261-295, 2001.

RAMOS, A.C.; MARTINS, M.A.; FAÇANHA, A.R. Atividade atpásica e pirofosfática em microsomos de raízes de milho colonizadas por fungos micorrízicos arbusculares. Revista Brasileira de Ciência do Solo, Campinas, v.29, n.1, p.207-213, 2005.

REBRIKOV, D.V.; KOGAN, Y.N. The use of supressive subtractive hybridization to identify strain-specific sequences in bacterial genomes. Russian Journal of Genetics, Moscow, v.39, n.10, p.1112-1115, 2003.

REIS, V.M.; PAULA, M.A.; DÖBEREINER, J. Ocorrência de micorrizas arbusculares e da bactéria diazotrófica Acetobacter diazotrophicus em cana-de-açúcar. Pesquisa Agropecuária Brasileira, Brasilia, v.34, n.10, p.1933-1941, 1999.

RINGLI, C.; HAUF, G.; KELLER, B. Hydrophobic interactions of the structural protein GRP 1.8 in the cell wall of protoxylem elements. Plant Physiology, Rockville, v.125, n.2, p.673-682, 2001.

ROUSSEL, H.; BRUNS, S.; GIANINAZZI-PEARSON, V. et al. Induction of a membrane intrinsic protein-encoding mRNA in arbsucular mycorrhiza and elicitor-stimulated cell suspension cultures of parsley. Plant Science, Clare, v. 126, n.2, p.203-210, 1997. 
RUIZ-LOZANO, J.M.; ROUSSEL, H.; GIANINAZZI, S. et al. Defense genes are differentially induced by a mycorrhizal fungus and Rhizobium sp. in wild-type and symbiosis-defective pea genotypes. Molecular Plant-Microbe Interactions, St. Paul, v.13, n. 8, p. 976-984, 1999.

SAMBROCK, J.; FRITSCH, E.F.; MANIATIS, T. Molecular cloning: a laboratory manual III. s.l. 2nd ed. New York, Cold Spring Harbor Laboratory Press, 1987. paginação irregular.

SAMUILOV, V.D.; OLESKIN, A.V.; LAGUNOVA, E.M. Programmed cell death. Biochemistry-Moscow, New York, v. 65, n.8, p.873-887, 2000

SARRUGE, J.R. Soluções nutritivas. Summa phytopathologica, Piracicaba, v.1, n.3, p. 2312331, 1975.

SCHUSSLER, A.; SCHWARZOTT, D.; WALKER, C. A new fungal phylum, the Glomeromycota: phylogeny and evolution. Mycological Research, New York, v.105, n.12, 1413-1421, 2001.

SCHLUMBAUM, A.; MAUCH, F.; VOGELI, U. et al. Plant chitinases ar potential inhibitors of fungal growth. Nature, London,v. 324, n. 3, p. 365-367, 1986.

SHIRTLIFFE, S.J.; VESSEY, J.K. A nodulation ( $\left.\mathrm{Nod}^{+} / \mathrm{Fix}{ }^{-}\right)$mutante of Phaseolus vulgaris L. has nodule like strutures lacking peripheral vascular bundles $\left(\mathrm{Pvb}^{-}\right)$and is resistent to mycorrhizal infection (Myc ${ }^{-}$). Plant Science, Clare, v. 118, n. 2, p. 209-220, 1996.

SHOWALTER, A.M. Structure and function of plant cell wall proteins. Plant Cell, Rockville, v.5,n.1, p.9-23, 1993.

SILVEIRA, A.P.D. Micorrizas. In: CARDOSO, E.J.B.N.; TSAI, S.M.; NEVES, M.C.P. (Ed.). Microbiologia do Solo. Campinas: Sociedade Brasileira de Ciência do Solo, 1992. cap. 16, p. 257-283.

SIQUEIRA, J.O.; FRANCO, A.A. Biotecnologia do solo: fundamentos e perspectivas. Brasília: MEC/ABEAS/Lavras: ESAL/ FAEPE, 1988. 236p.

SIQUEIRA, J.O.; COLOZZI-FILHO, A.; OLIVEIRA, E. Ocorrência de micorrizas vesiculararbusculares em agro e ecossistemas do Estado de Minas Gerais. Pesquisa Agropecuária Brasileira, Brasilia, v.24, n.12, p.1499-1506, 1989.

SIQUEIRA, J.O.; POUYÚ, E.; MOREIRA, F.M.S. Micorrizas arbusculares no crescimento póstransplantio de mudas de árvores em solos com excesso de metais pesados. Revista Brasileira de Ciência do Solo, Campinas, v.23, n.5, p. 569-580, 1999.

SMITH, G.S.; GIANIAZZI-PEARSON, V. Physiological interactions between symbionts in vesicular-arbuscular mycorrhizal plants. Annual Reviews of Plant Physiology and Plant Molecular Biology, Stanford, v. 32, n. 1, p. 393-409, 1988. 
SPANU, P.; BOLLER, T.; LUDWIG, A. et al. Chitinase in mycorrhizal Allium porrum: regulation and localization. Planta, New York, v.177, n. 3, p. 447-455, 1989.

STOMMEL, M.; MANN, P.; FRANKEN, P. EST-library construction using spore RNA of the arbuscular mycorrhizal fungus Gigaspora rosea. Mycorrhiza, New York, v.10, n.6, p.281-285, 2001.

SZCZYGLOWSKI, K.; HAMBURGER, D.; KAPRANOV, P. et al. Construction of a Lotus japonicus late nodulin expressed sequence tag library and identification of novel nodule-specific genes. Plant Physiology, Rockville, v.114, n.4, p.1335-1346, 1997.

TAKAHASHI, D.; MATSUOKA, S.; MENEGHIN, S.P. Diferencial de micorrizas arbusculares de solo virgem e de solo cultivado com cana-de-açúcar. In: CONGRESSO DE INICIAÇÃO CIENTÍFICA, 6., 1998 São Carlos. Resumos... São Carlos: Pró-Reitoria de Pós-Graduação e Pesquisa, 1998. p.BA082

TELLES, G.P.; SILVA, F.R. Trimming and clustering sugarcane ESTs. Genetics and Molecular Biology, Ribeirão Preto, v.21, n.1/4, p.17-23, 2001.

TESTER, M.; SMITH, S.E.; SMITH, F.A. The phenomenon os "non-mycorrhizal" plants. Candian Journal of Botany, Ottawa, v. 65, n. 3, p. 419-431, 1987.

UHDE-STONE, C.; ZINN, K.E.; RAMIREZ-YANEZ, M. Nylon filters arrays reveal differential gene expression in proteoid roots of white lupin in response to phosphorus deficiency. Plant Physiology, Rockville, v.113, n.3, p.1064-1079, 2003.

VERDOUCQ, L.; VIGNOLS, F.; JACQUOT, J.P. et al. In vivo characterization of a thioredoxin $\mathrm{h}$ target protein defines a new peroxiredoxin family. Journal of Biological Chemistry, Rockville, v.274, n.28, p.19714-19722, 1999.

VETTORE, A.L. et al. Analysis and functional annotation of an expressed sequence tag collection for tropical crop sugarcane. Genome Research, Woodburry, v.13, n.12, p.2725-2735, 2003.

van BUUREN, M.L.; MALDONADO-MENDOZA, I.E.; TRIEU, A.T. et al. Novel genes induced during arbuscular mycorrhizal (AM) symbiosis between $M$. truncatula and $G$. versiforme. Molecular Plant-Microbe Interactions, St. Paul, v. 12, n. 1, p. 171-181, 1999.

van RHIJN, M.L.; FANG, Y.; GALILI, S. et al. Expression of early nodulin genes in alfaf mycorrhizae indicates that signal transduction pathways used in forming arbuscular mycorrhizae and Rhizobium-induced nodules may be conserved. Proceedings of the National Academy of Science (USA), New York, v.94, n.12, p. 5467-5472, 1997.

VIERHEILIG, H.; NEUHAUS, A.M.; BOLLER, J.M. et al. Colonization of transgenic Nicotiana sylvestris plants, expressing different forms of Nicotiana tabacum chitinase, by the root pathogen Rhizoctonia solani and by the mycorrhizal symbiont Glomus mosseae. Molecular Plant-Microbe Interactions, St. Paul, v. 6, n. 2, p. 261-264, 1993. 
VIERHEILIG, H.; COUGHLAN, A.P; WYSS, U. et al. Ink and vinegar, a simple staining for arbuscular-mycorrhizal fungi. Applied and Environmental Microbiology, Washington, v. 64, n. 12, p. 5004-5007, 1998.

VOIBLET, C.; DUPLESSIS, S, ENCELOT, N. et al. Identification of symbiosis-regulated genes in Eucalyptus globulus-Pisolithus tinctorius ectomycorrhiza by differential hybridization of arrayed cDNAs. Plant Journal, Oxford, UK, v.25, n. 2, p.181-191, 2001.

VOLPIN, H.; ELKIND, Y.; KAPULNIK, Y. A vesicular arbuscular mycorrhizal fungus Glomus intraradix induces a defense response in alfafa roots. Plant Physiology, Rockville, v. 104, n. 5, p. 683-689, 1994.

VOLPIN, H.; PHILLIPS, D.A.; OKON, Y. et al. Supression of an isofalvonoid phytoalexin defense response in mycorrhizal alfafa roots. Plant Physiology, Rockville, v. 108, n.12, p. 14491454. 1995.

WALKER, J.C. Structure and function of the receptor-like protein kinases of higher plants. Plant Molecular Biology, Dordrecht v. 26, n. 12, p.1599-1609, 1994.

WRIGHT, S.F.; UPADHYAYA, A. Extraction of an abundant and unusual protein from soil and comparasion with hyphal protein of arbuscular mycorrhizal fungi. Soil Science, v. 161, n. 3, p. 575-586, 1996.

WRIGTH, S.F.; FRANKE-SNYDER, M.; MORTON, J.B. et al. Time-scourse study and partial characterization of a protein on hyphae of arbuscular mycorrhizal fungi during active colonization of roots. Plant and Soil, New Brunswick, v. 181, n. 2, p. 193-203, 1996.

WULF, A.; MANTHEY, K.; DOLL, J. et al. Transcriptional changes in response to arbuscular mycorrhiza development in the model plant Medicago truncatula. Molecular Plant-Microbe Interactions, St. Paul, v.16, n. 4, p. 306-314, 2003.

YANG, Q.; TRINH, H.X.; IMAI, S. et al. Analysis of the involvemente of hydroxyanthranilate hydroxycinnamoyltransferase and caffeoyl-CoA 3-O-methyltransferase in phytoalexin biosynthesis in oat. Molecular Plant-Microbe Interactions, St. Paul, v. 17, n. 1, p. 81-89, 2004.

ZHOU, D.G.; CHEN, L.M.; HERNANDEZ, L. et al. A Salmonella inositol polyphosphatase acts in conjunction with other bacterial effectors to promote host cell actin cytoskeleton rearrangements and bacterial internalization. Molecular Microbiology, Oxford (UK), v.39, n.2, p.248-259, 2001. 
ANEXOS 
Anexo 1

Solução OLB

$\mathrm{A}: \mathrm{B}: \mathrm{C}=(1: 2,5: 1,5)$

Solução A

$1 \mathrm{~mL}$ de solução $\mathrm{O}$

$18 \mu \mathrm{L}$ de 2-mercaptoetanol

$5 \mu \mathrm{L}$ de $100 \mathrm{mM}$ dTTG

$5 \mu \mathrm{L}$ de $100 \mathrm{mM}$ dGTG

$5 \mu \mathrm{L}$ de $100 \mathrm{mM}$ dATG

Solução O

1,25 M de Tris-HCl, pH 8

$125 \mathrm{mM}$ de $\mathrm{MgCl}_{2}$

Solução B

2 M HEPES-NaOH, pH 6,6

Solução C

3 mM de Tris-HCl, pH 7,4

0,2 mM de EDTA 
Anexo 2 - Similaridades entre ESTs com expressão induzida em raízes de cana-de-açúcar inoculadas com Glomus clarum em relação ao controle não-inoculado e adubadas com $20 \mathrm{mg} \mathrm{kg}^{-1}$ e seqüiências depositadas nos bancos de dados NCBI ou SUCEST. As seqências foram comparadas utilizando-se o algoritmo Blast

\begin{tabular}{|c|c|c|c|c|}
\hline Cluster & Read & Tamanho & E-value Similar a & Base \\
\hline SCESMS1008A04.g & 53 & 392 & 9,00E-47 proprotein convertase aPC6C isoform & SUCEST \\
\hline SCESMS1008F10.g & 24 & 325 & 3,00E-49 metallothionein 2b & SUCEST \\
\hline SCESMS1008C06.g & 15 & 483 & 1,00E-27 synapsin I, alt. transcript 1 (Homo sapiens) & SUCEST \\
\hline SCESMS1002C04.g & 4 & 301 & $\begin{array}{l}\text { 6,00E-30 caffeoyl-CoA O-methyltransferase - like } \\
\text { protein }\end{array}$ & SUCEST \\
\hline SCESMS1002D02.g & 4 & 616 & 6,00E-23 Ac1147 [Rattus norvegicus] & NCBI \\
\hline SCESMS1008D03.g & 3 & 887 & 2,00E-21 Ac1147 [Rattus norvegicus] & NCBI \\
\hline SCESMS1001G10.g & 2 & 405 & $\begin{array}{l}\text { 2,00E-21 rRNA intron-encoded homing endonuclease } \\
\text { [Oryza sativa] }\end{array}$ & $\mathrm{NCBI}$ \\
\hline SCESMS1002F07.g & 1 & 620 & 1,00E-116 elongation factor 1-alpha [Zea mays] & SUCEST \\
\hline SCESMS1001E11.g & 1 & 252 & 4,00E-39 beta-tubulin [Oryza sativa] & SUCEST \\
\hline SCESMS1001D07.g & 1 & 187 & 6,00E-19 metallothionein 2b & SUCEST \\
\hline
\end{tabular}


Anexo 3 - Similaridades entre ESTs expressas em raízes de cana-de-açúcar inoculadas ou nãoinoculadas com Glomus clarum e adubadas com 20 ou $200 \mathrm{mg} \mathrm{kg}^{-1}$ e seqüências depositadas nos bancos de dados NCBI ou SUCEST. As seqências foram comparadas utilizando-se o algoritmo Blast

(continua)

\begin{tabular}{|c|c|c|c|c|c|}
\hline Cluster & Read & Tamanho & E-value & Blast & Base \\
\hline SCESMY1001A07.g & 4 & 1151 & 9,00E-97 & $\begin{array}{l}\text { putative senescence-associated protein } \\
\text { [Pisum sativum] }\end{array}$ & NCBI \\
\hline SCESMY1001G03.g & 2 & 1042 & $1,00 \mathrm{E}-131$ & HEAT SHOCK PROTEIN 82 & NCBI \\
\hline SCESMY1001B01.g & 2 & 672 & $1,00 \mathrm{E}-73$ & $\begin{array}{l}\text { P0692C11.18 [Oryza sativa (japonica } \\
\text { cultivar-group)] }\end{array}$ & NCBI \\
\hline SCESMY1001B07.g & 2 & 291 & $1,00 \mathrm{E}-12$ & $\begin{array}{l}\text { COG4948: L-alanine-DL-glutamate } \\
\text { epimerase and related enzymes of enolase } \\
\text { superfamily [Burkholderia cepacia R18194] }\end{array}$ & NCBI \\
\hline SCESMY1001E02.g & 2 & 652 & 2,00E-01 & fatty acid hydroxylase & SUCEST \\
\hline SCESMY1001C02.g & 1 & 654 & $1,00 \mathrm{E}-110$ & $\begin{array}{l}\text { methionine synthase protein [Sorghum } \\
\text { bicolor] }\end{array}$ & NCBI \\
\hline SCESMY1001A06.g & 1 & 608 & $1,00 \mathrm{E}-101$ & elongation factor 1-alpha [Zea mays] & NCBI \\
\hline SCESMY1001C04.g & 1 & 640 & 3,00E-97 & $\begin{array}{l}\text { COG1020: Non-ribosomal peptide synthetase } \\
\text { modules and related proteins [Pseudomonas } \\
\text { fluorescens PfO-1] }\end{array}$ & NCBI \\
\hline SCESMY1001A03.g & 1 & 647 & 1,00E-92 & $\begin{array}{l}\text { (AC000104) F19P19.16 [Arabidopsis } \\
\text { thaliana] }\end{array}$ & SUCEST \\
\hline SCESMY1001A12.g & 1 & 609 & 3,00E-92 & metallothionein-like protein - papaya & SUCEST \\
\hline SCESMY1001F05.g & 1 & 639 & 3,00E-91 & $\begin{array}{l}\text { COG0438: Glycosyltransferase } \\
\text { [Pseudomonas syringae pv. syringae B728a] }\end{array}$ & NCBI \\
\hline SCESMY1001D12.g & 1 & 572 & $1,00 \mathrm{E}-90$ & calnexin - like protein & SUCEST \\
\hline SCESMY1001C06.g & 1 & 636 & 2,00E-90 & $\begin{array}{l}\text { putative tryptophan synthase alpha chain } \\
\text { [Oryza sativa (japonica cultivar-group)] }\end{array}$ & NCBI \\
\hline SCESMY1001D08.g & 1 & 652 & 2,00E-88 & $\begin{array}{l}\text { COG4213: ABC-type xylose transport } \\
\text { system, periplasmic component } \\
\text { [Pseudomonas fluorescens PfO-1] }\end{array}$ & NCBI \\
\hline SCESMY1001E03.g & 1 & 643 & 4,00E-86 & $\begin{array}{l}\text { putative cytochrome P450-related protein } \\
\text { [Oryza sativa] }\end{array}$ & NCBI \\
\hline SCESMY1001E06.g & 1 & 643 & 4,00E-86 & $\begin{array}{l}\text { COG0515: Serine/threonine protein kinase } \\
\text { [Pseudomonas fluorescens PfO-1] }\end{array}$ & NCBI \\
\hline SCESMY1001F03.g & 1 & 641 & 2,00E-83 & $\begin{array}{l}\text { COG0598: Mg2+ and Co2+ transporters } \\
\text { [Pseudomonas fluorescens PfO-1] }\end{array}$ & NCBI \\
\hline SCESMY1001D11.g & 1 & 611 & $1,00 \mathrm{E}-77$ & $\begin{array}{l}\text { cinnamoyl-CoA reductase [Saccharum } \\
\text { officinarum] }\end{array}$ & SUCEST \\
\hline SCESMY1001H02.g & 1 & 590 & 4,00E-74 & $\begin{array}{l}\text { hypothetical protein FG04948.1 [Gibberella } \\
\text { zeae PH-1] }\end{array}$ & NCBI \\
\hline SCESMY1001E01.g & 1 & 458 & 9,00E-70 & glycine-rich protein & SUCEST \\
\hline SCESMY1001H04.g & 1 & 569 & $1,00 \mathrm{E}-69$ & $\begin{array}{l}\text { elongation factor } 1 \text { gamma-like protein } \\
\text { [Oryza sativa (japonica cultivar-group)] }\end{array}$ & NCBI \\
\hline SCESMY1001D05.g & 1 & 388 & 2,00E-68 & $\begin{array}{l}\text { heterochromatin protein homolog (Homo } \\
\text { sapiens) }\end{array}$ & SUCEST \\
\hline SCESMY1001A01.g & 1 & 659 & 2,00E-67 & cluster sem notação & SUCEST \\
\hline
\end{tabular}


Anexo 3 - Similaridades entre ESTs expressas em raízes de cana-de-açúcar inoculadas com Glomus clarum e adubadas com $20 \mathrm{mg} \mathrm{kg}^{-1}$ e seqüências depositadas nos bancos de dados NCBI ou SUCEST. As seqências foram comparadas utilizando-se o algoritmo Blast

(continuação)

\begin{tabular}{|c|c|c|c|c|c|}
\hline Cluster & Read & Tamanho & E-value & Blast & Base \\
\hline SCESMY1001B06.g & 1 & 624 & $4,00 \mathrm{E}-67$ & $\begin{array}{l}\text { putative ubiquitin-specific protease otubain } 1 \\
\text { [Oryza sativa (japonica cultivar-group)] }\end{array}$ & NCBI \\
\hline SCESMY1001A02.g & 1 & 603 & $9,00 \mathrm{E}-64$ & cluster sem notação & SUCEST \\
\hline SCESMY1001F10.g & 1 & 640 & 5,00E-61 & 40S ribosomal protein S16 & NCBI \\
\hline SCESMY1001B08.g & 1 & 320 & $7,00 \mathrm{E}-58$ & serine/threonine kinase-like protein & SUCEST \\
\hline SCESMY1001C09.g & 1 & 360 & $2,00 \mathrm{E}-56$ & $\begin{array}{l}\text { (AP002855) hypothetical protein [Oryza } \\
\text { sativa]" }\end{array}$ & SUCEST \\
\hline SCESMY1001E05.g & 1 & 626 & $3,00 \mathrm{E}-56$ & $\begin{array}{l}\text { pyoverdine synthetase A [Pseudomonas } \\
\text { fluorescens] }\end{array}$ & NCBI \\
\hline SCESMY1001H12.g & 1 & 821 & $8,00 \mathrm{E}-56$ & $\begin{array}{l}\text { COG1294: Cytochrome bd-type quinol } \\
\text { oxidase, subunit } 2 \text { [Pseudomonas fluorescens } \\
\text { PfO-1] }\end{array}$ & NCBI \\
\hline SCESMY1001D02.g & 1 & 286 & $1,00 \mathrm{E}-54$ & putative aspartic protease & SUCEST \\
\hline SCESMY1001G10.g & 1 & 687 & $5,00 \mathrm{E}-51$ & $\begin{array}{l}\text { putative cytochrome P450 [Oryza sativa } \\
\text { (japonica cultivar-group)] }\end{array}$ & NCBI \\
\hline SCESMY1001E04.g & 1 & 641 & $7,00 \mathrm{E}-50$ & $\begin{array}{l}\text { B1143G03.11 [Oryza sativa (japonica } \\
\text { cultivar-group)] }\end{array}$ & NCBI \\
\hline SCESMY1001F08.g & 1 & 263 & 8,00E-48 & $\begin{array}{l}\text { putative type } 1 \text { membrane protein } \\
\text { [Arabidopsis thaliana] }\end{array}$ & SUCEST \\
\hline SCESMY1001B04.g & 1 & 498 & $4,00 \mathrm{E}-47$ & mucin 2, intestinal & SUCEST \\
\hline SCESMY1001A09.g & 1 & 276 & $1,00 \mathrm{E}-46$ & Orf122 [Chlorobium tepidum]" & SUCEST \\
\hline SCESMY1001G12.g & 1 & 299 & $2,00 \mathrm{E}-43$ & metallothionein $2 \mathrm{~b}$ & SUCEST \\
\hline SCESMY1001D03.g & 1 & 638 & 3,00E-43 & $\begin{array}{l}\text { COG0583: Transcriptional regulator } \\
\text { [Ralstonia eutropha JMP134] }\end{array}$ & NCBI \\
\hline SCESMY1001F04.g & 1 & 554 & $7,00 \mathrm{E}-40$ & Tubulin alpha-3 chain (Alpha-3 tubulin) & NCBI \\
\hline SCESMY1001C08.g & 1 & 589 & $1,00 \mathrm{E}-37$ & $\begin{array}{l}\text { COG0667: Predicted oxidoreductases } \\
\text { (related to aryl-alcohol dehydrogenases) } \\
\text { [Burkholderia cepacia R18194] }\end{array}$ & NCBI \\
\hline SCESMY1001E07.g & 1 & 539 & $9,00 \mathrm{E}-35$ & $\begin{array}{l}\text { EF-hand Ca2+-binding protein CCD1 } \\
\text { [Triticum aestivum] }\end{array}$ & NCBI \\
\hline SCESMY1001C03.g & 1 & 653 & 1,00E-33 & $\begin{array}{l}\text { putative transcription factor RAU1 [Oryza } \\
\text { sativa (japonica cultivar-group)] }\end{array}$ & NCBI \\
\hline SCESMY1001B03.g & 1 & 229 & 2,00E-33 & putative myrosinase-binding protein & SUCEST \\
\hline SCESMY1001G01.g & 1 & 666 & $9,00 \mathrm{E}-32$ & $\begin{array}{l}\text { OSJNBa0018M05.13 [Oryza sativa (japonica } \\
\text { cultivar-group)] }\end{array}$ & NCBI \\
\hline SCESMY1001A10.g & 1 & 536 & $4,00 \mathrm{E}-28$ & $\begin{array}{l}\text { senescence-associated protein-like protein } \\
\text { [Oryza sativa (japonica cultivar-group)] }\end{array}$ & SUCEST \\
\hline SCESMY1001H05.g & 1 & 689 & $3,00 \mathrm{E}-26$ & $\begin{array}{l}\text { hypothetical protein [Oryza sativa (japonica } \\
\text { cultivar-group)] }\end{array}$ & NCBI \\
\hline SCESMY1001B12.g & 1 & 791 & 4,00E-25 & $\begin{array}{l}\text { tyrosine specific protein phosphatase family } \\
\text { protein [Arabidopsis thaliana] }\end{array}$ & NCBI \\
\hline SCESMY1001B11.g & 1 & 415 & $3,00 \mathrm{E}-22$ & Cluster sem notação (stress response) & SUCEST \\
\hline
\end{tabular}


Anexo 3 - Similaridades entre ESTs expressas em raízes de cana-de-açúcar inoculadas com Glomus clarum e adubadas com $20 \mathrm{mg} \mathrm{kg}^{-1}$ e seqüências depositadas nos bancos de dados NCBI ou SUCEST. As seqências foram comparadas utilizando-se o algoritmo Blast

(conclusão)

\begin{tabular}{|c|c|c|c|c|c|}
\hline Cluster & Read & Tamanho & E-value & Blast & Base \\
\hline SCESMY1001B05.g & 1 & 206 & $3,00 \mathrm{E}-20$ & $\begin{array}{l}\text { AGR_pAT_496p [Agrobacterium } \\
\text { tumefaciens str. C58] }\end{array}$ & NCBI \\
\hline SCESMY1001G11.g & 1 & 716 & $2,00 \mathrm{E}-19$ & $\begin{array}{l}\text { OSJNBa0041M06.4 [Oryza sativa (japonica } \\
\text { cultivar-group)] }\end{array}$ & NCBI \\
\hline SCESMY1001D01.g & 1 & 645 & $3,00 \mathrm{E}-18$ & $\begin{array}{l}\text { hypothetical protein [Oryza sativa (japonica } \\
\text { cultivar-group)] }\end{array}$ & NCBI \\
\hline SCESMY1001H06.g & 1 & 637 & $3,00 \mathrm{E}-17$ & $\begin{array}{l}\text { ribosomal protein L19 family protein } \\
\text { [Arabidopsis thaliana] }\end{array}$ & NCBI \\
\hline SCESMY1001G05.g & 1 & 643 & $7,00 \mathrm{E}-17$ & $\begin{array}{l}\text { P0534A03.10 [Oryza sativa (japonica } \\
\text { cultivar-group)] }\end{array}$ & NCBI \\
\hline SCESMY1001F09.g & 1 & 441 & $2,00 \mathrm{E}-16$ & $\begin{array}{l}\text { putative LRR receptor-like kinase [Oryza } \\
\text { sativa (japonica cultivar-group)] }\end{array}$ & NCBI \\
\hline SCESMY1001F06.g & 1 & 600 & $1,00 \mathrm{E}-15$ & patatin-related [Arabidopsis thaliana] & NCBI \\
\hline SCESMY1001E12.g & 1 & 355 & $5,00 \mathrm{E}-15$ & $\begin{array}{l}\text { putative phosphoribosylanthranilate } \\
\text { transferase [Cryptomeria japonica] }\end{array}$ & NCBI \\
\hline SCESMY1001F11.g & 1 & 677 & $1,00 \mathrm{E}-13$ & orf107a [Arabidopsis thaliana] & NCBI \\
\hline SCESMY1001D09.g & 1 & 663 & $1,00 \mathrm{E}-11$ & $\begin{array}{l}\text { zinc finger (C2H2 type) family protein } \\
\text { [Arabidopsis thaliana] }\end{array}$ & NCBI \\
\hline SCESMY1001B10.g & 1 & 556 & 3,00E-11 & $\begin{array}{l}\text { putative branched-chain amino acid } \\
\text { aminotransferase protein [Oryza sativa } \\
\text { (japonica cultivar-group)] }\end{array}$ & NCBI \\
\hline SCESMY1001E11.g & 1 & 508 & $6,00 \mathrm{E}-11$ & $\begin{array}{l}\text { unknown protein [Oryza sativa (japonica } \\
\text { cultivar-group)] }\end{array}$ & NCBI \\
\hline SCESMY1001G04.g & 1 & 322 & 8,00E-11 & $\begin{array}{l}\text { COG3658: Cytochrome b [Pseudomonas } \\
\text { syringae pv. syringae B728a] }\end{array}$ & NCBI \\
\hline SCESMY1001G09.g & 1 & 612 & $9,00 \mathrm{E}-11$ & predicted protein [Magnaporthe grisea 70-15] & NCBI \\
\hline SCESMY1001H03.g & 1 & 363 & $5,00 \mathrm{E}-10$ & TOLA PROTEIN - ESCHERICHIA COLI & SUCEST \\
\hline SCESMY1001F01.g & 1 & 309 & 2,00E-09 & aleurone ribonuclease (EC 3.1.-.-) - barley & NCBI \\
\hline SCESMY1001C07.g & 1 & 198 & $1,00 \mathrm{E}-07$ & $\begin{array}{l}\text { TonB-dependent receptor protein } \\
\text { [Nitrosomonas europaea ATCC 19718] }\end{array}$ & NCBI \\
\hline SCESMY1001E09.g & 1 & 192 & $5,00 \mathrm{E}-04$ & serine/threonine kinase-like protein & SUCEST \\
\hline SCESMY1001D06.g & 1 & 171 & $2,60 \mathrm{E}-01$ & cluster sem notação & SUCEST \\
\hline SCESMY1001A04.g & 1 & 225 & 6,60E-01 & cluster sem notação & SUCEST \\
\hline
\end{tabular}


Anexo 4 - Similaridades entre ESTs expressas em raízes de cana-de-açúcar inoculadas e adubadas com $20 \mathrm{mg} \mathrm{kg}^{-1}$ e seqüências depositadas nos bancos de dados NCBI ou SUCEST. As seqências foram comparadas utilizando-se o algoritmo Blast

(continua)

\begin{tabular}{|c|c|c|c|c|c|}
\hline Cluster & Read & Tamanho & E-value & Blast & Base \\
\hline SCESMY2002A10.g & 3 & 668 & $8,00 \mathrm{E}-23$ & $\begin{array}{l}\text { hypothetical protein [Photorhabdus luminescens } \\
\text { subsp. laumondii TTO1] }\end{array}$ & NCBI \\
\hline SCESMY2003A05.g & 2 & 695 & $1,00 \mathrm{E}-120$ & $\begin{array}{l}\text { COG2509: Uncharacterized FAD-dependent } \\
\text { dehydrogenases [Pseudomonas fluorescens PfO-1] }\end{array}$ & NCBI \\
\hline SCESMY2003F06.g & 2 & 662 & $1,00 \mathrm{E}-118$ & $\begin{array}{l}\text { COG1960: Acyl-CoA dehydrogenases } \\
\text { [Pseudomonas fluorescens PfO-1] }\end{array}$ & NCBI \\
\hline SCESMY2001A11.g & 2 & 632 & $8,00 \mathrm{E}-59$ & $\begin{array}{l}\text { COG2831: Hemolysin activation/secretion protein } \\
\text { [Pseudomonas fluorescens PfO-1] }\end{array}$ & NCBI \\
\hline SCESMY2001H02.g & 2 & 374 & $1,00 \mathrm{E}-38$ & $\begin{array}{l}\text { COG1879: ABC-type sugar transport system, } \\
\text { periplasmic component [Azotobacter vinelandii] }\end{array}$ & NCBI \\
\hline SCESMY2002B02.g & 2 & 231 & $6,00 \mathrm{E}-26$ & $\begin{array}{l}\text { probable LysR-family transcriptional regulator } \\
\text { [Bordetella bronchiseptica RB50] }\end{array}$ & NCBI \\
\hline SCESMY2001C10.g & 1 & 733 & $1,00 \mathrm{E}-143$ & cluster sem notação & SUCEST \\
\hline SCESMY2002D02.g & 1 & 665 & $1,00 \mathrm{E}-140$ & $60 \mathrm{~S}$ ribosomal protein $\mathrm{L} 13, \mathrm{BBC} 1$ protein & SUCEST \\
\hline SCESMY2002F06.g & 1 & 806 & $1,00 \mathrm{E}-139$ & $\begin{array}{l}\text { putative fructose-bisphosphate aldolase [Oryza } \\
\text { sativa (japonica cultivar-group)] }\end{array}$ & NCBI \\
\hline SCESMY2001C06.g & 1 & 821 & $1,00 \mathrm{E}-130$ & $\begin{array}{l}\text { wheat adenosylhomocysteinase-like protein [Oryza } \\
\text { sativa (japonica cultivar-group)] }\end{array}$ & NCBI \\
\hline SCESMY2003G07.g & 1 & 770 & $1,00 \mathrm{E}-130$ & cluster sem notação & SUCEST \\
\hline SCESMY2002C06.g & 1 & 673 & $1,00 \mathrm{E}-111$ & $\begin{array}{l}\text { COG3852: Signal transduction histidine kinase, } \\
\text { nitrogen specific [Pseudomonas fluorescens PfO-1] }\end{array}$ & NCBI \\
\hline SCESMY2001B12.g & 1 & 686 & $1,00 \mathrm{E}-109$ & $\begin{array}{l}\text { COG1034: NADH } \\
\text { dehydrogenase/NADH:ubiquinone oxidoreductase } \\
75 \text { kD subunit (chain G) [Pseudomonas fluorescens } \\
\text { PfO-1] }\end{array}$ & NCBI \\
\hline SCESMY2003E10.g & 1 & 812 & $1,00 \mathrm{E}-107$ & $\begin{array}{l}\text { En/Spm-like transposon protein related to En/Spm } \\
\text { transposon family of maize }\end{array}$ & SUCEST \\
\hline SCESMY2003B03.g & 1 & 796 & $1,00 \mathrm{E}-106$ & $\begin{array}{l}\text { isovaleryl-CoA dehydrogenase [Bordetella } \\
\text { bronchiseptica RB50] }\end{array}$ & NCBI \\
\hline SCESMY2003B08.g & 1 & 703 & $1,00 \mathrm{E}-106$ & $\begin{array}{l}\text { COG2853: Surface lipoprotein [Pseudomonas } \\
\text { fluorescens PfO-1] }\end{array}$ & NCBI \\
\hline SCESMY2002F07.g & 1 & 673 & $1,00 \mathrm{E}-103$ & polyubiquitin [Aster tripolium] & NCBI \\
\hline SCESMY2003F08.g & 1 & 756 & $1,00 \mathrm{E}-103$ & $\begin{array}{l}\text { putative uridine kinase/uracil } \\
\text { phosphoribosyltransferase [Oryza sativa (japonica } \\
\text { cultivar-group)] }\end{array}$ & NCBI \\
\hline SCESMY2003A11.g & 1 & 721 & $1,00 \mathrm{E}-102$ & sucrose synthase-2 [Saccharum officinarum] & NCBI \\
\hline SCESMY2003E03.g & 1 & 700 & $1,00 \mathrm{E}-101$ & $\begin{array}{l}\text { probable 3-hydroxybutyryl-CoA dehydrogenase } \\
\text { [Bordetella parapertussis 12822] }\end{array}$ & NCBI \\
\hline SCESMY2001C01.g & 1 & 651 & $1,00 \mathrm{E}-100$ & $\begin{array}{l}\text { putative orotidine } 5 \text { '-phosphate decarboxylase } \\
\text { [Bordetella pertussis Tohama I] }\end{array}$ & NCBI \\
\hline SCESMY2001B03.g & 1 & 771 & 9,00E-96 & $\begin{array}{l}\text { unknown protein [Oryza sativa (japonica cultivar- } \\
\text { group)] }\end{array}$ & NCBI \\
\hline SCESMY2003D08.g & 1 & 826 & 2,00E-93 & $\begin{array}{l}\text { COG1080: Phosphoenolpyruvate-protein kinase } \\
\text { (PTS system EI component in bacteria) } \\
\text { [Pseudomonas fluorescens PfO-1] }\end{array}$ & NCBI \\
\hline
\end{tabular}


Anexo 4 - Similaridades entre ESTs expressas em raízes de cana-de-açúcar inoculadas e adubadas com $20 \mathrm{mg} \mathrm{kg}^{-1}$ e seqüências depositadas nos bancos de dados NCBI ou SUCEST. As seqências foram comparadas utilizando-se o algoritmo Blast

(continuação)

\begin{tabular}{|c|c|c|c|c|c|}
\hline Cluster & Read & Tamanho & E-value & Blast & Base \\
\hline SCESMY2003C03.g & 1 & 819 & 5,00E-93 & Tubulin beta-7 chain (Beta-7 tubulin) & NCBI \\
\hline SCESMY2002C07.g & 1 & 708 & 6,00E-93 & $\begin{array}{l}\text { putative phosphohydrolase [Bordetella parapertussis } \\
12822 \text { ] }\end{array}$ & NCBI \\
\hline SCESMY2003A10.g & 1 & 733 & 1,00E-92 & $\begin{array}{l}\text { COG4213: ABC-type xylose transport system, } \\
\text { periplasmic component [Pseudomonas fluorescens } \\
\text { PfO-1] }\end{array}$ & NCBI \\
\hline SCESMY2003H07.g & 1 & 776 & 1,00E-91 & $\begin{array}{l}\text { COG0745: Response regulators consisting of a } \\
\text { CheY-like receiver domain and a winged-helix } \\
\text { DNA-binding domain [Pseudomonas fluorescens } \\
\text { PfO-1] }\end{array}$ & NCBI \\
\hline SCESMY2001H11.g & 1 & 632 & 2,00E-91 & polyubiquitin (UBQ4) [Arabidopsis thaliana] & NCBI \\
\hline SCESMY2003F05.g & 1 & 469 & 8,00E-89 & MtN3-like protein & SUCEST \\
\hline SCESMY2003G12.g & 1 & 710 & 5,00E-86 & $\begin{array}{l}\text { COG0436: Aspartate/tyrosine/aromatic } \\
\text { aminotransferase [Pseudomonas fluorescens PfO-1] }\end{array}$ & NCBI \\
\hline SCESMY2001D08.g & 1 & 782 & 1,00E-85 & $\begin{array}{l}\text { COG0583: Transcriptional regulator [Pseudomonas } \\
\text { fluorescens PfO-1] }\end{array}$ & NCBI \\
\hline SCESMY2003A03.g & 1 & 716 & $1,00 \mathrm{E}-85$ & $\begin{array}{l}\text { cis,cis-muconate cycloisomerase CatB } \\
\text { [Pseudomonas sp. CA10] }\end{array}$ & NCBI \\
\hline SCESMY2002B07.g & 1 & 730 & 6,00E-83 & $\begin{array}{l}\text { OSJNBa0038J17.24 [Oryza sativa (japonica } \\
\text { cultivar-group)] }\end{array}$ & NCBI \\
\hline SCESMY2001B11.g & 1 & 747 & 2,00E-81 & $\begin{array}{l}\text { COG0477: Permeases of the major facilitator } \\
\text { superfamily [Pseudomonas fluorescens PfO-1] }\end{array}$ & NCBI \\
\hline SCESMY2003E06.g & 1 & 730 & $3,00 \mathrm{E}-81$ & $\begin{array}{l}\text { Eukaryotic translation initiation factor 5A (eIF-5A) } \\
\text { (eIF-4D) }\end{array}$ & NCBI \\
\hline SCESMY2003H05.g & 1 & 749 & 4,00E-77 & ubiquitin-conjugating enzyme E2 - maize & NCBI \\
\hline SCESMY2001F02.g & 1 & 764 & $5,00 \mathrm{E}-77$ & $\begin{array}{l}\text { r40c1 protein - rice gi|1296955|emb|CAA64683.1| } \\
\text { osr40c1 [Oryza sativa] }\end{array}$ & NCBI \\
\hline SCESMY2001D04.g & 1 & 752 & 4,00E-76 & $\begin{array}{l}\text { eukaryotic translation initiation factor } 3 \text { subunit } 3 \text { / } \\
\text { eIF-3 gamma / eIF3h (TIF3H1) [Arabidopsis } \\
\text { thaliana] }\end{array}$ & NCBI \\
\hline SCESMY2001E01.g & 1 & 375 & $2,00 \mathrm{E}-75$ & protein kinase -like protein & SUCEST \\
\hline SCESMY2002F04.g & 1 & 731 & 6,00E-75 & $\begin{array}{l}\text { L-carnitine dehydrogenase-like protein } \\
\text { [Acinetobacter sp. NCIMB9871] }\end{array}$ & NCBI \\
\hline SCESMY2003D01.g & 1 & 797 & 4,00E-72 & $\begin{array}{l}\text { Putative membrane protein [Oryza sativa (japonica } \\
\text { cultivar-group)] }\end{array}$ & NCBI \\
\hline SCESMY2002H06.g & 1 & 742 & $7,00 \mathrm{E}-72$ & Phyb1 [Pimpinella brachycarpa] & NCBI \\
\hline SCESMY2001G07.g & 1 & 734 & 1,00E-68 & $\begin{array}{l}\text { COG1020: Non-ribosomal peptide synthetase } \\
\text { modules and related proteins [Pseudomonas } \\
\text { fluorescens PfO-1] }\end{array}$ & NCBI \\
\hline SCESMY2002D01.g & 1 & 600 & $7,00 \mathrm{E}-67$ & $\begin{array}{l}\text { COG0477: Permeases of the major facilitator } \\
\text { superfamily [Burkholderia cepacia R18194] }\end{array}$ & NCBI \\
\hline SCESMY2001H05.g & 1 & 600 & 2,00E-66 & collagen, type I, alpha 2 (Homo sapiens) & SUCEST \\
\hline SCESMY2002B01.g & 1 & 644 & $2,00 \mathrm{E}-64$ & $\begin{array}{l}\text { COG1020: Non-ribosomal peptide synthetase } \\
\text { modules and related proteins [Pseudomonas } \\
\text { fluorescens PfO-1] }\end{array}$ & NCBI \\
\hline
\end{tabular}


Anexo 4 - Similaridades entre ESTs expressas em raízes de cana-de-açúcar inoculadas e adubadas com $20 \mathrm{mg} \mathrm{kg}^{-1}$ e seqüências depositadas nos bancos de dados NCBI ou SUCEST. As seqências foram comparadas utilizando-se o algoritmo Blast

(continuação)

\begin{tabular}{|c|c|c|c|c|c|}
\hline Cluster & Read & Tamanho & E-value & Blast & Base \\
\hline SCESMY2003F01.g & 1 & 709 & $2,00 \mathrm{E}-64$ & $\begin{array}{l}\text { COG2133: Glucose/sorbosone dehydrogenases } \\
\text { [Pseudomonas syringae pv. syringae B728a] }\end{array}$ & NCBI \\
\hline SCESMY2001C08.g & 1 & 750 & 8,00E-63 & OsNAC8 protein [Oryza sativa] & SUCEST \\
\hline SCESMY2001D03.g & 1 & 783 & 8,00E-63 & expressed protein [Arabidopsis thaliana] & NCBI \\
\hline SCESMY2002H03.g & 1 & 393 & 1,00E-62 & $\begin{array}{l}\text { COG1092: Predicted SAM-dependent } \\
\text { methyltransferases [Pseudomonas fluorescens PfO- } \\
\text { 1] }\end{array}$ & NCBI \\
\hline SCESMY2001B04.g & 1 & 571 & $2,00 \mathrm{E}-61$ & $\begin{array}{l}\text { COG2230: Cyclopropane fatty acid synthase and } \\
\text { related methyltransferases [Desulfitobacterium } \\
\text { hafniense] }\end{array}$ & NCBI \\
\hline SCESMY2003G08.g & 1 & 683 & 3,00E-61 & $\begin{array}{l}\text { glycosyl transferase family } 8 \text { protein [Arabidopsis } \\
\text { thaliana] }\end{array}$ & NCBI \\
\hline SCESMY2002D06.g & 1 & 808 & $8,00 \mathrm{E}-61$ & $\begin{array}{l}\text { hypothetical protein [Oryza sativa (japonica } \\
\text { cultivar-group)] }\end{array}$ & NCBI \\
\hline SCESMY2002D10.g & 1 & 770 & $1,00 \mathrm{E}-59$ & $\begin{array}{l}\text { Putative regulatory protein [Bordetella } \\
\text { bronchiseptica RB50] }\end{array}$ & NCBI \\
\hline SCESMY2003C02.g & 1 & 417 & $1,00 \mathrm{E}-59$ & $\begin{array}{l}\text { phosphate ABC transporter, permease protein } \\
\text { [Pseudomonas putida KT2440] }\end{array}$ & NCBI \\
\hline SCESMY2002B09.g & 1 & 666 & 2,00E-58 & $\begin{array}{l}\text { COG0155: Sulfite reductase, beta subunit } \\
\text { (hemoprotein) [Pseudomonas syringae pv. syringae } \\
\text { B728a] }\end{array}$ & NCBI \\
\hline SCESMY2001D01.g & 1 & 663 & $9,00 \mathrm{E}-58$ & $\begin{array}{l}\text { COG0607: Rhodanese-related sulfurtransferase } \\
\text { [Azotobacter vinelandii] }\end{array}$ & NCBI \\
\hline SCESMY2002F05.g & 1 & 703 & $2,00 \mathrm{E}-57$ & $\begin{array}{l}\text { putative arabinogalactan protein [Oryza sativa } \\
\text { (japonica cultivar-group)] }\end{array}$ & NCBI \\
\hline SCESMY2001G11.g & 1 & 664 & $1,00 \mathrm{E}-54$ & $\begin{array}{l}\text { conserved hypothetical protein [Pseudomonas } \\
\text { putida KT2440] }\end{array}$ & NCBI \\
\hline \multirow[t]{2}{*}{ SCESMY2002E06.g } & \multirow[t]{2}{*}{1} & \multirow[t]{2}{*}{671} & \multirow[t]{2}{*}{$6,00 \mathrm{E}-54$} & & \multirow[t]{2}{*}{ NCBI } \\
\hline & & & & $\begin{array}{l}\text { COG2912: Uncharacterized conserved protein } \\
\text { [Pseudomonas fluorescens PfO-1] }\end{array}$ & \\
\hline SCESMY2001G02.g & 1 & 651 & $1,00 \mathrm{E}-53$ & $\begin{array}{l}\text { COG0477: Permeases of the major facilitator } \\
\text { superfamily [Azotobacter vinelandii] }\end{array}$ & NCBI \\
\hline SCESMY2002B04.g & 1 & 719 & 2,00E-53 & histone $\mathrm{H} 1$, partial & SUCEST \\
\hline SCESMY2003F07.g & 1 & 752 & 9,00E-53 & protein F18014.27 [imported] & NCBI \\
\hline SCESMY2002G09.g & 1 & 618 & 2,00E-48 & 14-3-3-LIKE PROTEIN GF14-6 & NCBI \\
\hline SCESMY2002A06.g & 1 & 771 & $4,00 \mathrm{E}-48$ & $\begin{array}{l}\text { putative membrane protein [Bordetella } \\
\text { bronchiseptica RB50] }\end{array}$ & NCBI \\
\hline SCESMY2001F03.g & 1 & 715 & $2,00 \mathrm{E}-46$ & $\begin{array}{l}\text { putative 3-(2-hydroxyphenyl) propionic acid } \\
\text { transporter [Streptomyces avermitilis MA-4680] }\end{array}$ & NCBI \\
\hline SCESMY2001D05.g & 1 & 756 & $3,00 \mathrm{E}-45$ & Histidine ammonia-lyase (Histidase) & NCBI \\
\hline SCESMY2001C04.g & 1 & 612 & 2,00E-44 & $\begin{array}{l}\text { PROTEIN TRANSLATION FACTOR SUI1 } \\
\text { HOMOLOG (GOS2 PROTEIN) }\end{array}$ & NCBI \\
\hline SCESMY2003D12.g & 1 & 701 & $3,00 \mathrm{E}-44$ & $\begin{array}{l}\text { hypothetical protein AN0823.2 [Aspergillus } \\
\text { nidulans FGSC A4] }\end{array}$ & NCBI \\
\hline
\end{tabular}


Anexo 4 - Similaridades entre ESTs expressas em raízes de cana-de-açúcar inoculadas e adubadas com $20 \mathrm{mg} \mathrm{kg}^{-1}$ e seqüências depositadas nos bancos de dados NCBI ou SUCEST. As seqências foram comparadas utilizando-se o algoritmo Blast

(continuação)

\begin{tabular}{|c|c|c|c|c|c|}
\hline Cluster & Read & Tamanho & E-value & Blast & Base \\
\hline SCESMY2003B05.g & 1 & 261 & $1,00 \mathrm{E}-42$ & $\begin{array}{l}\text { COG0337: 3-dehydroquinate synthetase } \\
\text { [Pseudomonas syringae pv. syringae B728a] }\end{array}$ & NCBI \\
\hline SCESMY2001A02.g & 1 & 540 & $6,00 \mathrm{E}-42$ & $\begin{array}{l}\text { COG3048: D-serine dehydratase [Ralstonia } \\
\text { eutropha JMP134] }\end{array}$ & NCBI \\
\hline SCESMY2001E06.g & 1 & 700 & $8,00 \mathrm{E}-42$ & $\begin{array}{l}\text { unnamed protein product [Oryza sativa (japonica } \\
\text { cultivar-group)] }\end{array}$ & NCBI \\
\hline SCESMY2003F09.g & 1 & 663 & $4,00 \mathrm{E}-41$ & $\begin{array}{l}\text { Thioredoxin H-type (TRX-H) (Phloem sap } 13 \text { kDa } \\
\text { protein-1) }\end{array}$ & NCBI \\
\hline SCESMY2001B05.g & 1 & 535 & 3,00E-38 & $\begin{array}{l}\text { COG3511: Phospholipase C [Desulfitobacterium } \\
\text { hafniense] }\end{array}$ & NCBI \\
\hline SCESMY2003C09.g & 1 & 765 & $3,00 \mathrm{E}-37$ & $\begin{array}{l}\text { COG0659: Sulfate permease and related } \\
\text { transporters (MFS superfamily) [Ralstonia eutropha } \\
\text { JMP134] }\end{array}$ & NCBI \\
\hline SCESMY2001G03.g & 1 & 732 & $5,00 \mathrm{E}-36$ & long cell-linked locus protein [Zea mays] & NCBI \\
\hline SCESMY2003D05.g & 1 & 448 & $1,00 \mathrm{E}-34$ & $\begin{array}{l}\text { COG0583: Transcriptional regulator [Pseudomonas } \\
\text { fluorescens PfO-1] }\end{array}$ & NCBI \\
\hline SCESMY2001C12.g & 1 & 266 & 2,00E-33 & $\begin{array}{l}\text { putative enoyl-CoA hydratase/isomerase [Bordetella } \\
\text { bronchiseptica RB50] }\end{array}$ & NCBI \\
\hline SCESMY2001D06.g & 1 & 616 & $4,00 \mathrm{E}-33$ & $\begin{array}{l}\text { small nuclear ribonucleoprotein F, putative / U6 } \\
\text { snRNA-associated Sm-like protein, putative / Sm } \\
\text { protein F, putative [Arabidopsis thaliana] }\end{array}$ & NCBI \\
\hline SCESMY2001B06.g & 1 & 711 & $7,00 \mathrm{E}-33$ & $\begin{array}{l}\text { COG0667: Predicted oxidoreductases (related to } \\
\text { aryl-alcohol dehydrogenases) [Burkholderia cepacia } \\
\text { R18194] }\end{array}$ & NCBI \\
\hline SCESMY2001D12.g & 1 & 737 & $1,00 \mathrm{E}-31$ & $\begin{array}{l}\text { COG1749: Flagellar hook protein FlgE } \\
\text { [Pseudomonas fluorescens PfO-1] }\end{array}$ & NCBI \\
\hline SCESMY2002E09.g & 1 & 507 & $1,00 \mathrm{E}-31$ & $\begin{array}{l}\text { filamentous hemagglutinin, intein-containing, } \\
\text { putative [Pseudomonas syringae pv. tomato str. } \\
\text { DC3000 }\end{array}$ & NCBI \\
\hline SCESMY2001E09.g & 1 & 395 & $2,00 \mathrm{E}-31$ & $\begin{array}{l}\text { COG2610: } \mathrm{H}+\text { /gluconate symporter and related } \\
\text { permeases [Pseudomonas syringae pv. syringae } \\
\text { B728a] }\end{array}$ & NCBI \\
\hline SCESMY2001E11.g & 1 & 745 & 7,00E-31 & $\begin{array}{l}\text { hypothetical protein [Oryza sativa (japonica } \\
\text { cultivar-group)] }\end{array}$ & NCBI \\
\hline SCESMY2003G11.g & 1 & 740 & $8,00 \mathrm{E}-27$ & $\begin{array}{l}\text { putative regulatory protein [Bordetella pertussis } \\
\text { Tohama I] }\end{array}$ & NCBI \\
\hline SCESMY2001D11.g & 1 & 749 & $7,00 \mathrm{E}-26$ & protein kinase family protein [Arabidopsis thaliana] & NCBI \\
\hline SCESMY2003F03.g & 1 & 732 & $6,00 \mathrm{E}-25$ & $\begin{array}{l}\text { COG4529: Uncharacterized protein conserved in } \\
\text { bacteria [Pseudomonas fluorescens PfO-1] }\end{array}$ & NCBI \\
\hline SCESMY2001C03.g & 1 & 679 & $9,00 \mathrm{E}-24$ & $\begin{array}{l}\text { putative exported protein [Bordetella bronchiseptica } \\
\text { RB50] }\end{array}$ & NCBI \\
\hline SCESMY2001B08.g & 1 & 794 & 2,00E-23 & $\begin{array}{l}\text { predicted CDS, chr415 synaptotagmin like (5M282) } \\
\text { [Caenorhabditis elegans] }\end{array}$ & NCBI \\
\hline SCESMY2003B07.g & 1 & 750 & 1,00E-22 & $\begin{array}{l}\text { hypothetical protein MG06653.4 [Magnaporthe } \\
\text { grisea 70-15] }\end{array}$ & NCBI \\
\hline
\end{tabular}


Anexo 4 - Similaridades entre ESTs expressas em raízes de cana-de-açúcar inoculadas e adubadas com $20 \mathrm{mg} \mathrm{kg}^{-1}$ e seqüências depositadas nos bancos de dados NCBI ou SUCEST. As seqências foram comparadas utilizando-se o algoritmo Blast

(continuação)

\begin{tabular}{|c|c|c|c|c|c|}
\hline Cluster & Read & Tamanho & E-value & Blast & Base \\
\hline SCESMY2001G12.g & 1 & 497 & $1,00 \mathrm{E}-19$ & $\begin{array}{l}\text { possible serine protease homolog [Haemophilus } \\
\text { ducreyi } 35000 \mathrm{HP} \text { ] }\end{array}$ & NCBI \\
\hline SCESMY2003H11.g & 1 & 548 & $9,00 \mathrm{E}-19$ & transcription factor EREBP1 [Oryza sativa] & NCBI \\
\hline SCESMY2002G04.g & 1 & 640 & $3,00 \mathrm{E}-18$ & $\begin{array}{l}\text { hypothetical protein [Oryza sativa (japonica } \\
\text { cultivar-group)] }\end{array}$ & NCBI \\
\hline SCESMY2002A04.g & 1 & 227 & $6,00 \mathrm{E}-18$ & $\begin{array}{l}\text { sulfite reductase (ferredoxin) (EC 1.8.7.1) sir } \\
\text { precursor - maize }\end{array}$ & NCBI \\
\hline SCESMY2003B06.g & 1 & 200 & $8,00 \mathrm{E}-18$ & $\begin{array}{l}\text { COG4191: Signal transduction histidine kinase } \\
\text { regulating C4-dicarboxylate transport system } \\
\text { [Pseudomonas fluorescens PfO-1] }\end{array}$ & NCBI \\
\hline SCESMY2003B02.g & 1 & 653 & $2,00 \mathrm{E}-16$ & $\begin{array}{l}\text { unnamed protein product [Oryza sativa (japonica } \\
\text { cultivar-group)] }\end{array}$ & NCBI \\
\hline SCESMY2003G04.g & 1 & 356 & $2,00 \mathrm{E}-16$ & $\begin{array}{l}\text { polyadenylate-binding protein - wheat } \\
\text { gi|1737492|gb|AAB38974.1| poly(A)-binding } \\
\text { protein [Triticum aestivum] }\end{array}$ & NCBI \\
\hline SCESMY2001C07.g & 1 & 770 & $5,00 \mathrm{E}-13$ & $\begin{array}{l}\text { probable transcriptional regulator [Mesorhizobium } \\
\text { loti MAFF303099] }\end{array}$ & NCBI \\
\hline SCESMY2003C08.g & 1 & 714 & $2,00 \mathrm{E}-12$ & bll0507 [Bradyrhizobium japonicum] & NCBI \\
\hline SCESMY2003G01.g & 1 & 715 & $1,00 \mathrm{E}-11$ & $\begin{array}{l}\text { similar to Dictyostelium discoideum (Slime mold). } \\
\text { Adenylyl cyclase }\end{array}$ & NCBI \\
\hline SCESMY2003E09.g & 1 & 355 & $4,00 \mathrm{E}-11$ & $\begin{array}{l}\text { COG1028: Dehydrogenases with different } \\
\text { specificities (related to short-chain alcohol } \\
\text { dehydrogenases) [Methylobacillus flagellatus KT] }\end{array}$ & NCBI \\
\hline SCESMY2003C07.g & 1 & 693 & $7,00 \mathrm{E}-11$ & $\begin{array}{l}\text { P0039H02.23 [Oryza sativa (japonica cultivar- } \\
\text { group)] }\end{array}$ & NCBI \\
\hline SCESMY2003B09.g & 1 & 365 & $3,00 \mathrm{E}-10$ & $\begin{array}{l}\text { P0691E06.20 [Oryza sativa (japonica cultivar- } \\
\text { group)] }\end{array}$ & NCBI \\
\hline SCESMY2003D10.g & 1 & 677 & 5,00E-09 & $\begin{array}{l}\text { OSJNBb0118P14.9 [Oryza sativa (japonica cultivar- } \\
\text { group)] }\end{array}$ & - NCBI \\
\hline SCESMY2003A02.g & 1 & 491 & $6,00 \mathrm{E}-08$ & $\begin{array}{l}\text { unknown protein [Oryza sativa (japonica cultivar- } \\
\text { group)] }\end{array}$ & NCBI \\
\hline SCESMY2001C09.g & 1 & 247 & $1,00 \mathrm{E}-07$ & 40S ribosomal protein S21 homolog & SUCEST \\
\hline SCESMY2003E08.g & 1 & 452 & $1,00 \mathrm{E}-07$ & $\begin{array}{l}\text { putative gamma-glutamylcysteine synthetase [Zea } \\
\text { mays] }\end{array}$ & NCBI \\
\hline SCESMY2003A07.g & 1 & 228 & $4,00 \mathrm{E}-07$ & $\begin{array}{l}\text { putative short chain alcohol dehydrogenase [Oryza } \\
\text { sativa (japonica cultivar-group)] }\end{array}$ & NCBI \\
\hline SCESMY2002C10.g & 1 & 668 & 3,00E-05 & $\begin{array}{l}\text { (AB026500) ethylene receptor CS-ETR2 [Cucumis } \\
\text { sativus] }\end{array}$ & SUCEST \\
\hline SCESMY2001E05.g & 1 & 333 & $7,00 \mathrm{E}-04$ & $\begin{array}{l}\text { far upstream element-binding protein (Homo } \\
\text { sapiens) }\end{array}$ & SUCEST \\
\hline SCESMY2001E02.g & 1 & 369 & $1,00 \mathrm{E}-03$ & dTDP-glucose 4-6-dehydratase homolog D18 & SUCEST \\
\hline SCESMY2001D09.g & 1 & 720 & $7,00 \mathrm{E}-03$ & serine/threonine kinase-like protein & SUCEST \\
\hline SCESMY2003H09.g & 1 & 721 & $9,00 \mathrm{E}-03$ & GRAB2 protein [Triticum sp.] & SUCEST \\
\hline SCESMY2002E04.g & 1 & 696 & $1,20 \mathrm{E}-02$ & cluster sem notação & SUCEST \\
\hline SCESMY2003G03.g & 1 & 267 & $1,50 \mathrm{E}-02$ & proline-rich kinase & SUCEST \\
\hline
\end{tabular}


Anexo 4. Similaridades entre ESTs expressas em raízes de cana-de-açúcar inoculadas e adubadas com $20 \mathrm{mg} \mathrm{kg}^{-1}$ e seqüências depositadas nos bancos de dados NCBI ou SUCEST. As seqências foram comparadas utilizando-se o algoritmo Blast

(conclusão)

\begin{tabular}{lcccll}
\hline Cluster & Read & Tamanho & E-value & Blast & Base \\
\hline SCESMY2003E07.g & 1 & 688 & $2,90 E-01$ & WD-repeat protein-like & SUCEST \\
SCESMY2003D03.g & 1 & 171 & $3,60 E-01$ & auxin-regulated protein (IAA8) & SUCEST \\
SCESMY2002E01.g & 1 & 747 & $4,40 E-01$ & (AP001800) hypothetical protein [Oryza sativa] & SUCEST \\
SCESMY2002H09.g & 1 & 369 & $1,60 E+00$ & 30S ribosomal protein S8 & SUCEST \\
SCESMY2001H08.g & 1 & 707 & $2,00 E+00$ & cluster sem notação & SUCEST \\
\hline
\end{tabular}


Anexo 5. Similaridades de ESTs obtidas a partir de raízes de cana-de-açúcar não-inoculadas e adubadas 200mg $\mathrm{P} \mathrm{kg}^{-1}$ com os bancos de dados NCBI ou SUCEST.

(continua)

\begin{tabular}{|c|c|c|c|c|c|}
\hline Cluster & Read & Tamanho & E-value & Blast & Base \\
\hline SCESMY3006H06.g & 3 & 748 & 6,00E-33 & Catalase isozyme 3 & NCBI \\
\hline SCESMY3005B05.g & 2 & 481 & $4,00 \mathrm{E}-14$ & histone H3.2 & NCBI \\
\hline SCESMY3004F06.g & 1 & 736 & $1,00 \mathrm{E}-157$ & putative extensin & SUCEST \\
\hline SCESMY3005F09.g & 1 & 475 & $1,00 \mathrm{E}-97$ & putative poly(A) polymerase & SUCEST \\
\hline SCESMY3003A12.g & 1 & 556 & 2,00E-96 & Cluster sem notação & SUCEST \\
\hline SCESMY3003C03.g & 1 & 525 & 2,00E-90 & $\begin{array}{l}\text { anthranilate phosphoribosyltransferase-like } \\
\text { protein }\end{array}$ & SUCEST \\
\hline SCESMY3004D03.g & 1 & 750 & 3,00E-76 & $\begin{array}{l}\text { P0003E08.1 [Oryza sativa (japonica cultivar- } \\
\text { group)] }\end{array}$ & NCBI \\
\hline SCESMY3005C07.g & 1 & 461 & $6,00 \mathrm{E}-76$ & cyclophylin -like protein & SUCEST \\
\hline SCESMY3006B02.g & 1 & 565 & $7,00 \mathrm{E}-71$ & $\begin{array}{l}\text { OSJNBa0094O15.3 [Oryza sativa (japonica } \\
\text { cultivar-group)] }\end{array}$ & NCBI \\
\hline SCESMY3002B07.g & 1 & 349 & $2,00 \mathrm{E}-70$ & $\begin{array}{l}\text { (AB007727) dihydropyrimidinase } \\
\text { [Arabidopsis thaliana]" }\end{array}$ & SUCEST \\
\hline SCESMY3002F12.g & 1 & 467 & 2,00E-68 & aldehyde oxidase & SUCEST \\
\hline SCESMY3004C11.g & 1 & 654 & $5,00 \mathrm{E}-67$ & $\begin{array}{l}\text { citrate synthase, glyoxysomal, putative } \\
\text { [Arabidopsis thaliana] }\end{array}$ & NCBI \\
\hline SCESMY3006D12.g & 1 & 354 & 2,00E-59 & Cluster sem notação & SUCEST \\
\hline SCESMY3003B06.g & 1 & 344 & $4,00 \mathrm{E}-57$ & Cluster sem notação & SUCEST \\
\hline SCESMY3005E01.g & 1 & 299 & 1,00E-56 & Cluster sem notação & SUCEST \\
\hline SCESMY3003H02.g & 1 & 621 & 3,00E-51 & DnaJ protein homolog ZMDJ1 - maize & NCBI \\
\hline SCESMY3002C07.g & 1 & 343 & $1,00 \mathrm{E}-46$ & $\begin{array}{l}\text { putative pyrrolidone carboxyl peptidase [Oryza } \\
\text { sativa] }\end{array}$ & SUCEST \\
\hline SCESMY3003C06.g & 1 & 647 & $1,00 \mathrm{E}-40$ & RNA-binding protein & NCBI \\
\hline SCESMY3005F02.g & 1 & 331 & $7,00 \mathrm{E}-40$ & putative Clp protease [Oryza sativa]" & SUCEST \\
\hline SCESMY3002G02.g & 1 & 389 & $7,00 \mathrm{E}-38$ & Cluster sem notação & SUCEST \\
\hline SCESMY3002B02.g & 1 & 362 & 1,00E-35 & $\begin{array}{l}\text { (AC008007) F12M16.22 [Arabidopsis } \\
\text { thaliana] }\end{array}$ & SUCEST \\
\hline SCESMY3005F06.g & 1 & 166 & 1,00E-35 & $\begin{array}{l}\text { putative nitrilase-associated protein Alternative } \\
\text { splicing exists based on EST evidence }\end{array}$ & SUCEST \\
\hline SCESMY3006A08.g & 1 & 666 & $6,00 \mathrm{E}-34$ & $\begin{array}{l}\text { putative pre-mRNA splicing factor SF2 [Oryza } \\
\text { sativa (japonica cultivar-group)] }\end{array}$ & NCBI \\
\hline SCESMY3003F08.g & 1 & 164 & $1,00 \mathrm{E}-31$ & Cluster sem notação & SUCEST \\
\hline SCESMY3004D02.g & 1 & 696 & $1,00 \mathrm{E}-30$ & $\begin{array}{l}\text { putative } 40 \text { S ribosomal protein S26 [Oryza } \\
\text { sativa (japonica cultivar-group)] }\end{array}$ & NCBI \\
\hline SCESMY3004A06.g & 1 & 630 & $7,00 \mathrm{E}-28$ & $\begin{array}{l}\text { pathogenesis-related protein-like protein } \\
\text { [Oryza sativa (japonica cultivar-group)] }\end{array}$ & NCBI \\
\hline SCESMY3005D05.g & 1 & 211 & $1,00 \mathrm{E}-27$ & sucrose synthase -like protein & SUCEST \\
\hline SCESMY3005D08.g & 1 & 401 & $1,00 \mathrm{E}-25$ & $\begin{array}{l}\text { P0638D12.11 [Oryza sativa (japonica cultivar- } \\
\text { group)] }\end{array}$ & NCBI \\
\hline SCESMY3005G06.g & 1 & 210 & $2,00 \mathrm{E}-25$ & $\begin{array}{l}\text { putative dolichyl-phosphate beta- } \\
\text { glucosyltransferase }\end{array}$ & SUCEST \\
\hline
\end{tabular}


Anexo 5. Similaridades de ESTs obtidas a partir de raízes de cana-de-açúcar não-inoculadas e adubadas 200 $\mathrm{mg} \mathrm{P} \mathrm{kg}^{-1}$ com os bancos de dados NCBI ou SUCEST.

(conclusão)

\begin{tabular}{|c|c|c|c|c|c|}
\hline Cluster & Read & Tamanho & E-value & Blast & Base \\
\hline SCESMY3004G12.g & 1 & 170 & $3,00 \mathrm{E}-25$ & mucin 2, intestinal & SUCEST \\
\hline SCESMY3003C12.g & 1 & 416 & $1,00 \mathrm{E}-24$ & 60S RIBOSOMAL PROTEIN L39 & NCBI \\
\hline SCESMY3005C04.g & 1 & 162 & $4,00 \mathrm{E}-24$ & Unknown protein & SUCEST \\
\hline SCESMY3005D04.g & 1 & 299 & 4,00E-24 & $\begin{array}{l}\text { dbj|BAA85447.1| (AP000616) EST } \\
\text { C72179(E1153) corresponds to a region of the } \\
\text { predicted gene }\end{array}$ & SUCEST \\
\hline SCESMY3004E06.g & 1 & 497 & $9,00 \mathrm{E}-19$ & $\begin{array}{l}\text { OSJNBa0041A02.7 [Oryza sativa (japonica } \\
\text { cultivar-group)] }\end{array}$ & NCBI \\
\hline SCESMY3002C10.g & 1 & 552 & $1,00 \mathrm{E}-18$ & MADS box protein 1 [Zea mays] & NCBI \\
\hline SCESMY3005G03.g & 1 & 491 & 2,00E-18 & $\begin{array}{l}\text { putative translation initiation factor [Oryza } \\
\text { sativa] }\end{array}$ & NCBI \\
\hline SCESMY3002D07.g & 1 & 534 & $3,00 \mathrm{E}-18$ & $\begin{array}{l}\text { Vacuolar ATP synthase } 16 \mathrm{kDa} \text { proteolipid } \\
\text { subunit }\end{array}$ & NCBI \\
\hline SCESMY3003F01.g & 1 & 578 & $4,00 \mathrm{E}-17$ & avirulence-responsive protein, putative & NCBI \\
\hline SCESMY3004H12.g & 1 & 411 & $2,00 \mathrm{E}-15$ & clathrin coat assembly protein [Oryz & NCBI \\
\hline SCESMY3004H04.g & 1 & 700 & $2,00 \mathrm{E}-12$ & $\begin{array}{l}\text { putative serine/threonine kinase [Hordeum } \\
\text { vulgare] }\end{array}$ & NCBI \\
\hline SCESMY3005D02.g & 1 & 351 & $8,00 \mathrm{E}-10$ & $\begin{array}{l}\text { P0490D09.24 [Oryza sativa (japonica cultivar- } \\
\text { group)] }\end{array}$ & NCBI \\
\hline SCESMY3005A09.g & 1 & 361 & 7,00E-09 & $\begin{array}{l}\text { calcium-binding EF hand family protein } \\
\text { [Arabidopsis thaliana] }\end{array}$ & NCBI \\
\hline SCESMY3003D03.g & 1 & 477 & $1,00 \mathrm{E}-07$ & plastid sigma factor $2 \mathrm{~A}$ & NCBI \\
\hline SCESMY3003G11.g & 1 & 481 & 4,00E-07 & $\begin{array}{l}\text { CIPK-like protein [Oryza sativa (japonica } \\
\text { cultivar-group)] }\end{array}$ & SUCEST \\
\hline SCESMY3005H12.g & 1 & 274 & $9,00 \mathrm{E}-07$ & $\begin{array}{l}\text { putative cytochrome B5 [Oryza sativa } \\
\text { (japonica cultivar-group)] }\end{array}$ & NCBI \\
\hline SCESMY3004E05.g & 1 & 377 & 2,00E-06 & $\begin{array}{l}\text { s-adenosylmethinonine synthetase [Camellia } \\
\text { sinensis] }\end{array}$ & NCBI \\
\hline SCESMY3004D07.g & 1 & 559 & 1,60E-02 & NAM-like protein [Arabidopsis thaliana] & SUCEST \\
\hline SCESMY3004B06.g & 1 & 186 & 2,30E-02 & Cluster sem notação & SUCEST \\
\hline SCESMY3003H09.g & 1 & 569 & E-02 & Clust & SUCEST \\
\hline SCESMY3003B01.g & 1 & 216 & $6,50 \mathrm{E}-02$ & Unknown protein & SUCEST \\
\hline SCESMY3002A04.g & 1 & 191 & 2,30E-01 & $\begin{array}{l}\text { small nuclear ribonucleoprotein, Sm D3 } \\
\text { (Homo sapiens) }\end{array}$ & SUCEST \\
\hline SCESMY3004C10.g & 1 & 158 & $1,20 \mathrm{E}+00$ & Cluster sem notação & SUCEST \\
\hline
\end{tabular}


Anexo 6 - Similaridades de ESTs obtidas a partir de raízes de cana-de-açúcar não-inoculadas e adubadas 200mg $\mathrm{P} \mathrm{kg}^{-1}$ com os bancos de dados NCBI ou SUCEST.

(continua)

\begin{tabular}{|c|c|c|c|c|c|}
\hline Cluster & Read & Tamanho & E-value & Blast & Base \\
\hline SCESMY4001A04.g & 1 & 614 & 2,00E-94 & $\begin{array}{l}\text { TBA1_ELEIN TUBULIN ALPHA-1 CHAIN } \\
\text { (ALPHA-TUBULIN 1) }\end{array}$ & SUCEST \\
\hline SCESMY4001A07.g & 1 & 643 & $1,00 \mathrm{E}-92$ & $\begin{array}{l}\text { similar to unknown protein [Arabidopsis } \\
\text { thaliana] }\end{array}$ & SUCEST \\
\hline SCESMY4001B01.g & 1 & 561 & $1,00 \mathrm{E}-114$ & $\begin{array}{l}\text { Acyl-CoA dehydrogenases [Pseudomonas } \\
\text { fluorescens PfO-1] }\end{array}$ & NCBI \\
\hline SCESMY4001B04.g & 1 & 614 & $7,00 \mathrm{E}-84$ & $\begin{array}{l}\text { putative aldo/keto reductase family protein } \\
\text { [Oryza sativa (japonica cultivar-group)] }\end{array}$ & NCBI \\
\hline SCESMY4001B05.g & 1 & 657 & $1,00 \mathrm{E}-108$ & $\begin{array}{l}\text { succinyl-CoA synthetase, alpha chain } \\
\text { [Bordetella pertussis Tohama I] }\end{array}$ & NCBI \\
\hline SCESMY4001B07.g & 1 & 646 & 4,00E-83 & $\begin{array}{l}\text { mitogen-activated protein kinase MMK2 (EC } \\
\text { 2.7.1.-) - alfalfa }\end{array}$ & SUCEST \\
\hline SCESMY4001C04.g & 1 & 629 & 8,00E-83 & $\begin{array}{l}\text { similar to unknown protein [Arabidopsis } \\
\text { thaliana] }\end{array}$ & SUCEST \\
\hline SCESMY4001C06.g & 1 & 651 & $1,00 \mathrm{E}-108$ & $\begin{array}{l}\text { diaminobutyrate--pyruvate aminotransferase } \\
\text { [Bordetella parapertussis 12822] }\end{array}$ & NCBI \\
\hline SCESMY4001C07.g & 1 & 647 & $1,00 \mathrm{E}-104$ & $\begin{array}{l}\text { PROBABLE TRANSCRIPTION REGULATOR } \\
\text { PROTEIN [Ralstonia solanacearum GMI1000] }\end{array}$ & NCBI \\
\hline SCESMY4001D01.g & 1 & 533 & $1,00 \mathrm{E}-102$ & $\begin{array}{l}\text { Aspartate/tyrosine/aromatic aminotransferase } \\
\text { [Pseudomonas fluorescens PfO-1] }\end{array}$ & NCBI \\
\hline SCESMY4001D03.g & 1 & 308 & 6,00E-99 & $\begin{array}{l}\text { Outer membrane receptor proteins, mostly Fe } \\
\text { transport [Pseudomonas aeruginosa }\end{array}$ & NCBI \\
\hline SCESMY4001D07.g & 1 & 474 & 8,00E-82 & $\begin{array}{l}\text { similar to putative reverse transcriptase } \\
\text { (AC005315) [Oryza sativa] }\end{array}$ & SUCEST \\
\hline SCESMY4001E03.g & 1 & 376 & 6,00E-95 & $\begin{array}{l}\mathrm{H}+\text { /gluconate symporter and related permeases } \\
\text { [Pseudomonas syringae pv. syringae B728a] }\end{array}$ & NCBI \\
\hline SCESMY4001E04.g & 1 & 657 & 4,00E-93 & $\begin{array}{l}\text { Ketopantoate reductase [Pseudomonas } \\
\text { fluorescens PfO-1] }\end{array}$ & NCBI \\
\hline SCESMY4001E06.g & 1 & 634 & 2,00E-91 & $\begin{array}{l}\text { argininosuccinate lyase [Bordetella parapertussis } \\
12822 \text { ] }\end{array}$ & NCBI \\
\hline SCESMY4001F06.g & 2 & 441 & $1,00 \mathrm{E}-115$ & $\begin{array}{l}\text { Signal transduction histidine kinase regulating } \\
\text { C4-dicarboxylate transport system } \\
\text { [Pseudomonas fluorescens PfO-1] }\end{array}$ & NCBI \\
\hline SCESMY4001G03.g & 1 & 661 & 5,00E-90 & $\begin{array}{l}\text { Osmosensitive K+ channel histidine kinase } \\
\text { [Pseudomonas fluorescens PfO-1] }\end{array}$ & NCBI \\
\hline SCESMY4001G04.g & 1 & 636 & 3,00E-86 & $\begin{array}{l}\text { Flagellar basal body rod protein [Pseudomonas } \\
\text { fluorescens PfO-1] }\end{array}$ & NCBI \\
\hline SCESMY4001G05.g & 1 & 626 & $1,00 \mathrm{E}-81$ & $\begin{array}{l}\text { D-isomer specific 2-hydroxyacid dehydrogenase } \\
\text { family protein [Pseudomonas putida KT2440] }\end{array}$ & NCBI \\
\hline SCESMY4001G06.g & 1 & 691 & $1,00 \mathrm{E}-74$ & $\begin{array}{l}\text { HMDH_MAIZE 3-HYDROXY-3- } \\
\text { METHYLGLUTARYL-COENZYME A } \\
\text { REDUCTASE (HMG-COA REDUCTASE) }\end{array}$ & SUCEST \\
\hline SCESMY4001H05.g & 1 & 580 & $4,00 \mathrm{E}-78$ & $\begin{array}{l}\text { Signal transduction histidine kinase } \\
\text { [Microbulbifer degradans 2-40] }\end{array}$ & NCBI \\
\hline SCESMY4001H06.g & 1 & 665 & $1,00 \mathrm{E}-76$ & $\begin{array}{l}\text { transcriptional regulator, LysR family } \\
\text { [Pseudomonas syringae pv. tomato str. DC3000] }\end{array}$ & NCBI \\
\hline SCESMY4001H07.g & 1 & 671 & 2,00E-76 & $\begin{array}{l}\text { conserved hypothetical protein [Pseudomonas } \\
\text { syringae pv. tomato str. DC3000] }\end{array}$ & NCBI \\
\hline
\end{tabular}


Anexo 6 - Similaridades de ESTs obtidas a partir de raízes de cana-de-açúcar não-inoculadas e adubadas 200mg $\mathrm{P} \mathrm{kg}^{-1}$ com os bancos de dados NCBI ou SUCEST.

(continuação)

\begin{tabular}{|c|c|c|c|c|c|}
\hline Cluster & Read & Tamanho & E-value & Blast & Base \\
\hline SCESMY4002A02.g & 1 & 559 & 7,00E-73 & $\begin{array}{l}\text { putative beta-1,3-glucanase [Arabidopsis } \\
\text { thaliana] }\end{array}$ & SUCEST \\
\hline SCESMY4002A06.g & 1 & 558 & $5,00 \mathrm{E}-73$ & $\begin{array}{l}\text { Uncharacterized protein conserved in bacteria } \\
\text { [Ralstonia eutropha JMP134] }\end{array}$ & NCBI \\
\hline SCESMY4002A07.g & 1 & 796 & $1,00 \mathrm{E}-70$ & cluster sem notação & SUCEST \\
\hline SCESMY4002A09.g & 1 & 825 & $5,00 \mathrm{E}-70$ & $\begin{array}{l}\text { hypothetical protein F27K19.140 - Arabidopsis } \\
\text { thaliana }\end{array}$ & SUCEST \\
\hline SCESMY4002A10.g & 1 & 685 & $5,00 \mathrm{E}-70$ & $\begin{array}{l}\text { Similar to copia-type pol polyprotein. } \\
\text { (AF105716) [Oryza sativa] }\end{array}$ & SUCEST \\
\hline SCESMY4002A11.g & 1 & 631 & 1,00E-67 & $\begin{array}{l}\text { Imidazolonepropionase (Imidazolone-5- } \\
\text { propionate hydrolase) }\end{array}$ & NCBI \\
\hline SCESMY4002A12.g & 1 & 463 & 3,00E-72 & $\begin{array}{l}\text { hydrolase (HAD superfamily) [Bacillus cereus } \\
\text { ATCC 14579] }\end{array}$ & NCBI \\
\hline SCESMY4002B02.g & 2 & 639 & 5,00E-95 & $\begin{array}{l}\text { hypothetical protein T10P11.3.2 - Arabidopsis } \\
\text { thaliana }\end{array}$ & SUCEST \\
\hline SCESMY4002B03.g & 1 & 500 & $2,00 \mathrm{E}-64$ & cluster sem notação & SUCEST \\
\hline SCESMY4002B04.g & 1 & 558 & 2,00E-59 & $\begin{array}{l}\text { putative pyrophosphate-dependent } \\
\text { phosphofructo-1-kinase [Oryza sativa] }\end{array}$ & SUCEST \\
\hline SCESMY4002B05.g & 1 & 817 & 4,00E-69 & $\begin{array}{l}\text { Anaerobic dehydrogenases, typically } \\
\text { selenocysteine-containing [Pseudomonas } \\
\text { fluorescens PfO-1] }\end{array}$ & NCBI \\
\hline SCESMY4002B07.g & 1 & 249 & 4,00E-69 & $\begin{array}{l}\text { putative periplasmic substrate-binding transport } \\
\text { protein [Yersinia pestis] }\end{array}$ & NCBI \\
\hline SCESMY4002B08.g & 1 & 755 & 2,00E-46 & $\begin{array}{l}\text { hypothetical protein T10D17.10 - Arabidopsis } \\
\text { thaliana }\end{array}$ & SUCEST \\
\hline SCESMY4002B10.g & 1 & 744 & 1,00E-67 & $\begin{array}{l}\text { NADH:flavin oxidoreductases, Old Yellow } \\
\text { Enzyme family [Pseudomonas fluorescens PfO- } \\
\text { 1] }\end{array}$ & NCBI \\
\hline SCESMY4002B11.g & 1 & 744 & 9,00E-38 & $\begin{array}{l}\text { 12-oxophytodienoate reductase } 3 \text { [Lycopersicon } \\
\text { esculentum }\end{array}$ & SUCEST \\
\hline SCESMY4002B12.g & 1 & 475 & $1,00 \mathrm{E}-29$ & cluster sem notação & SUCEST \\
\hline SCESMY4002C01.g & 1 & 508 & 2,00E-64 & $\begin{array}{l}\text { GlnQ [Mycobacterium avium subsp. } \\
\text { paratuberculosis str. k10] }\end{array}$ & NCBI \\
\hline SCESMY4002C02.g & 1 & 401 & $5,00 \mathrm{E}-29$ & glycine-rich protein grp3 - maize & SUCEST \\
\hline SCESMY4002C03.g & 1 & 583 & $1,00 \mathrm{E}-23$ & $\begin{array}{l}\text { Membrane carboxypeptidase (penicillin-binding } \\
\text { protein) [Pseudomonas fluorescens PfO-1] }\end{array}$ & NCBI \\
\hline SCESMY4002C04.g & 1 & 740 & $1,00 \mathrm{E}-23$ & $\begin{array}{l}\text { anaerobically inducible early gene } 2 \text { [Oryza } \\
\text { sativa] }\end{array}$ & SUCEST \\
\hline SCESMY4002C05.g & 1 & 653 & 6,00E-61 & $\begin{array}{l}\text { unnamed protein product [Photorhabdus } \\
\text { luminescens subsp. laumondii TTO1] }\end{array}$ & NCBI \\
\hline SCESMY4002C06.g & 1 & 771 & 1,00E-20 & $\begin{array}{l}\text { ABC-type nitrate/sulfonate/bicarbonate transport } \\
\text { systems, periplasmic components }\end{array}$ & NCBI \\
\hline SCESMY4002C07.g & 1 & 747 & $9,00 \mathrm{E}-56$ & $\begin{array}{l}\text { Uncharacterized protein conserved in bacteria } \\
\text { [Pseudomonas fluorescens PfO-1] }\end{array}$ & NCBI \\
\hline SCESMY4002C08.g & 1 & 795 & 1,00E-20 & $\begin{array}{l}\text { putative CTR1-like kinase kinase kinase [Oryza } \\
\text { sativa (japonica cultivar-group)] }\end{array}$ & NCBI \\
\hline SCESMY4002C12.g & 1 & 297 & 2,00E-20 & homeotic protein BEL1 - Arabidopsis thaliana & SUCEST \\
\hline
\end{tabular}


Anexo 6 - Similaridades de ESTs obtidas a partir de raízes de cana-de-açúcar não-inoculadas e adubadas 200mg $\mathrm{P} \mathrm{kg}^{-1}$ com os bancos de dados NCBI ou SUCEST.

(continuação)

\begin{tabular}{|c|c|c|c|c|c|}
\hline Cluster & Read & Tamanho & E-value & Blast & Base \\
\hline SCESMY4002D02.g & 1 & 679 & $4,00 \mathrm{E}-53$ & $\begin{array}{l}\text { hypothetical protein PA2075 [Pseudomonas } \\
\text { aeruginosa PAO1] }\end{array}$ & NCBI \\
\hline SCESMY4002D03.g & 1 & 776 & $4,00 \mathrm{E}-18$ & unknown protein [Arabidopsis thaliana] & SUCEST \\
\hline SCESMY4002D05.g & 1 & 733 & $1,00 \mathrm{E}-51$ & $\begin{array}{l}\text { sugar epimerase BlmG [Streptomyces } \\
\text { verticillus] }\end{array}$ & SUCEST \\
\hline SCESMY4002D07.g & 1 & 743 & 2,00E-11 & elongation factor 1-alpha [Zea mays] & SUCEST \\
\hline SCESMY4002D08.g & 1 & 474 & 1,00E-05 & $\begin{array}{l}\text { PROBABLE D-SERINE DEAMINASE (D- } \\
\text { SERINE DEHYDRATASE) PROTEIN }\end{array}$ & NCBI \\
\hline SCESMY4002D09.g & 1 & 699 & 2,00E-05 & $\begin{array}{l}\text { endoxyloglucan transferase, putative } \\
\text { [Arabidopsis thaliana] }\end{array}$ & SUCEST \\
\hline SCESMY4002D10.g & 1 & 647 & 8,00E-05 & $\begin{array}{l}\text { MAIZE ADP,ATP CARRIER PROTEIN } 2 \\
\text { PRECURSOR }\end{array}$ & SUCEST \\
\hline SCESMY4002D12.g & 1 & 498 & 5,00E-04 & $\begin{array}{l}\text { beta-glucosidase aggregating factor precursor } \\
\text { [Zea mays] }\end{array}$ & SUCEST \\
\hline SCESMY4002E02.g & 1 & 369 & $5,00 \mathrm{E}-45$ & $\begin{array}{l}\text { Outer membrane receptor proteins, mostly Fe } \\
\text { transport [Pseudomonas aeruginosa }\end{array}$ & NCBI \\
\hline SCESMY4002E03.g & 1 & 499 & 7,00E-04 & $\begin{array}{l}\text { ER1_HEVBR ETHYLENE-INDUCIBLE } \\
\text { PROTEIN HEVER }\end{array}$ & SUCEST \\
\hline SCESMY4002E04.g & 1 & 625 & 0,013 & $\begin{array}{l}\text { contains similarity to DsPTP1 } \\
\text { protein gene_id:MQM1.1 [Arabidopsis } \\
\text { thaliana] }\end{array}$ & SUCEST \\
\hline SCESMY4002E05.g & 1 & 300 & $5,00 \mathrm{E}-42$ & $\begin{array}{l}\text { Signal transduction histidine kinase } \\
\text { [Pseudomonas fluorescens PfO-1] }\end{array}$ & NCBI \\
\hline SCESMY4002E07.g & 1 & 838 & $1,00 \mathrm{E}-100$ & elongation factor EF-2 [Arabidopsis thaliana] & SUCEST \\
\hline SCESMY4002E09.g & 1 & 530 & $2,00 \mathrm{E}-39$ & $\begin{array}{l}\text { hypothetical protein TdenA01000104 } \\
\text { [Thiobacillus denitrificans }\end{array}$ & NCBI \\
\hline SCESMY4002E10.g & 1 & 410 & $1,00 \mathrm{E}-101$ & $\begin{array}{l}\text { Similar to Arabidopsis thaliana gamma-adaptin } 1 \\
\text { mRNA, complete cds. }\end{array}$ & SUCEST \\
\hline SCESMY4002E11.g & 1 & 649 & $4,00 \mathrm{E}-39$ & $\begin{array}{l}\text { ABC-type branched-chain amino acid transport } \\
\text { systems, periplasmic component } \\
\text { [Dechloromonas aromatica RCB] }\end{array}$ & NCBI \\
\hline SCESMY4002F02.g & 1 & 528 & $1,00 \mathrm{E}-105$ & $\begin{array}{l}\text { similar to unknown protein [Arabidopsis } \\
\text { thaliana] }\end{array}$ & SUCEST \\
\hline SCESMY4002F04.g & 1 & 650 & 7,00E-38 & BhuT [Bordetella avium] & NCBI \\
\hline SCESMY4002F06.g & 1 & 686 & $1,00 \mathrm{E}-37$ & $\begin{array}{l}\text { major facilitator family transporter } \\
\text { [Pseudomonas putida KT2440] }\end{array}$ & NCBI \\
\hline SCESMY4002F08.g & 1 & 695 & 4,00E-37 & $\begin{array}{l}\text { Ethanolamine ammonia-lyase, large subunit } \\
\text { [Pseudomonas fluorescens PfO-1] }\end{array}$ & NCBI \\
\hline SCESMY4002G02.g & 1 & 513 & $1,00 \mathrm{E}-105$ & $\begin{array}{l}\text { TPIC_SECCE TRIOSEPHOSPHATE } \\
\text { ISOMERASE, CHLOROPLAST PRECURSOR } \\
\text { (TIM) }\end{array}$ & SUCEST \\
\hline SCESMY4002G03.g & 1 & 766 & $1,00 \mathrm{E}-110$ & $\begin{array}{l}\text { similar to unknown protein [Arabidopsis } \\
\text { thaliana] }\end{array}$ & SUCEST \\
\hline SCESMY4002G05.g & 1 & 620 & $1,00 \mathrm{E}-111$ & unknown protein [Oryza sativa] & SUCEST \\
\hline SCESMY4002G07.g & 1 & 656 & 4,00E-35 & $\begin{array}{l}\text { putative pyruvate ferredoxin/flavodoxin } \\
\text { oxidoreductase [Bordetella parapertussis }\end{array}$ & NCBI \\
\hline
\end{tabular}


Anexo 6 - Similaridades de ESTs obtidas a partir de raízes de cana-de-açúcar não-inoculadas e adubadas 200mg $\mathrm{P} \mathrm{kg}^{-1}$ com os bancos de dados NCBI ou SUCEST.

(continuação)

\begin{tabular}{|c|c|c|c|c|c|}
\hline Cluster & Read & Tamanho & E-value & Blast & Base \\
\hline SCESMY4002G08.g & 1 & 786 & $2,00 \mathrm{E}-31$ & $\begin{array}{l}\text { Flp pilus assembly protein, ATPase CpaE } \\
\text { [Pseudomonas fluorescens PfO-1] }\end{array}$ & NCBI \\
\hline SCESMY4002H01.g & 1 & 599 & $1,00 \mathrm{E}-116$ & RNA polymerase alpha subunit [Zea mays] & SUCEST \\
\hline SCESMY4002H05.g & 1 & 637 & $1,00 \mathrm{E}-119$ & protein - Arabidopsis thaliana (fragment) & SUCEST \\
\hline SCESMY4002H06.g & 1 & 737 & $1,00 \mathrm{E}-119$ & $\begin{array}{l}\text { cellulose synthase homolog T26B15.10 - } \\
\text { Arabidopsis thaliana }\end{array}$ & SUCEST \\
\hline SCESMY4002H08.g & 1 & 696 & $7,00 \mathrm{E}-31$ & $\begin{array}{l}\text { Signal transduction histidine kinase regulating } \\
\text { C4-dicarboxylate transport system } \\
\text { [Pseudomonas fluorescens PfO-1] }\end{array}$ & NCBI \\
\hline SCESMY4003A01.g & 1 & 494 & $5,00 \mathrm{E}-29$ & $\begin{array}{l}\text { putative ABC transport permease [Bordetella } \\
\text { parapertussis 12822] }\end{array}$ & NCBI \\
\hline SCESMY4003A03.g & 1 & 735 & $8,00 \mathrm{E}-29$ & $\begin{array}{l}\text { hypothetical protein UM00870.1 [Ustilago } \\
\text { maydis 521] }\end{array}$ & NCBI \\
\hline SCESMY4003A04.g & 1 & 597 & $1,00 \mathrm{E}-121$ & $\begin{array}{l}\text { tetratricopeptide repeat(TPR)-containing protein- } \\
\text { like [Oryza sativa }\end{array}$ & NCBI \\
\hline SCESMY4003A05.g & 1 & 700 & $1,00 \mathrm{E}-126$ & $\begin{array}{l}\text { polynucleotide adenylyltransferase homolog } \\
\text { T16I18.60 - Arabidopsis thaliana }\end{array}$ & SUCEST \\
\hline SCESMY4003B02.g & 1 & 655 & $1,00 \mathrm{E}-126$ & hypothetical protein [Arabidopsis thaliana] & SUCEST \\
\hline SCESMY4003B03.g & 1 & 331 & $5,00 \mathrm{E}-27$ & $\begin{array}{l}\text { Transcriptional regulators containing a DNA- } \\
\text { binding HTH domain and an aminotransferase } \\
\text { domain (MocR family) and their eukaryotic } \\
\text { orthologs [Ralstonia metallidurans }\end{array}$ & NCBI \\
\hline SCESMY4003B05.g & 1 & 666 & $1,00 \mathrm{E}-127$ & unknown protein [Arabidopsis thaliana] & SUCEST \\
\hline SCESMY4003B06.g & 1 & 584 & $7,00 \mathrm{E}-25$ & $\begin{array}{l}\text { Acetyl-CoA acetyltransferase [Ralstonia } \\
\text { eutropha JMP134] }\end{array}$ & NCBI \\
\hline SCESMY4003C01.g & 1 & 342 & $1,00 \mathrm{E}-129$ & $\begin{array}{l}\text { ORYSA METALLOTHIONEIN-LIKE } \\
\text { PROTEIN TYPE } 1\end{array}$ & SUCEST \\
\hline SCESMY4003C02.g & 1 & 719 & $1,00 \mathrm{E}-133$ & scarecrow-like 1 [Arabidopsis thaliana] & SUCEST \\
\hline SCESMY4003C03.g & 1 & 750 & $2,00 \mathrm{E}-21$ & ArgA [Pseudomonas syringae pv. syringae] & NCBI \\
\hline SCESMY4003C05.g & 1 & 712 & $1,00 \mathrm{E}-139$ & $\begin{array}{l}\text { hypothetical protein b1956 [Escherichia coli } \\
\text { K12] }\end{array}$ & NCBI \\
\hline SCESMY4003C06.g & 1 & 493 & $1,00 \mathrm{E}-140$ & $\begin{array}{l}\text { MAIZE TRIOSE PHOSPHATE/PHOSPHATE } \\
\text { TRANSLOCATOR, CHLOROPLAST } \\
\text { PRECURSOR }\end{array}$ & SUCEST \\
\hline SCESMY4003D01.g & 1 & 200 & 2,00E-19 & $\begin{array}{l}\text { ubiquinone/menaquinone biosynthesis } \\
\text { methyltransferase [Shigella flexneri 2a str. } \\
\text { 2457T] }\end{array}$ & NCBI \\
\hline SCESMY4003D02.g & 1 & 506 & $3,00 \mathrm{E}-15$ & $\begin{array}{l}\text { sulfate ABC transporter, periplasmic sulfate- } \\
\text { binding protein [Pseudomonas putida KT2440] }\end{array}$ & NCBI \\
\hline SCESMY4003D03.g & 1 & 776 & $1,00 \mathrm{E}-141$ & $\begin{array}{l}\text { strong similarity to unknown protein } \\
\text { [Arabidopsis thaliana]" }\end{array}$ & SUCEST \\
\hline SCESMY4003D04.g & 1 & 575 & $2,00 \mathrm{E}-14$ & $\begin{array}{l}\text { Collagenase and related proteases [Pseudomonas } \\
\text { fluorescens PfO-1] }\end{array}$ & NCBI \\
\hline SCESMY4003D05.g & 2 & 679 & $6,00 \mathrm{E}-98$ & cluster sem notação & SUCEST \\
\hline SCESMY4003D06.g & 1 & 631 & $8,00 \mathrm{E}-13$ & $\begin{array}{l}\text { putative HlyD family secretion protein } \\
\text { [Bordetella parapertussis 12822] }\end{array}$ & NCBI \\
\hline
\end{tabular}


Anexo 6 - Similaridades de ESTs obtidas a partir de raízes de cana-de-açúcar não-inoculadas e adubadas 200mg $\mathrm{P} \mathrm{kg}^{-1}$ com os bancos de dados NCBI ou SUCEST.

(conclusão)

\begin{tabular}{|c|c|c|c|c|c|}
\hline Cluster & Read & Tamanho & E-value & Blast & Base \\
\hline SCESMY4003E01.g & 1 & 289 & $1,00 \mathrm{E}-12$ & $\begin{array}{l}\text { L-alanine-DL-glutamate epimerase and related } \\
\text { enzymes of enolase superfamily [Burkholderia } \\
\text { cepacia R18194] }\end{array}$ & NCBI \\
\hline SCESMY4003E02.g & 1 & 760 & $1,00 \mathrm{E}-142$ & F21B7.1 [Arabidopsis thaliana]" & SUCEST \\
\hline SCESMY4003E03.g & 1 & 660 & 1,00E-11 & $\begin{array}{l}\text { Glycosyltransferases, probably involved in cell } \\
\text { wall biogenesis [Pseudomonas fluorescens PfO- } \\
\text { 1] }\end{array}$ & NCBI \\
\hline SCESMY4003E04.g & 1 & 696 & $6,00 \mathrm{E}-11$ & $\begin{array}{l}\text { Fe2+-dicitrate sensor, membrane component } \\
\text { [Pseudomonas fluorescens PfO-1] }\end{array}$ & NCBI \\
\hline SCESMY4003F02.g & 1 & 686 & $6,00 \mathrm{E}-10$ & EaaA [prophage P-EibA] & NCBI \\
\hline SCESMY4003F03.g & 1 & 712 & 5,00E-09 & $\begin{array}{l}\text { NADH dehydrogenase I subunit G } \\
\text { [Pseudomonas fluorescens }\end{array}$ & NCBI \\
\hline SCESMY4003F04.g & 1 & 563 & $1,00 \mathrm{E}-148$ & metallothionein $2 b$ & SUCEST \\
\hline SCESMY4003F05.g & 1 & 737 & 2,00E-07 & $\begin{array}{l}\text { glucokinase [Escherichia coli O157:H7 } \\
\text { EDL933] }\end{array}$ & NCBI \\
\hline SCESMY4003G01.g & 1 & 401 & $7,00 \mathrm{E}-07$ & $\begin{array}{l}\text { ferric alcaligin siderophore receptor [Bordetella } \\
\text { pertussis Tohama I] }\end{array}$ & NCBI \\
\hline SCESMY4003G02.g & 1 & 691 & $1,00 \mathrm{E}-156$ & $\begin{array}{l}\text { contains ESTs } \\
\text { AU029689(EE1266),C91697(EE1266) unknow } \\
\text { n protein [Oryza sativa]" }\end{array}$ & SUCEST \\
\hline SCESMY4003G03.g & 1 & 708 & $1,00 \mathrm{E}-134$ & $\begin{array}{l}\text { Permeases of the major facilitator superfamily } \\
\text { [Pseudomonas fluorescens PfO-1] }\end{array}$ & NCBI \\
\hline SCESMY4003G04.g & 1 & 700 & $1,00 \mathrm{E}-162$ & $\begin{array}{l}\text { ligand-gated channel-like protein precursor } \\
\text { [imported] - Arabidopsis thaliana }\end{array}$ & SUCEST \\
\hline SCESMY4003H05.g & 1 & 464 & $1,00 \mathrm{E}-165$ & high pI alpha-glucosidase [Hordeum vulgare]" & SUCEST \\
\hline
\end{tabular}

